\title{
Morphological and Phylogenetic Resolution of Diplodia spp., Emerging Canker Pathogens of Oak (Quercus spp.), in the United States
}

Savannah Lyn Ferreira

WVU, slh0066@mix.wvu.edu

Follow this and additional works at: https://researchrepository.wvu.edu/etd

Part of the Plant Pathology Commons

\footnotetext{
Recommended Citation

Ferreira, Savannah Lyn, "Morphological and Phylogenetic Resolution of Diplodia spp., Emerging Canker Pathogens of Oak (Quercus spp.), in the United States" (2019). Graduate Theses, Dissertations, and Problem Reports. 7457.

https://researchrepository.wvu.edu/etd/7457

This Thesis is protected by copyright and/or related rights. It has been brought to you by the The Research Repository @ WVU with permission from the rights-holder(s). You are free to use this Thesis in any way that is permitted by the copyright and related rights legislation that applies to your use. For other uses you must obtain permission from the rights-holder(s) directly, unless additional rights are indicated by a Creative Commons license in the record and/ or on the work itself. This Thesis has been accepted for inclusion in WVU Graduate Theses, Dissertations, and Problem Reports collection by an authorized administrator of The Research Repository @ WVU. For more information, please contact researchrepository@mail.wvu.edu.
} 
Morphological and Phylogenetic Resolution of Diplodia spp., Emerging Canker Pathogens of Oak (Quercus spp.), in the United States

\author{
Savannah Lyn Ferreira
}

Thesis submitted to the Davis College of Agriculture, Natural Resources and Design at West

Virginia University in partial fulfillment of the requirements for the degree of

Master of Science

In

Plant Pathology

Matthew Kasson, Ph.D., Chair

Amy Hessl Ph.D.

Danielle K. Martin, M.S.

Daniel Panaccione, Ph.D.

Division of Plant and Soil Sciences

Morgantown, West Virginia

2019

Keywords: Diplodia corticola, Diplodia quercivora, Quercus rubra, Quercus alba, Quercus montana, Oak Decline

Copyright 2019 Savannah Lyn Ferreira 


\begin{abstract}
Morphological and Phylogenetic Resolution of Diplodia spp., Emerging Canker Pathogens of Oak (Quercus spp.), in the United States
\end{abstract}

\author{
Savannah Lyn Ferreira
}

In Mediterranean Europe and the United States, oak species (Quercus spp.) have been in a state of declining health and vigor for the past several decades. Several biotic agents have been found to contribute to this decline to varying degrees including Phytophthora cinnamomi and Armillaria spp., both causal agents of root rots, and various insect defoliators. In the U.S., Bretziella fagacearum, the causal agent of oak wilt, has also been implicated. More recently, Diplodia corticola $(D c)$ and other Diplodia spp. have been implicated in causing dieback and mortality of oak species in Europe and in several regions in the United States. In an attempt to determine the origin(s) of $D c$ and whether it can be considered an introduced pathogen in the U.S., a phylogenetic study and associated morphological studies were conducted to resolve relationships among $D c$ isolates from geographically discrete populations in both Europe and the U.S. A total of 23 Diplodia isolates from Spain, France, Italy and the U.S. were studied, including 20 previously ITS barcoded $D c$ isolates, two $D q$ isolates, and one D. mutila (Dm) isolate. Many of these isolates had been previously included in pathogenicity tests. Across all isolates and geographic regions, $D c$ formed a strongly supported clade sister to $D q$ and included two subclades, one that included isolates from Spain and California and a second that included isolates from Italy and West Virginia. Both subclades had moderate bootstrap support. The Spain and California isolates also exhibited overlapping culture morphology and spore measurements, but larger trends based on these morphological features across $D c$ were not consistent or phylogenetically informative. The results of this study offer support for $D c$ as a cosmopolitan pathogen, native to both Europe and the U.S. Concurrent to investigations between European and U.S. Diplodia populations, a study was initiated to determine the range and impact of $D c$ and $D q$ on forest health within the U.S. To this end, a fungal survey was conducted in the Mid-Atlantic region, including Maryland, Pennsylvania, Virginia and West Virginia in 2019. A total of 563 oak species between red and white oak family members were evaluated across 33 forests spanning 18 counties. A total of 32 Diplodia isolates encompassing three Diplodia spp. were recovered out of some 5,335 total plugs sampled from the 18 sampled counties. Diplodia species recovered included $D c, D q$, and $D$. sapinea $(D s)$, as well as Botryosphaeria dothidea $(B d)$, another close relative in the Botryosphaeriaceae. Both $D c$ and $D s$ were recovered from red and white oak family members, whereas $D q$ was exclusive to white oak family members and $B d$ to red oak family members. Of these species $D c$ was most frequently isolated followed by $D q, D s$, and $B d$. Overall, mortality was relatively low across all sampled counties, indicating that these fungi, at the levels that were detected, are not widely inciting oak decline across the region but more likely are acting opportunistically when the environment is favorable. 


\section{Acknowledgements:}

This has been a challenging and fulfilling experience and I am grateful to have had the opportunity to pursue my studies at this university. I have been passionate about trees and tree health care for many years and knew since high school that this was a career path I wanted to pursue. I would like to first thank my undergraduate academic advisor, Dr. William Livingston at the University of Maine, for being the first professional who saw the future pathologist in me. Working in his lab opened my eyes to the possibilities and opportunities a forest health career can provide, and with his help I was able to shape my education in a way that would lead to me those opportunities.

I am also grateful for the opportunity to pursue a research assistantship at West Virginia University under Dr. Matthew Kasson, and work on such a fun and complex project. Working in the Kasson Lab is a full of spontaneous adventures and rarely has a dull day. Thank you for always challenging me and helping me to develop into a well-rounded pathologist. I would also like to thank the remainder of my committee, Danielle Martin, who has been a very active member of my project and who has helped me grow professionally, Dr. Daniel Panaccione, a wonderful teacher and mentor who goes above and beyond to help students both academically and professionally, and Dr. Amy Hessel, who has been resourceful and supportive throughout the project.

I would like to thank my husband, Blake, for all his help and support throughout my career. Additionally, I would like to thank him for his help in the field this past summer, without him, my sampling would have taken a lot longer and would have been a lot less fun. Lastly I would like to thank my parents and my in-laws for their support and understanding in pursuing an uncommon profession and letting me follow my dreams. Thank you for always believing in me. 
Dedication:

To my husband,

You have been my rock and source of strength for the duration of my education. Thank you for your unwavering love, support and patience throughout my career. 


\section{Table of Contents}

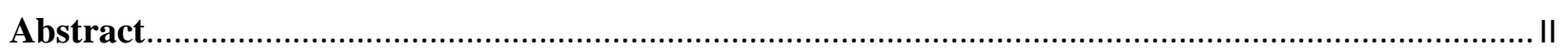

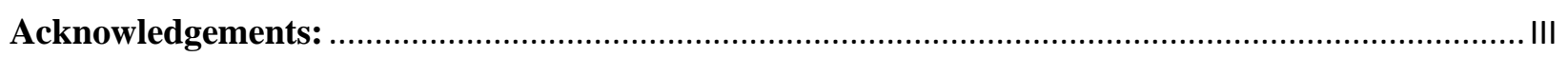

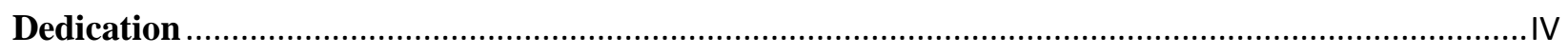

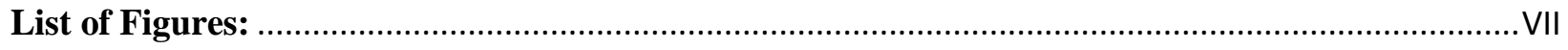

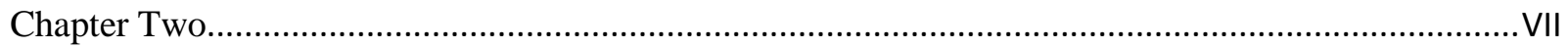

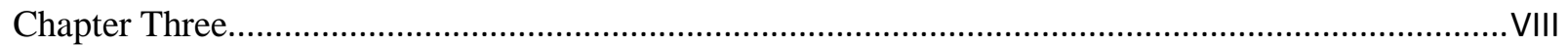

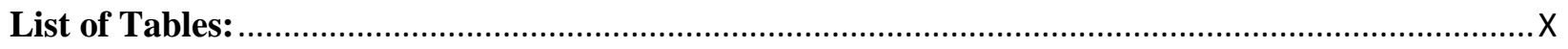

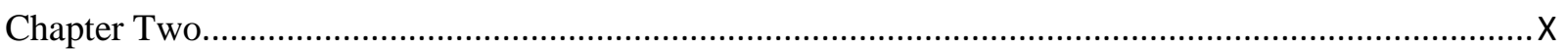

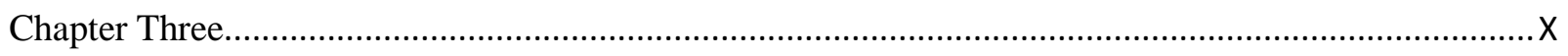

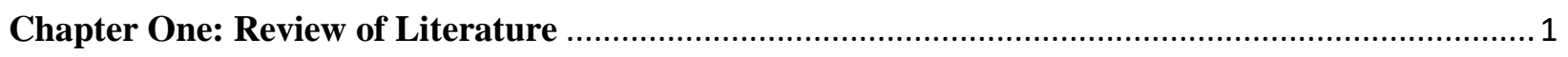

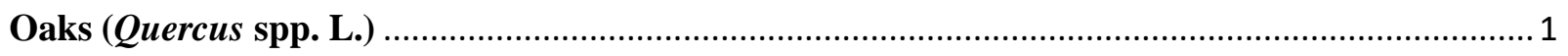

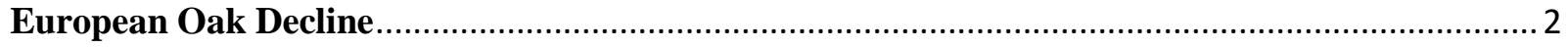

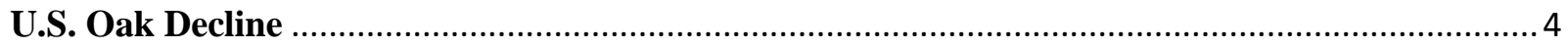

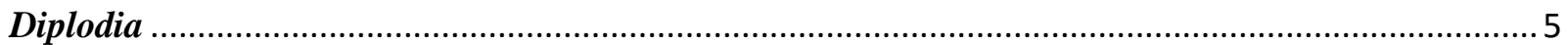

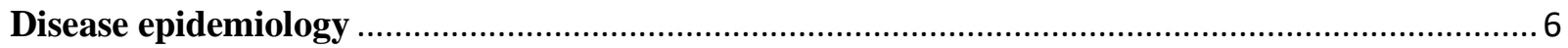

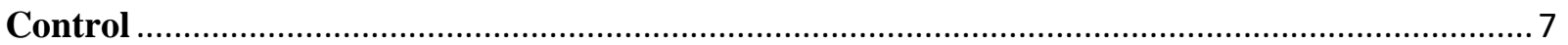

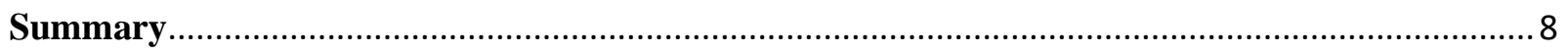

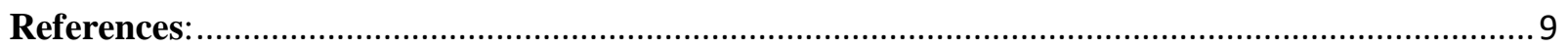

Chapter Two: Global Comparisons Among Diplodia corticola Affecting Oak Species .....................14

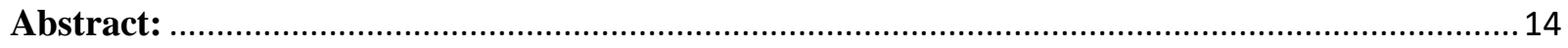

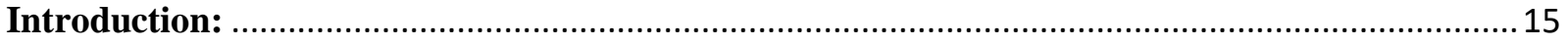

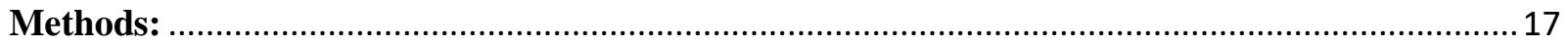

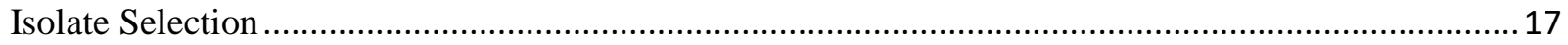

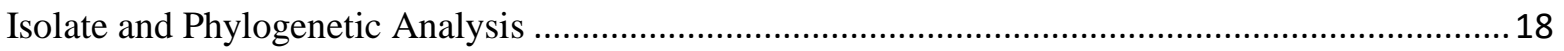

Spore Production and Associated Measurements ..................................................................... 21

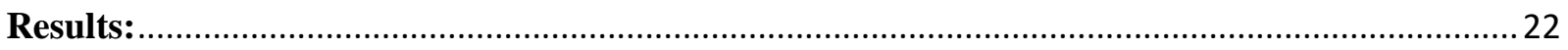

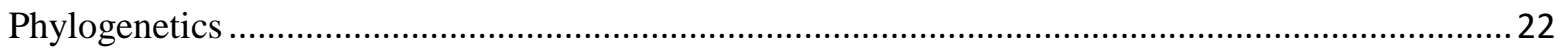

Spore Production and Associated Measurements …......................................................................2 27

Colony Morphology On Specialized Media ……........................................................................... 31

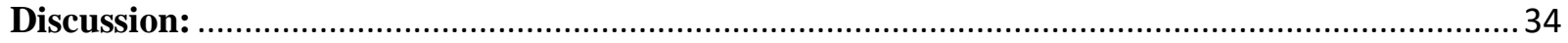

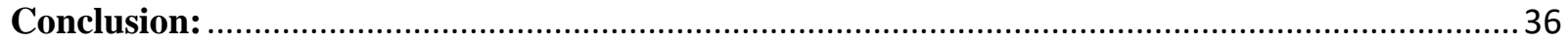




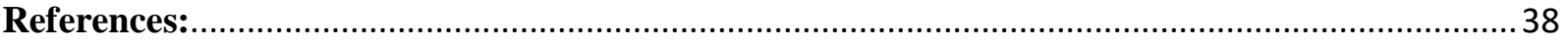

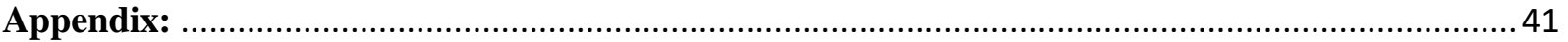

Chapter Three: Geographic, Morphological and Phylogenetic Distribution of Diplodia spp. In Oak

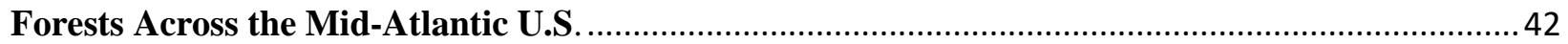

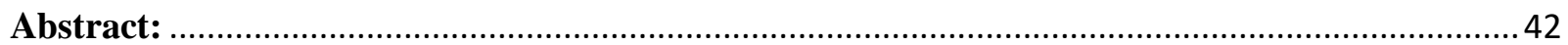

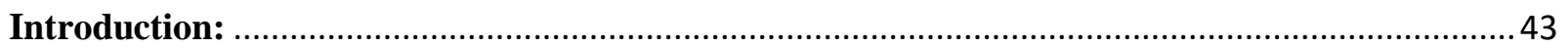

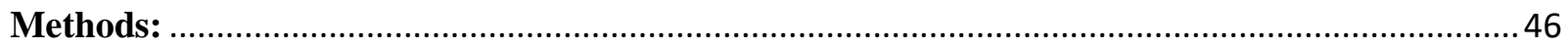

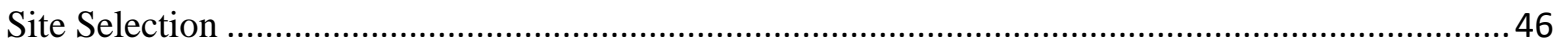

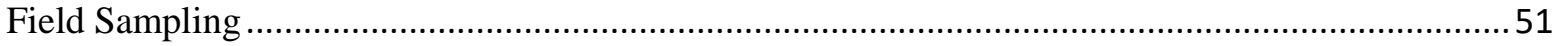

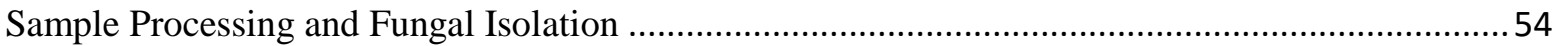

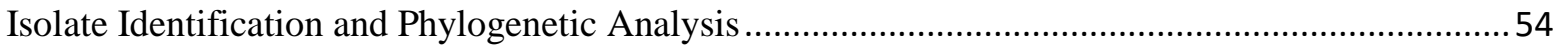

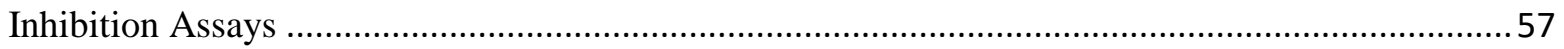

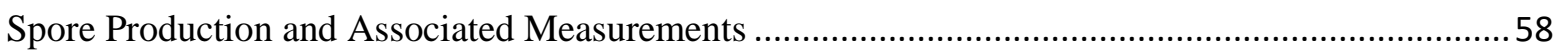

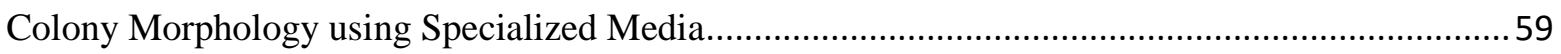

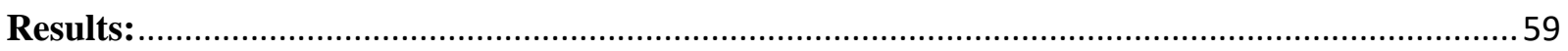

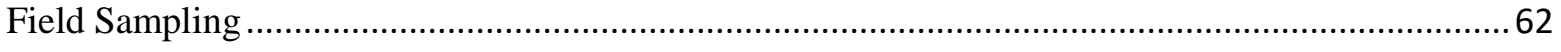

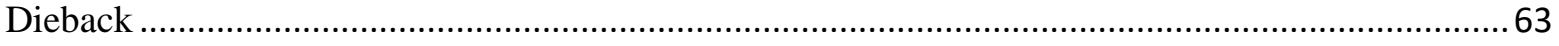

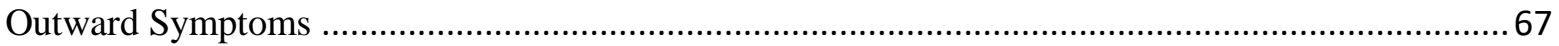

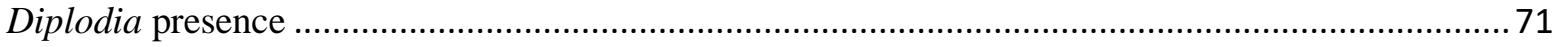

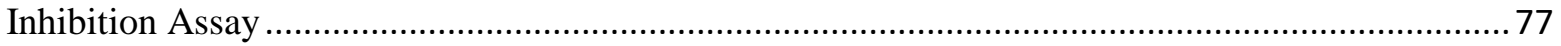

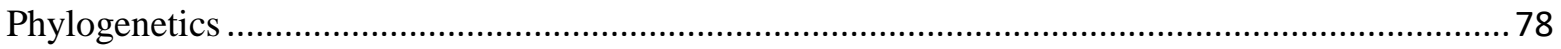

Spore Production and Associated Measurements ................................................................... 84

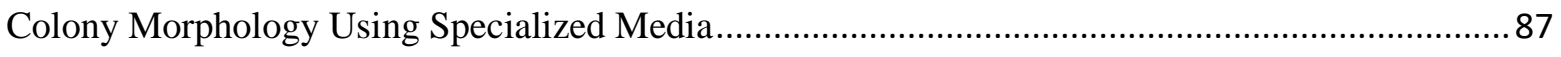

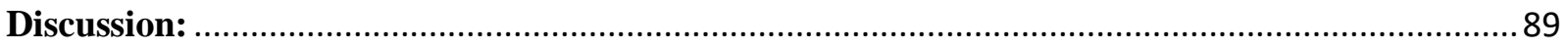

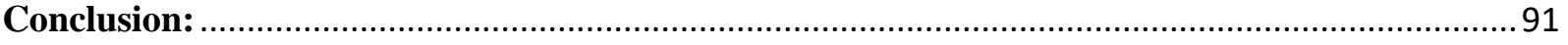

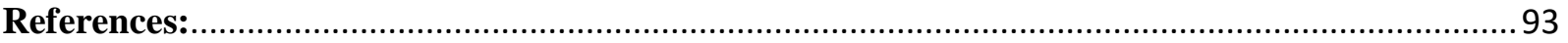




\section{List of Figures:}

\section{Chapter Two}

Figure 1: Phylogenetic tree showing the three-gene concatenated gene regions comprising ITS, EF- $1 \alpha$ and LSU for 19 analyzed isolates. For maximum likelihood analyses, a best fitting model was chosen using Model Selection analysis and 1,000 bootstrap replicates were used with the best tree being identified and bootstrapped in a single run.

Figure 2: Phylogenetic tree showing ITS gene region for 19 analyzed isolates. For maximum likelihood analyses, a best fitting model was chosen using Model Selection analysis and 1,000 bootstrap replicates were used with the best tree being identified and bootstrapped in a single run.

Figure 3: Phylogenetic tree showing EF-1 $\alpha$ gene region for 19 analyzed isolates. For maximum likelihood analyses, a best fitting model was chosen using Model Selection analysis and 1,000 bootstrap replicates were used with the best tree being identified and bootstrapped in a single run.

Figure 4: Phylogenetic tree showing LSU gene region for 19 analyzed isolates. For maximum likelihood analyses, a best fitting model was chosen using Model Selection analysis and 1,000 bootstrap replicates were used with the best tree being identified and bootstrapped in a single run.

Figure 5: A) $D c$ isolate growing on GYEA, B) $D c$ isolate developing pycnidia precursors on $\left.1 / 10^{\text {th }} \mathrm{GYE}, \mathrm{C}\right) D c$ isolate exuding conidia from numerous pycnidia on $1 / 10^{\text {th }} \mathrm{GYE}$, D) Conidial tendril being exuded from pycnidia, E) Mass of conidia being exuded from pycnidia, F) Mass of brown septate conidia.

Figure 6: Morphological comparison of spores from $D c$ from A) CA, B) FL, C) WV, D) Italy, E) $D m$ from France; F) $D q$ from MA. Mountant is lactophenol + cotton blue. Spores shown at $40 \mathrm{X}$ magnification, not to scale.

Figure 7: Box plots for average spore size ((Length One + Length Two)/2) of $D c$ isolates $(\mathrm{N}=$ 19) by location (state where isolate was retained from: CA $(n=3)$, FL $(n=3)$, Italy $(n=1)$, MA $(n=2), \operatorname{ME}(n=2)$, Spain $(n=5)$, WI $(n=1)$, and WV $(n=2)$. Spore sizes compared between species and among geographic location using ANOVA. Letter designation by Tukey Kramer's ordered letter report shows significant differences by location. Single points outside the upper and lower extremes represent outliers and were included in analysis.

Figure 8: Box plots for average spore size ((Length One + Length Two)/2) of $D q$ isolates $(\mathrm{N}=2)$ by location (state where isolate was retained from: MA: $(n=1)$ and MD: $(n=1)$. Spore sizes compared between species and geographical location using ANOVA. Letter designation by Tukey Kramer's ordered letter report shows significant differences by location. Single points outside the upper and lower extremes represent outliers and were included in analysis....

Figure 9: Diplodia spp. isolates grown on pine needle extract agar for two weeks. $D c$ morphology: A) morphotype 1, B) morphotype 2, C) morphotype 3, D) morphotype 4, E) morphotype 5; $D q$ morphology: F) morphotype 1 
Figure 10: Diplodia spp. isolates grown on pine needle extract agar for two weeks. $D c$ morphology: A) morphotype 6, B) morphotype 7, C) morphotype 8, D) morphotype 9, E) morphotype 10, F) morphotype 11, G) morphotype 12; Dq morphology: H) morphotype 1, I) morphotype 2 .

\section{Chapter Three}

Figure 1: Oak Mortlity Summer Sampling 2019 Map. Colored counties represent each \% Mortality level of intrest (blue: < $1 \%$ mortality, green: 1.1-2.5\% mortality, yellow: $2.6-5 \%$ mortality and red: $5-17.4 \%$ mortality in the four selected states (MD, PA, WV, VA)) in the lower Mid-Atlantic Region.

Figure 2: Sample map depicting field plots for Beech Fork Wildlife Management Area in Wayne County, WV.

Figure 3: Progression of dieback in sampled oaks: A) 0-24\%, B) 25-49\%, C) 50-74\%, D) 75 $99 \%$, E) $100 \%$ 52

Figure 4: Examples of symptomatic tissue that would be sampled for Diplodia spp. infection. AB) Sooty lesions C-D) External cankers.

Figure 5: Oak Mortlity Summer Sampling 2019 Map showing Diplodia positive counties ( $\mathrm{n}=$ 13).

Figure 6: Mosaic plot comparing incidence of red oak family members $(n=191)$ to white oak family members $(n=372)$ observed during this study.

Figure 7: Mosaic plot comparing red oak family dieback to white oak family dieback. Data are separated by \%dieback $(1: 0-24 \%$ dieback $(n=403)), 2: 25-49 \%$ dieback $(n=99), 3: 50-74 \%$ dieback $(\mathrm{n}=20), 4: 75-99 \%$ dieback $(\mathrm{n}=10)$ and 5: 100\% dieback (dead) $(\mathrm{n}=31)$ and oak family $(\mathrm{RO}=$ red oak family members $(\mathrm{n}=191), \mathrm{WO}=$ white oak family members $(\mathrm{n}=372)) .63$ Figure 8: Mosaic plot showing \%dieback vs. canopy class. Data are separated by \%dieback (1: 0$24 \%$ dieback $(n=403)), 2: 25-49 \%$ dieback $(n=99), 3: 50-74 \%$ dieback $(n=20), 4: 75-99 \%$ dieback $(\mathrm{n}=10)$ and $5: 100 \%$ dieback $(\mathrm{dead})(\mathrm{n}=31))$ and canopy class $(\mathrm{CD}=$ codominant $(\mathrm{n}=$ 373), $\mathrm{D}=$ dominant $(\mathrm{n}=79), \mathrm{I}=$ intermediate $(\mathrm{n}=72), \mathrm{NA}=$ not applicable because it is so dead $(\mathrm{n}=16), \mathrm{U}=$ understory $(\mathrm{n}=23))$.

Figure 9: Mosaic plot showing \%dieback vs. symptom class. Data are separated by \%dieback (1: $0-24 \%$ dieback $(n=403)), 2: 25-49 \%$ dieback $(n=99), 3: 50-74 \%$ dieback $(n=20), 4: 75-99 \%$ dieback $(\mathrm{n}=10)$ and $5: 100 \%$ dieback $(\mathrm{dead})(\mathrm{n}=31))$ and symptom class $(0=$ no outward symptoms $(n=391), 1=1-3$ visible cankers $(n=124), 2=4-6$ visible cankers $(n=26), 3=7-9$ visible cankers $(n=3), 4=$ more than 9 visible cankers $(n=7), N A=$ not applicable because it is so dead $(\mathrm{n}=12))$.

Figure 10: Mosaic plot showing symptom class vs. oak family. Data are separated by symptom class $(0=$ no outward symptoms $(n=391), 1=1-3$ visible cankers $(n=124), 2=4-6$ visible cankers $(n=26), 3=7-9$ visible cankers $(n=3), 4=$ more than 9 visible cankers $(n=7), N A=$ not applicable because it is so dead $(\mathrm{n}=12)$ and oak family $(\mathrm{RO}=$ red oak family members $(\mathrm{n}=$ $191), \mathrm{WO}=$ white oak family members $(\mathrm{n}=372)$ ). 
Figure 11: Mosaic plot showing Diplodia presence vs. oak family. Data are separated by symptom class $(0=$ Diplodia negative $(\mathrm{n}=986), 1=$ Diplodia positive $(\mathrm{n}=28))$ and oak family $(\mathrm{RO}=$ red oak family members $(\mathrm{n}=191), \mathrm{WO}=$ white oak family members $(\mathrm{n}=372))$. 73 Figure 12: Mosaic plot showing Diplodia species vs. oak family. Data are separated by Diplodia species $(B d=$ Botryosphaeria dothidea $(\mathrm{n}=1)$, Dc $=$ Diplodia corticola $(\mathrm{n}=18)$, D $q=$ Diplodia quercivora $(\mathrm{n}=6)$, Ds $=$ Diplodia sapinea $(\mathrm{n}=3))$ oak family $(\mathrm{RO}=$ red oak family members $(\mathrm{n}$ $=191)$, WO = white oak family members $(n=372)$ ). 75 Figure 13: Initial fungal inhibition assay. A) Inhibition of $D q$ by Penicillium, B \&E ) Inhibition of Trichoderma by $D c$, C) Tie between Dc and Pestalotiopsis, D) Inhibition of Dc by Penicillium, F) Inhibition of $D c$ by Pestalotiopsis. 77

Figure 14: Follow-up fungal inhabition assay. A - C) Inhibition of Dc by Pestalotiopsis, D \&E) Inhibition of $D q$ by Penicillium, F) Inhibition of $B d$ by Penicillium................................... 78 Figure 15: Phylogenetic tree showing ITS, EF-1 $\alpha$ and LSU gene regions for 35 analyzed isolates. For maximum likelihood analyses, a best fitting model was chosen using Model Selection analysis and 1,000 bootstrap replicates were used with the best tree being identified and bootstrapped in a single run.

Figure 16: Phylogenetic tree showing ITS gene region for 35 analyzed isolates. For maximum likelihood analyses, a best fitting model was chosen using Model Selection analysis and 1,000 bootstrap replicates were used with the best tree being identified and bootstrapped in a single run.

Figure 17: Phylogenetic tree showing EF-1 $\alpha$ gene region for 35 analyzed isolates. For maximum likelihood analyses, a best fitting model was chosen using Model Selection analysis and 1,000 bootstrap replicates were used with the best tree being identified and bootstrapped in a single run.

Figure 18: Phylogenetic tree showing LSU gene region for 35 analyzed isolates. For maximum likelihood analyses, a best fitting model was chosen using Model Selection analysis and 1,000 bootstrap replicates were used with the best tree being identified and bootstrapped in a single run.

Figure 19: Morphological comparison of spores from $D c$ from A) MD, B) PA, C) VA and D) WV; $D q$ from E) MD; $D s$ from F) PA and G) WV; $B d$ from H) WV. Mountant is lactophenol + cotton blue. Spores shown at 40X magnification, not to scale. Figure 20: Box plots for average spore size ((Length One + Length Two $) / 2)$ of $D s$ isolates $(\mathrm{N}=$ $75)$ by location (state where isolate was obtained from PA $(n=2)$ and WV $(n=1))$. Spore sizes compared between species and among geographic location using ANOVA. Letter designation by Tukey Kramer's ordered letter report shows significant differences by location.... 85 Figure 21: Box plots for average spore size ((Length One + Length Two)/2) of $D c(\mathrm{~N}=500)$ isolates by location (state where isolate was retained from MD $(n=4)$, PA $(n=7)$, VA $(n=6)$ and WV $(n=3)$. Spore sizes compared between species and among geographic location using ANOVA. Letter designation by Tukey Kramer's ordered letter report shows significant differences by location. Single points outside the upper and lower extremes represent outliers and were included in analysis. 86

Figure 22: Representative Diplodia spp. isolates grown on pine needle extract agar for two weeks. $D c$ morphology A) morphotype 1, B) morphotype 2, C) morphotype 3, D) morphotype 4, 
E) morphotype 5, F) morphotype 6, G) morphotype 7, H) morphotype 8; $D q$ morphology I) morphotype 1; Ds morphology J) morphotype 1, K) morphotype 2, L) morphotype 3; $B d$ morphology M) morphotype 1 .

\section{List of Tables:}

\section{Chapter Two}

Table 1: Isolate name and location of selected Diplodia spp.

Chapter Two Appendix

Table 1: Isolate name and associated GenBank gene ID:

\section{Chapter Three}

Table 1: Sampled locations per county and mortality level for each state. 49

Table 2: Forests and location of recovered Diplodia spp.

Table 3: Summary statistics for dieback rating by family for all oberved oak trees. Data are separated by \%dieback $(1: 0-24 \%$ dieback $(n=403)), 2: 25-49 \%$ dieback $(n=99), 3: 50-74 \%$ dieback $(n=20), 4: 75-99 \%$ dieback $(n=10)$ and 5: 100\% dieback (dead) $(n=31))$ and oak family $(\mathrm{RO}=$ red oak family members $(\mathrm{n}=191), \mathrm{WO}=$ white oak family members $(\mathrm{n}=372)) .64$ Table 4: Summary statistics for dieback rating by canopy class for all oberved oak trees. Data are separated by \%dieback $(1: 0-24 \%$ dieback $(n=403)), 2: 25-49 \%$ dieback $(n=99), 3: 50-74 \%$ dieback $(n=20), 4: 75-99 \%$ dieback $(n=10)$ and 5: $100 \%$ dieback (dead) $(n=31))$ and canopy class $(C D=$ codominant $(n=373), D=$ dominant $(n=79), I=$ intermediate $(n=72), N A=$ not applicable because it is so dead $(n=16), U=$ understory $(n=23))$.

Table 5: Summary statistics for dieback rating by symptom class for all observed oak trees. Data are separated by \%dieback $(1: 0-24 \%$ dieback $(\mathrm{n}=403)), 2: 25-49 \%$ dieback $(\mathrm{n}=99), 3: 50-74 \%$ dieback $(n=20), 4: 75-99 \%$ dieback $(n=10)$ and 5: 100\% dieback $($ dead $)(n=31))$ and symptom class $(0=$ no outward symptoms $(n=391), 1=1-3$ visible cankers $(n=124), 2=4-6$ visible cankers $(n=26), 3=7-9$ visible cankers $(n=3), 4=$ more than 9 visible cankers $(n=7)$, $\mathrm{NA}=$ not applicable because it is so dead $(\mathrm{n}=12))$.

Table 6: Summary statistics for symptom class by oak family. Data are separated by symptom class $(0=$ no outward symptoms $(n=391), 1=1-3$ visible cankers $(n=124), 2=4-6$ visible cankers $(n=26), 3=7-9$ visible cankers $(n=3), 4=$ more than 9 visible cankers $(n=7), N A=$ not applicable because it is so dead $(\mathrm{n}=12)$ and oak family $(\mathrm{RO}=$ red oak family members $(\mathrm{n}=$

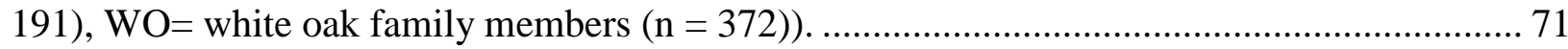

Table 7: Forests locations and host data for recovered Diplodia spp. 72 Table 8: Summary statistics for Diplodia presence by oak family. Data are separated by symptom class $(0=$ Diplodia negative $(\mathrm{n}=986), 1=$ Diplodia positive $(\mathrm{n}=28))$ and oak family $(\mathrm{RO}=$ red oak family members $(\mathrm{n}=191), \mathrm{WO}=$ white oak family members $(\mathrm{n}=372))$ 
Table 9: Summary statistics for Diplodia species by family for all Diplodia positive oak trees. Data are separated by Diplodia species $(B d=$ Botryosphaeria dothidea $(\mathrm{n}=1)$, Dc $=$ Diplodia corticola $(\mathrm{n}=18), D q=$ Diplodia quercivora $(\mathrm{n}=6)$, Ds = Diplodia sapinea $(\mathrm{n}=3))$ oak family $(\mathrm{RO}=$ red oak family members $(\mathrm{n}=191), \mathrm{WO}=$ white oak family members $(\mathrm{n}=372)) \ldots \ldots \ldots \ldots . . . .75$ 


\section{Chapter One: Review of Literature}

\section{Oaks (Quercus spp. L.)}

Quercus spp., commonly known as oak, is an economically and ecologically important genus in the beech family (Fagaceae) comprising over 600 species in six continents between the northern temperate and tropical zones (Nixion 2006, Abrams 1996). Quercus spp. include both deciduous and evergreen species and are colloquially broken down into three subgroups: Leucobalanus (white oak family), Erythrobalanus (red oak family) and Cerris (neither red or white family) (Denk et al. 2017).

White oak family members consist of lighter barked trees with smooth and roundedlobed leaves, while red oak family members have darker bark and have lobbed leaves that are pointed at the tip (Rodger 1990, Sander 1990). The subgroup Cerris has been disputed taxonomically since 1838 , with reclassifications being conducted with new species observations (Denk et al. 2017). This subgroup was previously classified as Cyclobalanus (1993) but has since changed to Cerris containing species such Q. cerris (Austrian oak) and Q. ilex (evergreen oak) (Denk et al. 2017). The Cerris subgroup is only separated morphologically from the other two families by the concentric rings formed by the scales of the acorns whereas both red and white oak family members have scales spirally arranged (Cannon 2001).

Red oak family members are valued commercially for lumber and used in furniture making and flooring while white oak family members are valued for wine and bourbon barrels and cork manufacturing (Coltswold 2019, Meier 2008). Oak species are also valued ecologically as an important source of mast production in many regions. Acorns are consumed by numerous 
wildlife species including squirrels, mice, birds, deer and bears and can directly affect weight, health, and population dynamics of these species (Brose et al. 2018, Stolte 2012). In addition to being a food source, oak species aid in providing ecosystem services including water filtration, oxygen production, carbon sequestration and air filtration (Cavender-Bares 2016).

\section{European Oak Decline}

Oak trees (Quercus spp.) in the Mediterranean region of Europe have been in a state of decline for the last several decades, with a notable increase in mortality beginning in the $1980 \mathrm{~s}$ (da Clara and de Ribeiro 2013, Linaldeddu et al. 2014, Alves et al. 2004). Initial reports of decline including dieback and decreased tree health and vigor were incorrectly attributed to several species of Diplodia including D. mutila, D. quercina, D. quercuum and D. stevensii, which have since been confirmed as Diplodia corticola $(D c)$, the anamorph state of Botryosphaeria corticola (Alves et al. 2004).

Following its reclassification, $D c$ has been documented causing disease on cork oak $(Q$. suber), evergreen oak (Q. ilex), sessile oak (Q. petraea) and turkey oak (Q. cerris) in Portugal, Spain, Italy and France (Linaldeddu et al. 2017, Lazzizera et al. 2008, Alves et al. 2004). Oak trees in this region are valued commercially for lumber and used in furniture making, wine and bourbon barrel manufacturing, and cork production (Coltswold 2019, Meier 2008). The harvesting of cork oak bark for wine corks (Coltswold 2019, Meier 2008) can put cork oak trees at increased risk of opportunistic infection due to inflicted mechanical damage when harvesting the bark (Cork Forest Conservation Alliance 2015).

In addition to $D c$, European oak decline has also been contributed with abiotic complexes including drought and flooding (Linaldeddu et al. 2014, Alves et al. 2004, Brasier and Scott 
1994) as well as biotic agents such as Phytophthora cinnamomi (Keča et al. 2016, Linaldeddu et al. 2014, da Clara and de Ribeiro 2013), Armillaria spp. and various insect defoliators (Keča et al. 2016).

Mediterranean Europe is a hot spot of climate change symptoms, experiencing increased temperatures and extreme climatic events (Moricca et al. 2016, Sturrock et al. 2011). Severe and changing weather events negatively impact overall tree health and vigor, which can predispose a tree to various insect or fungal infections (Moricca et al, 2016, Sturrock et al. 2011) such as $D c$, Phytophthora spp. and/or Armillaria spp.

Phytophthora cinnamomi has been implicated in dieback and mortality throughout Europe since the early 1900s (Moricca et al, 2016) with more recent identification of $P$. quercina, P. gonapodyides and P. psychrophila (Moricca et al. 2016, Linaldeddu et al. 2014, Pérez-Sierra et al. 2013). These soil borne oomycetes are invasive and cause root rot in a broad range of hosts, leading to severe dieback and mortality (Linaldeddu et al. 2014). Armillaria, a root rot fungus, acts opportunistically in areas of biotic and abiotic stressors causing dieback and mortality of a wide range of woody hosts (Gerlach et al.1997, Raabe 1962).

Although often found in association with each other, few studies have been conducted on the interaction of these biotic and abiotic factors with $D c$. Linaldeddu and colleagues (2014) conducted sampling assays in roots and soil for Phytophthora spp. presence in Italy, leading to the observation of $D c$ as a root pathogen in the area. Pathogenicity tests of several Diplodia spp., including $D c$, along with several Phytophthora spp. including P. cinnamomi, were conducted as part of their study, however the interaction of them together was not evaluated. 


\section{U.S. Oak Decline}

In the United States, oak species have also been in a in a state of declining health and vigor for the past several decades, although the distribution of the decline is heterogeneous across the landscape (Oak et al. 2016). Detections of $D c$ were reported causing disease in coastal live oak (Quercus agrifolia), red oak (Q. rubra), black oak (Q. velutina), bur oak ( $Q$. macrocarpa), southern live oak (Q. virginiana), and white oak $(Q . a l b a)$ in Washington D.C. (Smith and Stanosz 2018) and eight U.S. states (Reed et al. 2018, Smith and Santosz 2018, Martin et al. 2017, Munck et al. 2017, Martin and Munck 2017, Aćimović et al. 2016, Dreaden et a. 2011, Lynch et al. 2010). Other biotic organisms that have been classified as part of this decline include Bretziella fagacearum, the causal agent of oak wilt (MacDonald et al. 2001, Jacobi and MacDonald 1980, Amos and True 1967, Shigo 1958), Phytophthora cinnamomi, causal agent of Phytophthora root rot (McConnell and Balci 2014), and various insect defoliators including gypsy moth (Lymantria dispar) and the goldspotted oak borer (Agrilus auroguttatus) (Tiberi et al. 2016, Asaro and Chamberlin 2015, Lynch et al. 2010).

Bretziella fagacearum has been implicated in dieback and disease across the U.S. since the early 1940s (Munck 2017, Juzwik et al. 2011). This vascular wilt disease causes leaf wilt, early leaf drop, crown dieback, bole epicormic growth and seemingly sudden mortality of red oak family members (Munck 2017, Juzwik et al. 2011, MacDonald et al. 2001, Jacobi and MacDonald 1980). In white oak family members, this pathogen shows similar symptoms, however the decline to mortality is more gradual and less common (Juzwik et al. 2011). When $B$. fagacearum penetrates the vascular cambium, trees respond in three tandem directions, vertically, radially and tangentially to wall off and stop the spread of the pathogen (Shortle 1979). White oak family members may be responding faster to oak wilt infections due to the 
utilization of tyloses during compartmentalization, which acts as an additional response in the vascular tissue (De Micco et al 2016, Meier 2008). Given the historic incidence of oak wilt in the eastern U.S. and that some symptoms of both Diplodia and oak wilt overlap, it is possible that Diplodia was previously overlooked and mistaken for oak wilt.

Phytophthora cinnamomi, a contributing factor to oak decline in Europe, has also been implicated in causing dieback and disease of oak throughout the U.S. (McConnell and Balci 2014, Hansen 2003). The southeastern U.S. has had the longest history of documented damage from Phytophthora spp., with more recent reports of damage in the western U.S. (Hansen 2003). Similar to European strains, Phytophthora spp. are virulent pathogens with broad host ranges and have been implicated in broad-scale oak decline (Linaldeddu et al. 2014, Gerlach et al.1997, Raabe 1962).

Another recent decline described as Rapid White Oak Mortality has been implicated in contemporary oak decline in several states in the U.S. and has been found to involve both $B$. fagacearum and Phytophthora spp. (Reed et al. 2017), although other contributing biotic agents are likely involved but have yet to be identified. Due to oak decline's history of other prevalent biotic complexes in both Europe and the U.S., it is possible that Diplodia spp. have been overlooked as possible contributor to this decline.

\section{Diplodia}

Diplodia corticola, the anamorph state of Botryosphaeria corticola, is a cosmopolitan fungal canker pathogen of oak trees (Quercus spp.) (Martin et al. 2017, Munck et al. 2017, Aćimović et al. 2016, Linaldeddu et al. 2014, Dreaden et al. 2011, Alves et al. 2004) and grape vines (Vitis spp.) (Linaldeddu et al. 2014, Úrbez Torres et al. 2010). Botryosphaeriaceae 
members have been described as opportunistic pathogens (Kaya et al. 2014, Gezahgne et al. 2004) from diverse hosts and have commonly been found in areas of drought, summer flooding, and in areas of other present insect and fungal complexes (Alves et al. 2004).

As a grape vine pathogen, $D c$ has been reported in Mediterranean Europe, as well as in the U.S. states California and Texas, causing cankers and dieback of grape species (Linaldeddu et al. 2014, Úrbez Torres et al. 2010). As an oak pathogen, $D c$ has been implicated in oak decline in Mediterranean Europe and the U.S. although in association with several other abiotic and biotic complexes (Martin et al. 2017, Munck et al. 2017, Aćimović et al. 2016, Linaldeddu et al. 2014, Dreaden et al. 2011, Alves et al. 2004).

\section{Disease epidemiology}

Currently, the mode of ingress of $D c$ is unknown, however other Botryosphaeria spp. have been observed colonizing vascular cambial tissue through lenticels and/or present wounds (Guan et al. 2015, Pusey 1989). Other studies support the role of ambrosia beetles in serving as vectors of $D c$ in water stressed trees (Bellahirech et al. 2014). Once established, Diplodia will form a mycelial fan in the vascular cambium, causing a necrotic canker lesion as it expands outward (Munck et al. 2017, Aćimović et al. 2016, Martin et al. 2017 Linaldeddu et al. 2014, Dreaden et al. 2011, Alves et al. 2004). In oak hosts this colonization leads to symptoms including acute wilt, blighted leaves, dieback, sooty lesions and external cankers (Martin et al. 2017, Munck et al. 2017, Aćimović et al. 2016, Dreaden et al. 2011, Alves et al. 2004).

As fungal colonization progresses, conidia are produced from pycnidia that extrude from the bark, although spore production has not been regularly observed in the field (Lynch et al. 2013). These asexual spores are oblong to cylindrical in shape and hyaline in color. When 
immature these spores are aseptate but over time will darken to brown and develop septations (Alves et al. 2004). When both mating types are present, ascospores are produced in pseudothecia. These spores are fusiform in shape and light brown in color (Alves et al. 2004). Spores of Botryosphaeria spp. are predominantly dispersed by wind and rain, however, can potentially be carried by small animals and insects, as seen on grape hosts (Amponsah et al. 2009). When grown in culture on glucose yeast extract agar with antibiotics, $D c$ is a greenish white mycelial colony with irregular margins, which overtime, darkens into a grey colony with aerial mycelium (Martin and Munck 2017, Alves et al. 2004). These developed colonies of mycelium produce secondary metabolites, some of which have varying antifungal, phytotoxic and antibacterial activities which may increase virulence and resistance of $D c$ (Masi et al. 2016).

\section{Control}

Management of $D c$ can vary by severity and location; however, due to the opportunistic nature of $D c$, maintaining tree health and vigor in both forested and urban forests may be the best way to reduce incidence of infection. In urban settings, cleaning pruning equipment and avoiding pruning during heavy rain can aid in stopping spore dispersal (Martin and Munck 2017). Regardless of location, reducing the transport and properly disposing of infected plant material can help reduce the spread to new locations (Martin and Munck 2017).

In Europe, the use of fungicides including benomyl, carbendazim, thiophanate-methyl and cyprodinil + fludioxonil (SwitchÒ) on cork oak plantations after bark harvesting was shown to reduce the severity and/or presence of $D c$ associated cankers in field settings (Serrano et al. 2015, Luque et al. 2008). In the U.S., systemic fungicides were also recently evaluated for control of $D c$ and results indicated that three different fungicides, Propizol, Arbotect and 
Phosphojet, provided protection against canker development although some phytotoxicity was reported (Aćimović et al. 2019). Broad-scale use of fungicides outside of nurseries and plantations has been restricted due to potential secondary negative impacts on the health of ecosystems (Campanile et al. 2007). In attempts to control $D c$ without chemicals, the possibility of using saprotrophic fungi as an endophytic biocontrol against pathogenic fungi has been studied (Talapatra et al. 2017, Serrano et al. 2015, Campanile et al. 2006), however, it has not yet been confirmed as a reliable management strategy. Campanile and colleagues (2006) observed antagonistic activity of several fungi against $D c$ in European oak hosts, and found although possible in practice, this form of biocontrol does not yield consistent results. Future studies need to be conducted to assess secondary metabolite production and interaction between endophytic fungi and $D c$ isolates for both European and U.S. oak hosts.

\section{Summary}

Despite the cosmopolitan nature of $D c$, across Europe and the U.S., few studies have attempted to determine nativity of this fungal pathogen. Lynch and colleagues (2013) conducted a morphological and phylogenetic comparisons between $D c$ isolates collected in California, Italy, Spain and Portugal. This study confirmed pathogenicity of $D c$ in CA and provided a hypothesis

that $D c$ has undergone multiple introductions into the U.S. Although it provides a strong impetus for comparative phylogenetics between CA and Europe, their study included more isolates from Spain than from any other country, and the U.S. isolates recovered from oak hosts were only from CA. To better understand if all isolates of $D c$ were introduced, or if the U.S. has its own native strains, a broader survey and subsequent phylogenetic analyses need to be conducted to define the true geographic extent of this pathogen in the U.S. and how it compares to several other geographic locations in Europe. 


\section{References:}

Abrams, M.D., 1996. Distribution, historical development and ecophysiological attributes of oak species in the eastern United States. In Annales des Sciences Forestieres (Vol. 53, No. 2-3, pp. 487-512). EDP Sciences.

Aćimović, S.G., Harmon, C.L., Bec, S., Wyka, S., Broders, K. and Doccola, J.J., 2016. First report of Diplodia corticola causing decline of red oak (Quercus rubra) trees in Maine. Plant Disease, 100(3), p.649.

Aćimović, S.G., Martin, D.K., Turcotte, R.M., Meredith, C.L. and Munck, I.A., 2019. Choosing an Adequate Pesticide Delivery System for Managing Pathogens with Difficult Biologies: Case Studies on Diplodia corticola, Venturia inaequalis and Erwinia amylovora. In Plant Pathology and Management of Plant Diseases. IntechOpen.

Alves, A., Correia, A., Luque, J. and Phillips, A., 2004. Botryosphaeria corticola, sp. nov. on Quercus species, with notes and description of Botryosphaeria stevensii and its anamorph, Diplodia mutila. Mycologia, 96(3), pp.598-613.

Amponsah, N.T., Jones, E.E., Ridgway, H.J. and Jaspers, M.V., 2009. Rainwater dispersal of Botryosphaeria conidia from infected grapevines. New Zealand Plant Protection, 62, pp.228-233.

Amos, R.E. and True, R.P., 1967. Longevity of Ceratocystis fagacearum in roots of deep-girdled oak-wilt trees in West Virginia. Phytopathology, 57(10), pp.1012-+.

Asaro, C. and Chamberlin, L.A., 2015. Outbreak history (1953-2014) of spring defoliators impacting oak-dominated forests in Virginia, with emphasis on gypsy moth (Lymantria dispar L.) and fall cankerworm (Alsophila pometaria Harris). American Entomologist, 61(3), pp.174185.

Bellahirech, A., Inácio, M.L., Bonifácio, L., Nóbrega, F., Sousa, E. and Ben Jamâa, M.L., 2014. Comparison of fungi associated with Platypus cylindrus F.(Coleoptera: Platypodidae) in Tunisian and Portuguese cork oak stands. IOBC/wprs Bulletin, 101, pp.149-156.

Brasier, C.M. and Scott, J.K., 1994. European oak declines and global warming: a theoretical assessment with special reference to the activity of Phytophthora cinnamomi. EPPO Bulletin, 24(1), pp.221-232.

Brose, P.H., Gottschalk, K.W., Horsley, S.B., Knopp, P.D., Kochenderfer, J.N., McGuinness, B.J., Miller, G.W., Ristau, T.E., Stoleson, S.H. and Stout, S.L., 2008. Prescribing regeneration treatments for mixed-oak forests in the Mid-Atlantic region. Gen. Tech. Rep. NRS-33. Newtown Square, PA: US Department of Agriculture, Forest Service, Northern Research Station. 100 p., 33 .

da Clara, M.I.E. and de Almeida Ribeiro, N.M.C., 2013. Decline of Mediterranean oak trees and its association with Phytophthora cinnamomi: a review. European Journal of Forest Research, 132(3), pp.411-432. 
Campanile, G., Ruscelli, A. and Luisi, N., 2007. Antagonistic activity of endophytic fungi towards Diplodia corticola assessed by in vitro and in planta tests. European Journal of Plant Pathology, 117(3), pp.237-246.Cavender-Bares, J., 2016. Diversity, distribution, and ecosystem services of the North American oaks. International Oaks, 27, pp.37-48.

Cannon, C.H., 2001. Morphological and molecular diversity in Lithocarpus (Fagaceae) of Mount Kinabalu. Sabah Parks Nature Journal, 4, pp.45-69.

Cavender-Bares, J., 2016. Diversity, distribution, and ecosystem services of the North American oaks. International Oaks, 27, pp.37-48.

Coltswold. "ABOUT OAK." Oak Wood - Information about Oak Furniture, Wood and Trees The Cotswold Company, 2019, www.cotswoldco.com/info/oak/.

Corkforest-Blogger. "Harvesting the Cork Oak." Cork Forest Conservation Alliance, 3 May 2015, www.corkforest.org/harvesting-the-cork-oak/.

Denk, T., Grimm, G.W., Manos, P.S., Deng, M. and Hipp, A.L., 2017. An updated infrageneric classification of the oaks: review of previous taxonomic schemes and synthesis of evolutionary patterns. In Oaks Physiological Ecology. Exploring the Functional Diversity of Genus Quercus L. (pp. 13-38). Springer, Cham.

Dreaden, T.J., Shin, K. and Smith, J.A., 2011. First report of Diplodia corticola causing branch cankers on live oak (Quercus virginiana) in Florida. Plant disease, 95(8), pp.1027-1027.

Gerlach, J.P., Reich, P.B., Puettmann, K. and Baker, T., 1997. Species, diversity, and density affect tree seedling mortality from Armillaria root rot. Canadian Journal of Forest Research, 27(9), pp.1509-1512.

Gezahgne, A., Roux, J., Slippers, B., Wingfield, M.J. and Hare, P.D., 2004. Identification of the causal agent of Botryosphaeria stem canker in Ethiopian Eucalyptus plantations. South African journal of botany, 70(2), pp.241-248.

Guan, Y., Chang, R., Liu, G., Wang, Y., Wu, T., Han, Z. and Zhang, X., 2015. Role of lenticels and microcracks on susceptibility of apple fruit to Botryosphaeria dothidea. European journal of plant pathology, 143(2), pp.317-330.

Hansen, E., 2003. Phytophthora in North American forests. In Sudden Oak Death Online Symposium. American Phytopathological Society (Vol. 4).

Kaya, A.G.A., Lehtijärvi, A., Kaya, Ö. and Doğmuş-Lehtijärvi, T., 2014. First report of Diplodia pinea on Pseudotsuga menziesii in Turkey. Plant disease, 98(5), pp.689-689.

Keča, N., Koufakis, I., Dietershagen, J., Nowakowska, J.A. and Oszako, T., 2016. European oak decline phenomenon in relation to climatic changes. Folia Forestalia Polonica, 58(3), pp.170177. 
Linaldeddu, B.T., Maddau, L. and Franceschini, A., 2017. First Report of Diplodia corticola Causing Canker and Dieback of Quercus ilex, Q. petraea, and Q. suber in Corsica (France). Plant Disease, 101(1), pp.256-256.

Linaldeddu, B.T., Scanu, B., Maddau, L. and Franceschini, A., 2014. Diplodia corticola and Phytophthora cinnamomi: the main pathogens involved in holm oak decline on Caprera Island (Italy). Forest Pathology, 44(3), pp.191-200.

Lynch, S.C., Eskalen, A., Zambino, P.J., Mayorquin, J.S. and Wang, D.H., 2013. Identification and pathogenicity of Botryosphaeriaceae species associated with coast live oak (Quercus agrifolia) decline in southern California. Mycologia, 105(1), pp.125-140.

Lynch, S.C., Eskalen, A., Zambino, P. and Scott, T., 2010. First report of bot canker caused by Diplodia corticola on coast live oak (Quercus agrifolia) in California. Plant disease, 94(12), pp.1510-1510.

Juzwik, J., Appel, D.N., MacDonald, W.L. and Burks, S., 2011. Challenges and successes in managing oak wilt in the United States. Plant Disease, 95(8), pp.888-900.

Jacobi, W.R. and MacDonald, W.L., 1980. Colonization of resistant and susceptible oaks by Ceratocystis fagacearum. Phytopathology, 70(7), pp.618-623.

Luque, J., Pera, J. and Parladé, J., 2008. Evaluation of fungicides for the control of Botryosphaeria corticola on cork oak in Catalonia (NE Spain). Forest Pathology, 38(3), pp.147155.

MacDonald, W.L., Pinon, J., Tainter, F.H. and Double, M.L., 2001. European oaks-susceptible to oak wilt. Shade Tree Wilt Diseases. APS Press, St. Paul, MN, pp.131-137.

Martin, D.K.H., Turcotte, R.M., Miller, T.M., Munck, I.A., Aćimović, S.G., Macias, A.M., Stauder, C.M. and Kasson, M.T., 2017. First report of Diplodia corticola causing stem cankers and associated vascular occlusion of northern red oak (Quercus rubra) in West Virginia. Plant Disease, 101(2), pp.380-380.

Martin Danielle, K., and Isabel Munck. "Pest Alert Diplodia Corticola "Bot Canker" of Oak" NA-PR-01-17 , U.S. Department of Agriculture, Forest Service, Northeastern Area State and Private Forestry, April 2017

Masi, M., Maddau, L., Linaldeddu, B.T., Cimmino, A., D’Amico, W., Scanu, B., Evidente, M., Tuzi, A. and Evidente, A., 2015. Bioactive secondary metabolites produced by the oak pathogen Diplodia corticola. Journal of agricultural and food chemistry, 64(1), pp.217-225.

Meier, Eric. "Holm Oak." The Wood Database, 2008, www.wood-database.com/holm-oak/. 
McConnell, M.E. and Balci, Y., 2014. Phytophthora cinnamomi as a contributor to white oak decline in Mid-Atlantic United States forests. Plant disease, 98(3), pp.319-327.

De Micco, V., Balzano, A., Wheeler, E.A. and Baas, P., 2016. Tyloses and gums: a review of structure, function and occurrence of vessel occlusions. IAWA journal, 37(2), pp.186-205.

Munck, Isabel. 2017 “ Pest Alert Oak Wilt in the Northeastern United States”, NA-PR-02-17, U.S. Department of Agriculture, Forest Service, Northeastern Area State and Private Forestry, July 2017.

Moricca, S., Linaldeddu, B.T., Ginetti, B., Scanu, B., Franceschini, A. and Ragazzi, A., 2016. Endemic and emerging pathogens threatening cork oak trees: Management options for conserving a unique forest ecosystem. Plant disease, 100(11), pp.2184-2193.

Nixon, K.C., 2006. Global and neotropical distribution and diversity of oak (genus Quercus) and oak forests. In Ecology and conservation of neotropical montane oak forests (pp. 3-13). Springer, Berlin, Heidelberg.

Oak, S.W., Spetich, M.A. and Morin, R.S., 2016. Oak decline in central hardwood forests: frequency, spatial extent, and scale. In Natural Disturbances and Historic Range of Variation (pp. 49-71). Springer, Cham.

Pusey, P.L., 1989. Availability and dispersal of ascospores and conidia of Botryosphaeria in peach orchards. Phytopathology, 79(6), pp.635-639.

Raabe, R. "Host list of the root rot fungus, Armillaria mellea." Hilgardia 33.2 (1962): 25-88.

Reed, S.E., English, J.T., Lalk, S.R. and Tosie, K.M., 2018. First report of Diplodia corticola causing stem and branch cankers on white oak (Quercus alba) in Missouri, USA. Plant disease, 102(12), p.2657.

Rogers, R., 1990. Quercus alba L. White oak. Silvics of North America, 2, pp.605-613.

Sander, I.L., 1990. Quercus rubra L. Northern red oak. Silvics of North America, 2, pp.727-733.

Serrano, M.S., Romero, M.A., Jiménez, J.J., De Vita, P., Avila, A., Trapero, A. and Sánchez, M.E., 2015. Preventive control of Botryosphaeria canker affecting Quercus suber in southern Spain. Forestry: An International Journal of Forest Research, 88(4), pp.500-507.

Shigo, A.L., 1958. Fungi isolated from oak-wilt trees and their effects on Ceratocystis fagacearum. Mycologia, 50(5), pp.757-769.

Smith, D.R. and Stanosz, G.R., 2018. Occurrence of Diplodia corticola, including new oak host records, in Wisconsin, USA. Forest pathology, 48(4), p.e12427. 
Stolte, K.W., Conkling, B.L., Fulton, S. and Bradley, M.P., 2012. State of Mid-Atlantic region forests in 2000. Gen. Tech. Rep. SRS-162. Asheville, NC: US Department of Agriculture Forest Service, Southern Research Station. 203 p., 162, pp.1-203.

Sturrock, R.N., Frankel, S.J., Brown, A.V., Hennon, P.E., Kliejunas, J.T., Lewis, K.J., Worrall, J.J. and Woods, A.J., 2011. Climate change and forest diseases. Plant pathology, 60(1), pp.133149.

Talapatra, K., Das, A.R., Saha, A.K. and Das, P., 2017. In vitro antagonistic activity of a root endophytic fungus towards plant pathogenic fungi. Journal of Applied Biology \& Biotechnology Vol, 5(02), pp.068-071.

Tiberi, R., Branco, M., Bracalini, M., Croci, F. and Panzavolta, T., 2016. Cork oak pests: a review of insect damage and management. Annals of forest science, 73(2), pp.219-232.

Úrbez-Torres, J.R., Peduto, F., Rooney-Latham, S. and Gubler, W.D., 2010. First report of Diplodia corticola causing grapevine (Vitis vinifera) cankers and trunk cankers and dieback of canyon live oak (Quercus chrysolepis) in California. Plant disease, 


\title{
Chapter Two: Global Comparisons Among Diplodia corticola Affecting Oak Species
}

\author{
Abstract: \\ In Mediterranean Europe, oak species (Quercus spp.) have been in a state of declining \\ health and vigor for the past several decades. Several biotic factors have been found to contribute \\ to this decline to varying degrees including Phytophthora cinnamomi, Armillaria spp., and \\ various insect defoliators. More recently, Diplodia corticola, an emerging canker pathogen, has \\ been implicated in causing dieback and mortality of oak species in Europe and in several \\ geographically disjunct regions in the United States. In an attempt to determine the origin(s) of \\ Diplodia corticola and whether it should be considered an introduced pathogen in the U.S., a \\ phylogenetic study and an associated morphological study were conducted to resolve \\ relationships among Diplodia isolates from geographically discrete populations in both Europe \\ and the U.S. A total of 23 Diplodia isolates from Spain, France, Italy and the U.S. were studied, \\ including 20 previously ITS-barcoded $D$. corticola $(D c)$ isolates, two $D$. quercivora $(D q)$ \\ isolates, and one D. mutila $(\mathrm{Dm})$ isolate. Many of these isolates had been previously included in \\ pathogenicity tests. Across all isolates and geographic regions, $D c$ formed a strongly supported \\ clade sister to $D q$ and included at least three moderately supported subclades. One subclade \\ included isolates from Spain and California, a second included isolates from Italy and West \\ Virginia, and a third included isolates from Maine and Massachusetts. The Spain and California \\ isolates also exhibited overlapping culture morphology and spore measurements, but larger \\ trends based on these morphological features across $D c$ were not consistent or phylogenetically \\ informative. The results of this study offer support for $D c$ as a cosmopolitan pathogen, present in
}


both Europe and the U.S. but with the possibility of global movement based on phylogenetic and morphological resolution.

\section{Introduction:}

Oak trees (Quercus spp.) in Mediterranean Region of Europe have been in a state of declining health and vigor for the last several decades, with a notable increase in mortality beginning in the 1980s (da Clara and de Ribeiro 2013, Linaldeddu et al. 2014, Alves et al. 2004). This broad-scale decline has been contributed to several abiotic complexes including drought and flooding (Linaldeddu et al. 2014, Alves et al. 2004, Brasier and Scott 1994) as well as biotic complexes such as Phytophthora cinnamomi (Keča et al. 2016, Linaldeddu et al. 2014, da Clara et al. 2013), Armillaria spp., and various insect defoliators (Keča et al. 2016).

Initial reports of European oak decline were incorrectly attributed to several species of Diplodia including D. mutila, D. quercina, D. quercuum and D. stevensii, which have since been confirmed as Diplodia corticola $(D c)$, the anamorph state of Botryosphaeria corticola (Alves et al. 2004). Diplodia corticola has been documented causing disease on cork oak (Q. suber), evergreen oak (Q. ilex), sessile oak (Q. petraea) and turkey oak (Q. cerris) in Portugal, Spain, Italy and France (Linaldeddu et al. 2017, Lazzizera et al. 2008, Alves et. al 2004). Oak trees in this region are commercially harvested for making wine and bourbon barrels and wine corks, (Coltswold 2019, Meier 2008), with cork oak trees having an increased risk of Dc infection due to the mechanical damage inflicted during the process of harvesting cork oak bark (Cork Forest Conservation Alliance 2015).

In the early 2000s, California's costal live oaks were in a noticeable decline throughout San Diego County, some of which was attributed to the insect pest, the goldspotted oak borer 
(Agrilus auroguttatus) (Lynch et al. 2010). In 2008, members of Botryosphaeriaceae were also implicated in this decline of coastal live oaks, which were later confirmed as $D c$ (Lynch et al. 2010). Since then, $D c$ has been identified as causing disease on red oak ( $Q$. rubra), black oak ( $Q$. velutina), bur oak ( $Q$. macrocarpa), southern live oak ( $Q$. virginiana), coast live oak ( $Q$. agrifolia $)$ and white oak $(Q . a l b a)$ in Washington D.C. and eight U.S. states including California (Lynch et al. 2010), Florida (Dreaden et a. 2011), Maine (Aćimović et al. 2016), Massachusetts (Munck et al. 2017), Missouri (Reed et al. 2018), Pennsylvania (Martin and Munck 2017), West Virginia (Martin et al. 2017) and Wisconsin (Smith and Santosz 2018), with first detections coming from California in the early 2000s (Lynch et al. 2010).

In both Europe and the U.S., affected trees have been reported showing one or a combination of outward symptoms including acute wilt, blighted leaves, external cankers, necrotic lesions, severe dieback, and death (Aćimović et al. 2016, Alves et al. 2004, Dreaden et al. 2011, Munck et al. 2017, Martin et al. 2017).

Despite the broad geographic distribution of $D c$ isolates across the U.S. and the relatively short time frame in which they were discovered, few studies have attempted to make meaningful comparisons among these $D c$ isolates or between $D c$ and $D$. quercivera $(D q)$, another important, although less common oak pathogen in the U.S. (Braganca et al. 2016, Dreaden et al. 2014). However, one study compared pathogenicity among $D c$ isolates from ME, MA, and WV on inoculated red oak seedlings under greenhouse conditions, revealing similar levels of disease after eight weeks (Martin et al. 2017). More recently, Haines et al. (2019) compared a single $D c$ isolate recovered from WV (Martin et al. 2017) with a $D q$ isolate from MD, revealing the $D q$ isolate produced larger cankers on inoculated chestnut oak (Quercus montana). More inclusive molecular and morphological comparisons have not been pursued previously possibly due to 
many of the isolates having only ITS sequences determined, which is phylogenetically uninformative. Additionally, there were no meaningful morphological characters described beyond colony morphology across most of these studies.

Given these previous limitations, a multi-gene phylogenetic analysis and an associated morphological study were conducted to better resolve relationships among $D c$ isolates from geographically discrete populations in both Europe and the U.S. In doing so, we sought to look for evidence of nativity based on sequence similarity/divergence and possible fine-scale phylogenetic structure as well as diagnostically informative patterns among morphological measurements that might support the phylogenetic findings.

\section{Methods:}

\section{$\underline{\text { Isolate Selection }}$}

Diplodia spp. isolates were acquired from various university and government collections in Europe and the U.S. with isolates from Q. alba, Q. agrifolia, Q. cerris, $Q$ ilex, $Q$. montana $Q$. rubra, $Q$. suber, $Q$. velutina, and $Q$. virginiana from France, Italy, Spain and the U.S. Isolates used were based on availability, isolate origin, and viability of the isolate following removal from storage. This resulted in 23 total isolates: $20 \mathrm{Dc}$ isolates including 13 from the U.S., six isolates from Spain and one isolate from Italy as well as two isolates for both $D q$ (U.S.) and $D m$ (France), which served as reference in-groups for Diplodia. For a list of isolates and locations see Table 1. 
Table 1: Isolate name and location of selected Diplodia spp.

\begin{tabular}{|c|c|c|c|c|c|}
\hline Isolate & Additional ID & $\begin{array}{c}\text { Included In } \\
\text { Phylogenetic } \\
\text { Analysis? }\end{array}$ & Host & Location & $\begin{array}{l}\text { Diplodia } \\
\text { spp. }\end{array}$ \\
\hline UCR1246 & JN693501 & Yes & Q. agrifolia & $\mathrm{CA}, \mathrm{USA}$ & $D c$ \\
\hline UCR1339 & JQ411401 & Yes & Q. agrifolia & CA, USA & $\overline{D c}$ \\
\hline UCR488 & JN6693501 & Yes & Q. agrifolia & CA, USA & $D c$ \\
\hline PL1447 & MTF11 AB & Yes & Q. virginiana & FL, USA & $D c$ \\
\hline PL1480 & SVH1 AB & No & Q. virginiana & FL, USA & $\overline{D c}$ \\
\hline PL1518 & OSC3 B1 AB & Yes & Q. virginiana & $\mathrm{FL}, \mathrm{USA}$ & $\overline{D c}$ \\
\hline CJL374 & - & Yes & Q. suber & France & $D m$ \\
\hline CJL364 & - & Yes & Q. cerris & Italy & $D c$ \\
\hline DC113 & HR 25-1-1 & Yes & Q. rubra & MA, USA & $D c$ \\
\hline DC114 & WHG PRKL-1-5 & Yes & Q. rubra & MA, USA & $D q$ \\
\hline DQ703 & MK160499 & Yes & Q. montana & $\mathrm{MD}, \mathrm{USA}$ & $D q$ \\
\hline DC117 & OTL181 & Yes & Q. rubra & $\mathrm{ME}, \mathrm{USA}$ & $D c$ \\
\hline DC118 & OTCT3-1 & Yes & Q. rubra & ME, USA & $D c$ \\
\hline CJL155 & CBS112071 & No & Q. ilex & Spain & $D c$ \\
\hline CJL245 & CBS112072 & No & Q. ilex & Spain & $D c$ \\
\hline CJL248 & CBS112073 & Yes & Q. suber & Spain & $D c$ \\
\hline CJL255 & - & Yes & Q. ilex & Spain & $D c$ \\
\hline CJL338 & CBS112547 & Yes & Q. ilex & Spain & $D c$ \\
\hline $\begin{array}{l}\text { CJL47 } \\
\end{array}$ & CBS678.88 & No & Q. suber & Spain & $D c$ \\
\hline WI 03-35 & - & Yes & Q. alba & WI, USA & $D c$ \\
\hline DC103 & QURU O 10 & Yes & Q. rubra & WV, USA & $D c$ \\
\hline DC105 & QURU2 R & Yes & Q. rubra & WV, USA & $D c$ \\
\hline DC110 & B012 & No & Q. rubra & WV, USA & $D c$ \\
\hline
\end{tabular}

Isolate and Phylogenetic Analysis

Prior to this study, DNA sequences from several of the Diplodia isolates used in this study were deposited into GenBank for several gene regions (Appendix: Table 1). For isolates missing sequence data for one or more gene regions, sub-cultures of these same strains were transferred from stock cultures to glucose yeast extract agar with antibiotics (GYEA) that had a surface layer of sterile cellophane and grown for approximately one week, after which, mycelium was scraped from the cellophane into a $1.5 \mathrm{~mL}$ microcentrifuge tubes (Eppendorf, Hamburg, Germany) for DNA extraction. Sealed tubes were flash frozen for five seconds in liquid nitrogen, after which frozen samples were macerated. Following maceration, $600 \mu 1$ of 
Nuclei Lysis Solution (Promega, Madison, WI, USA) was added to each tube and incubated at $65{ }^{\circ} \mathrm{C}$ in a water bath for one-hour, vortexing for 10 seconds after 30 minutes. After one hour, samples were removed from the water bath and allowed to cool at room temperature for five minutes. Once cooled, $200 \mu 1$ of Protein Precipitation Solution was added (Promega, Madison, WI, USA), and tubes were again vortexed for 10 seconds. Samples were then centrifuged for three minutes at 14,000 RPM, and the supernatant was removed and transferred into a new sterile $1.5 \mathrm{~mL}$ centrifuge tube containing $600 \mu \mathrm{l}$ of isopropanol. The original tube and pellet were discarded. These newly transferred tubes were gently mixed by pipetting and then were centrifuged for three minutes at 14,000 RPM. The resulting centrifuge tube contained a supernatant, which was discarded, and a pellet that was retained. Tubes containing pellets received $600 \mu \mathrm{l}$ of $70 \%$ ethanol and were gently inverted before being centrifuged for two minutes at 14,000 RPM. The resulting supernatant was again discarded, and the pellet was retained. Tubes containing pellets were open and inverted for 15 minutes to dry at room temperature. The remaining pellet was then resuspended in $100 \mu \mathrm{l}$ of $65^{\circ} \mathrm{C}$ Elution Buffer (Alfa Aesar, Ward Hill, MA, USA) and stored in a $-20{ }^{\circ} \mathrm{C}$ freezer until needed.

All collected Diplodia isolates were PCR amplified for the internal transcribed spacer region (ITS) using primers ITS4 and ITS5, the elongation factor gene (EF-1 $\alpha$ ) using primers ef11782 and ef1-1567 and the large subunit (LSU) using primers LR5-LROR. To amplify these products, $10 \mu \mathrm{l}$ of molecular-grade water (G-Biosciences, St. Louis, MO, USA), $12.5 \mu 1$ of Master Mix (Bioline, London, UK), $1 \mu \mathrm{l}$ of each respective forward and reverse primer (IDT, Coralville, IA, USA), and $1.5 \mu 1$ of template DNA were combined.

ITS and EF-1 $\alpha$ gene regions were amplified using a three stage PCR reaction: an initial melting stage at $95^{\circ} \mathrm{C}$ for two minutes, followed by 35 cycles of $95^{\circ} \mathrm{C}$ for 30 seconds, $56{ }^{\circ} \mathrm{C}$ for 
30 seconds, $72{ }^{\circ} \mathrm{C}$ for 60 seconds, and lastly a final extension at $72{ }^{\circ} \mathrm{C}$ for seven minutes. LSU gene region amplification was as follows: an initial melting at $95^{\circ} \mathrm{C}$ for two minutes; 35 cycles of $95{ }^{\circ} \mathrm{C}$ for 30 seconds, $51.1^{\circ} \mathrm{C}$ for 45 seconds, and $72{ }^{\circ} \mathrm{C}$ for 90 seconds; and lastly, a final extension at $72{ }^{\circ} \mathrm{C}$ for five minutes.

After PCR, $10 \mu \mathrm{l}$ of PCR product were added to $4 \mu \mathrm{l}$ of SYBER Gold (Invitrogen, Grand Island, NY, USA) and $4 \mu \mathrm{l}$ of gel loading dye blue 6X (New England BioLabs Inc., MA, USA) before being pipetted into a $1.5 \%$ w/v agarose (Amresco, Solon, OH, USA) gel with 0.5\% TrisBorate-EDTA buffer (Amresco, Solon, OH, USA). Using electrophoresis, resulting bands were analyzed on a UV transilluminator (Bio-Rad, Hercules, CA, USA) to visually confirm DNA amplification. After analysis, PCR products that were deemed to be of good quality, were purified using ExoSAP-IT (Affymetrix, Santa Clara, CA, USA) in a reaction which consisted of a mixture of $6 \mu \mathrm{l}$ of PCR product, $2.2 \mu \mathrm{l}$ of ExoSAP and $2 \mu 1$ of molecular-grade water (GBiosciences, St. Louis, MO). After purification, products were Sanger-sequenced (Eurofins, Louisville, KY, USA) using the same primers that were utilized for the respective PCR.

Chromatograms were clipped in CodonCode Aligner v. 5.1.5 followed by manual screening of sequences (as sequence alignments) for missing or miscalled nucleotides. Each of the three analyzed gene regions were separately aligned using MEGA v. 7.0.16 (Kumar et al. 2016) and then combined into a single aligned gene using FaBox (Villesen 2007). For maximum likelihood analyses, a best fitting model was chosen using Model Selection analysis and 1,000 bootstrap replicates were used with the best tree being identified and bootstrapped in a single run. In the final selected tree, strong boot-strap support was observed and documented if bootstrap values met or exceeded $70 \%$ and marginal support if boot-strap values were between $50 \%$ 
and $69 \%$. Boot-strap values that were less than $50 \%$ are considered weak support and were not included in the analysis.

$\underline{\text { Spore Production and Associated Measurements }}$

Austrian pine (Pinus nigra) needles were previously reported to induce pycnidia production in some Botryosphaeria species when used in media ( $\mathrm{Su}$ et al. 2012). To test this effect on $D c$ and the other Diplodia spp. from oak, isolates were grown on PDA with additional autoclaved eastern white pine (Pinus strobus) needles added to the plate surface as the media cooled. $D c$ grew over the pine needles but did not sporulate during the four weeks plates were monitored. Concurrent to these studies, $D c$ isolates were also grown on pine needle extract agar (PNE) to induce sporulation, with slight modification to Su et al. (2012). Twenty grams of potato dextrose broth was substituted for 20 grams of potatoes. Isolates were transferred from pure cultures and grown on PNE for two weeks but did not result in pycnidia production. However, when grown on modified PNE, the previously identified Diplodia isolates lost their characteristic fluffy greyish white growth and irregular margins, and instead grouped into two distinct morphotypes. Plating of several additional isolates onto modified PNE confirmed these observations.

A single $D c$ isolate from $\mathrm{WV}$ that had dried out after a prolonged window of observation (>1 month), formed pycnidia on GYE. Based on this result, additional $D c$ cultures were grown on $1 / 10^{\text {th }}$ strength GYE to induce pycnidia production, with the rationale that drastically limiting the nutrient source could induce sporulation. Selected isolates were transferred as $0.5 \mathrm{~cm}$ fully colonized plug to $1 / 10^{\text {th }} \mathrm{GYE}$ and left under continuous light for four weeks. An identical set of cultures were plated and left in the dark for four weeks. After that time, the cultures that had grown in the dark did not produce any pycnidia or conidia, while most cultures that grew in the 
light did. After one-month, morphological observations including presence of pycnidia and spore measurements were made. Spores were mounted on slides containing lactophenol to observe spore size and morphology. The length and width of twenty-five randomly selected spores were measured at the longest point using a Nikon Eclipse E600 microscope and NIS-Elements BR 3.2 under 40X magnification. Spore sizes and associated features (i.e. number of septations and spore pigmentation) were compared between species and among geographic location using analysis of variance (ANOVA) and then between locations using Tukey Kramer's post HOC test.

A follow-up analysis of the modified PNE was also conducted with 17 isolates of Diplodia spp. Selected Diplodia isolates were plated from the $1 / 10^{\text {th }}$ strength GYE used for spore analysis to PNE using a fully colonized $0.5 \mathrm{~cm}$ diameter plug and allowed to grow for two weeks. After two weeks, morphology of isolates was observed between species and geographic location.

\section{Results:}

\section{$\underline{\text { Phylogenetics }}$}

Eighteen of the previously selected 23 Diplodia spp. including 15 of $20 D c$ isolates, two $D q$ isolates, and one $D m$ isolate were included in the single-gene and concatenated datasets and were subjected to phylogenetic analysis. Botryosphaeria fusispora served as an outgroup in both the single gene and concatenated datasets (Slippers et al. 2013). The three-gene concatenated dataset resolved all selected Diplodia species, except for Dm, into a strongly supported monophyletic group (91\% bootstrap support) with two major clades; one clade comprised of $D c$ with a $98 \%$ bootstrap support and a second clade containing $D q$ with an $84 \%$ bootstrap support (Figure 1). Interestingly, one of the previously identified $D q$ isolates from MA, aligned with the 
reference $D q$ from MD, although remained distinct. Among three single gene trees, EF-1 $\alpha$ (Figure 3) was the only tree that had an identical topology with the 3-gene concatenated tree and had strong support for both the clade containing $D c$ and $D q$ and each individual species. ITS (Figure 1) and LSU (Figure 4) had moderate support for the clade containing $D c$ and $D q$ as well as the clade containing $D c$.

The single EF-1 $\alpha$ gene tree (Figure 3) also exhibited strong bootstrap support (86\%) for a subclade within the $D c$ clade that included both Spain and CA isolates and moderate bootstrap support (58\%) for a subclade containing isolates from WV and Italy. ITS exhibited a different topology within $D c$ showing moderate (62\%) support for a clade containing two of three of the Spain isolates along with two isolates from ME and one isolate from FL (Figure 2). These subclades are still visible in the concatenated tree; however, bootstrap support is only $58 \%$ and $61 \%$, respectively (Figure 3). A third $D c$ subclade, present only in the concatenated tree, contained three isolates from MA and ME with moderate (58\%) bootstrap support (Figure 1). 


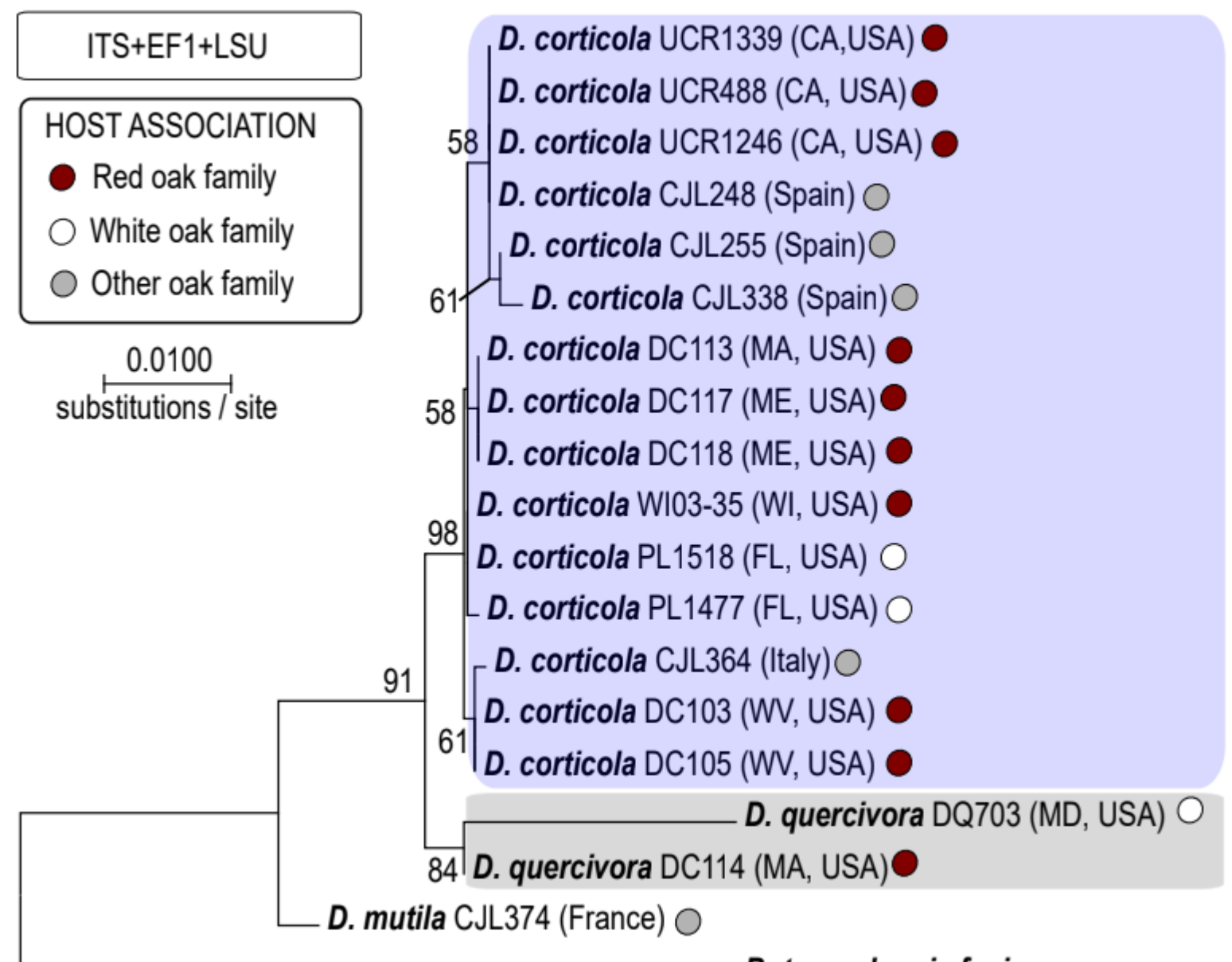

Botryosphaeria fusispora

Figure 1: Phylogenetic tree showing the three-gene concatenated gene regions comprising ITS, EF- $1 \alpha$ and LSU for 19 analyzed isolates. For maximum likelihood analyses, a best fitting model was chosen using Model Selection analysis and 1,000 bootstrap replicates were used with the best tree being identified and bootstrapped in a single run. 


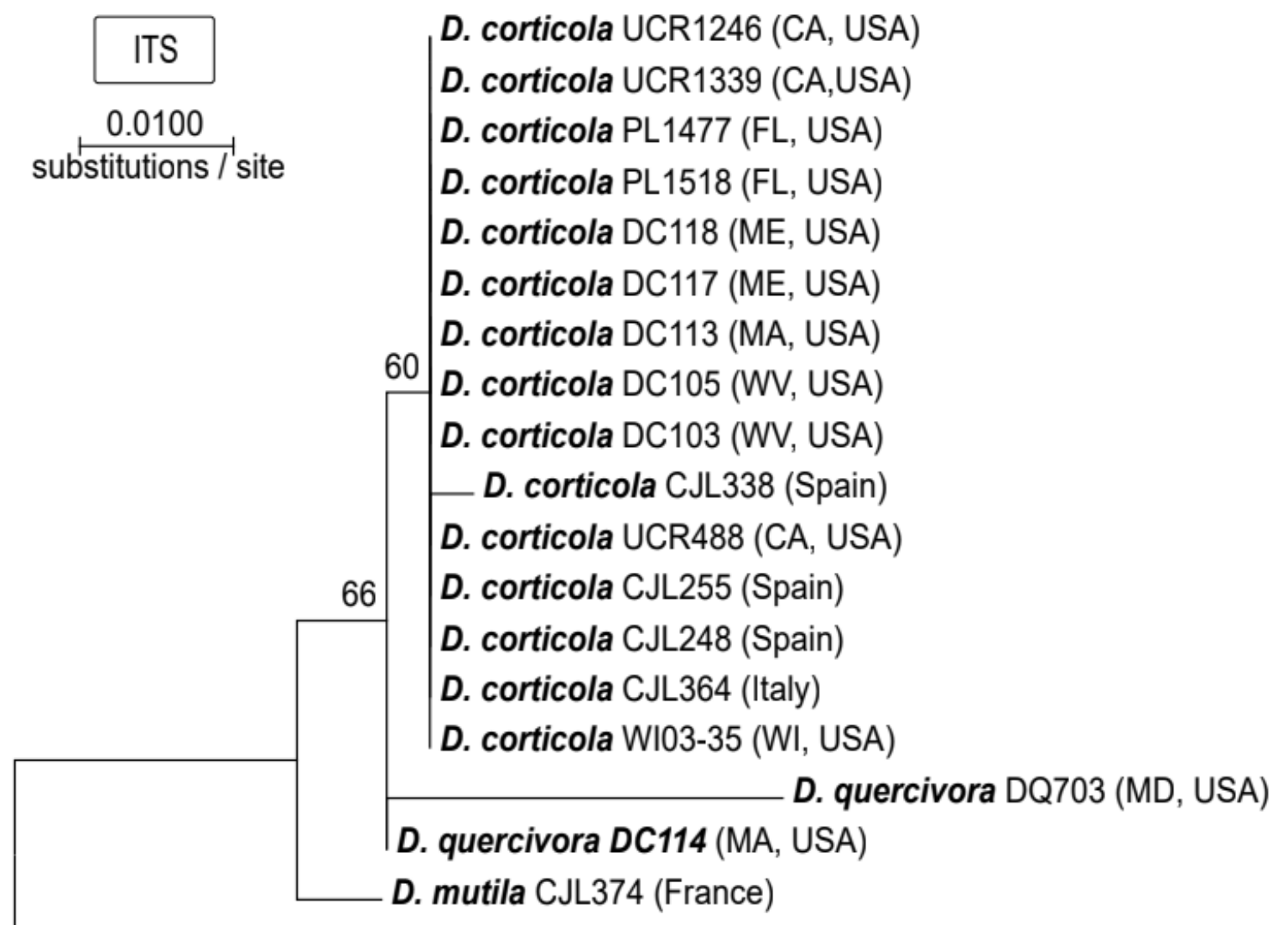

Botryosphaeria fusispora JX646789

Figure 2: Phylogenetic tree showing ITS gene region for 19 analyzed isolates. For maximum likelihood analyses, a best fitting model was chosen using Model Selection analysis and 1,000 bootstrap replicates were used with the best tree being identified and bootstrapped in a single run. 


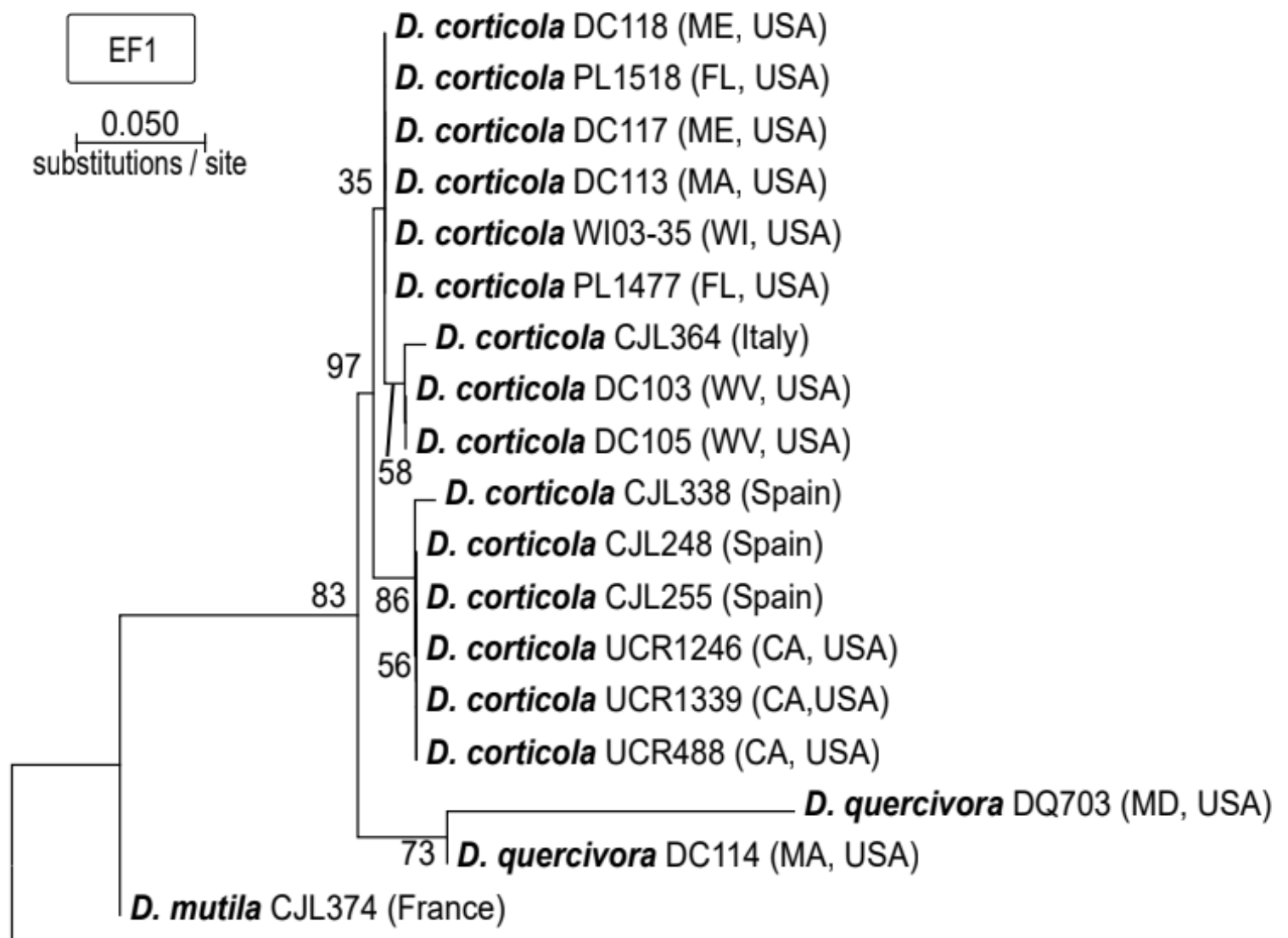

Botryosphaeria fusispora JX646854

Figure 3: Phylogenetic tree showing EF-1 $\alpha$ gene region for 19 analyzed isolates. For maximum likelihood analyses, a best fitting model was chosen using Model Selection analysis and 1,000 bootstrap replicates were used with the best tree being identified and bootstrapped in a single run. 


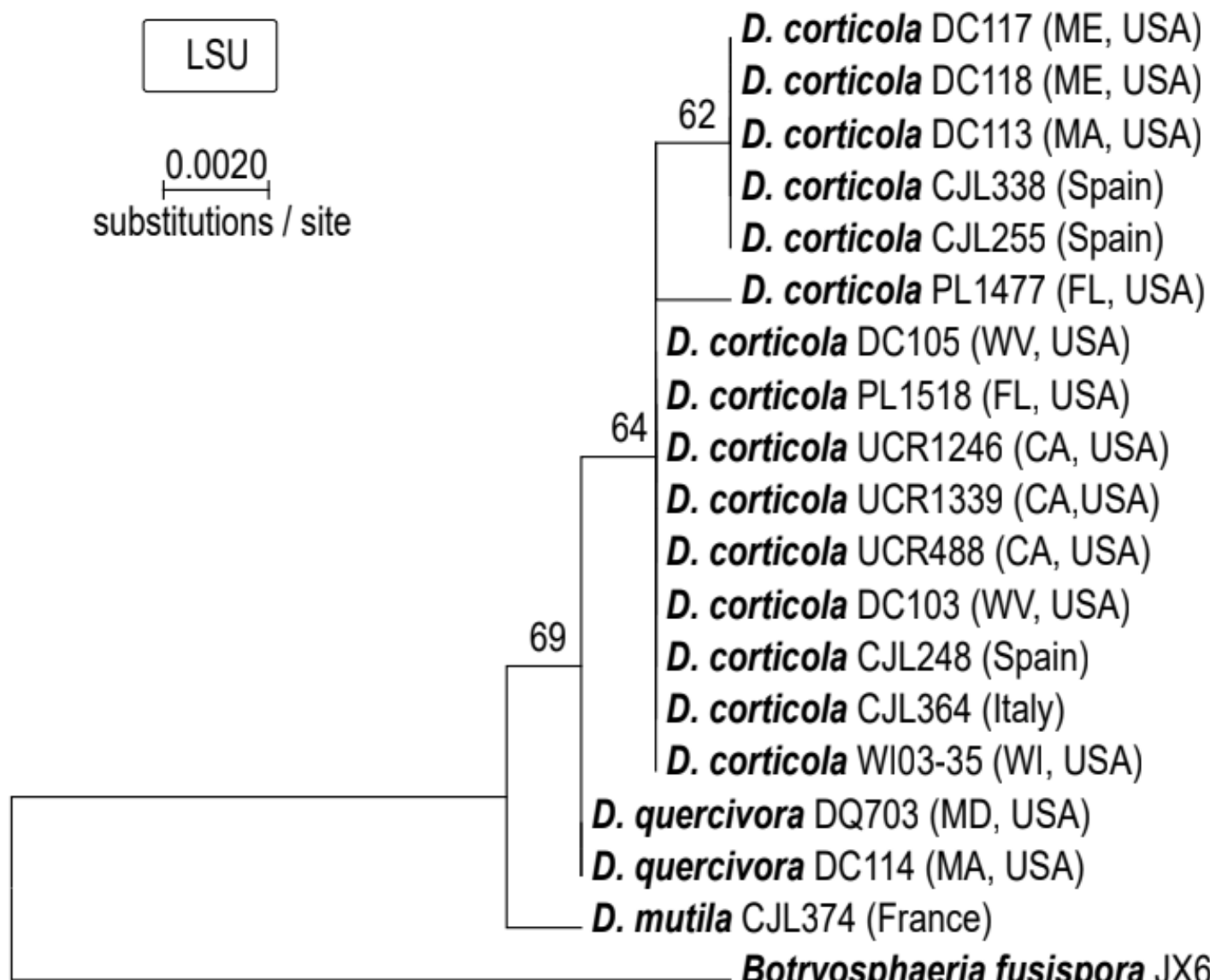

Botryosphaeria fusispora JX646806

Figure 4: Phylogenetic tree showing LSU gene region for 19 analyzed isolates. For maximum likelihood analyses, a best fitting model was chosen using Model Selection analysis and 1,000 bootstrap replicates were used with the best tree being identified and bootstrapped in a single run.

Spore Production and Associated Measurements

Twenty-three isolates were plated on $1 / 10^{\text {th }}$ strength GYE under continuous light to induce sporulation. After four weeks, conidia were observed from 22 Diplodia spp. isolates (Figure 5C-F). Pycnidia were typically visible within two weeks of plating, with spores typically becoming visible within the following week (Figure 5B). Average spore sizes were determined by averaging the measurements of each spore's widest and longest point. Twenty-five randomly selected spores' measurements were averaged for each isolate. 

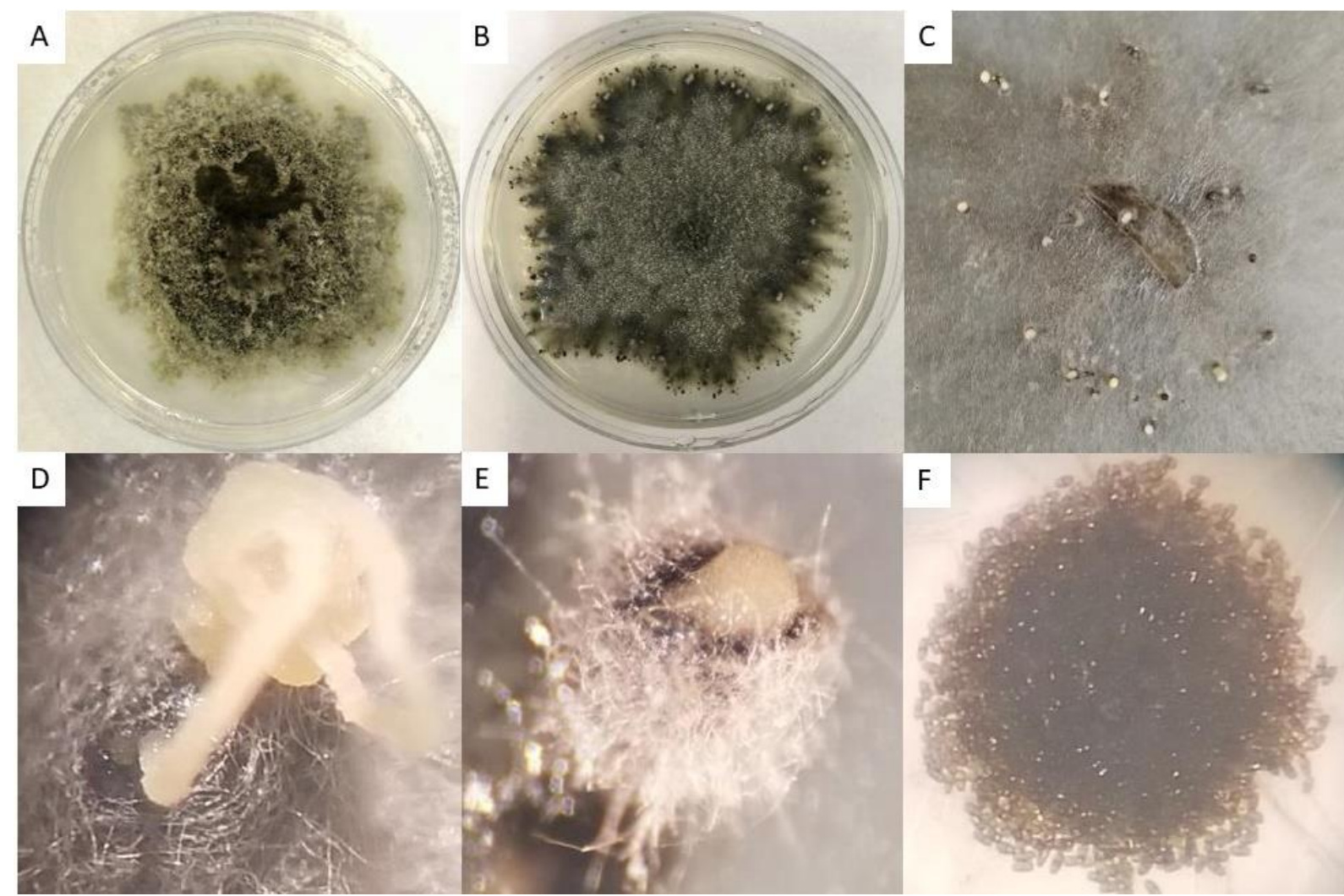

Figure 5: A) $D c$ isolate growing on GYEA, B) $D c$ isolate developing pycnidia precursors on $\left.1 / 10^{\text {th }} \mathrm{GYE}, \mathrm{C}\right) \mathrm{Dc}$ isolate exuding conidia from numerous pycnidia on $1 / 10^{\text {th }} \mathrm{GYE}, \mathrm{D}$ ) Conidial tendril being exuded from pycnidia, E) Mass of conidia being exuded from pycnidia, F) Mass of brown septate conidia.

Spores were recovered from $19 D c$ isolates, averaging $19.84 \mu \mathrm{m}$ with a standard deviation of $1.75 \mu \mathrm{m}$. One isolate CJL338 from Spain did not produce spores even after two months of observation. Among all isolates, $D c$ conidia were typically spherical to elliptical in shape and hyaline in color (Figure 6A-D). Frequently, slide mounts contained fewer brownpigmented uniseptate spores (Figure 6D). Isolates from CA and FL also had multi-septate brownpigmented spores (Figure 6A). 

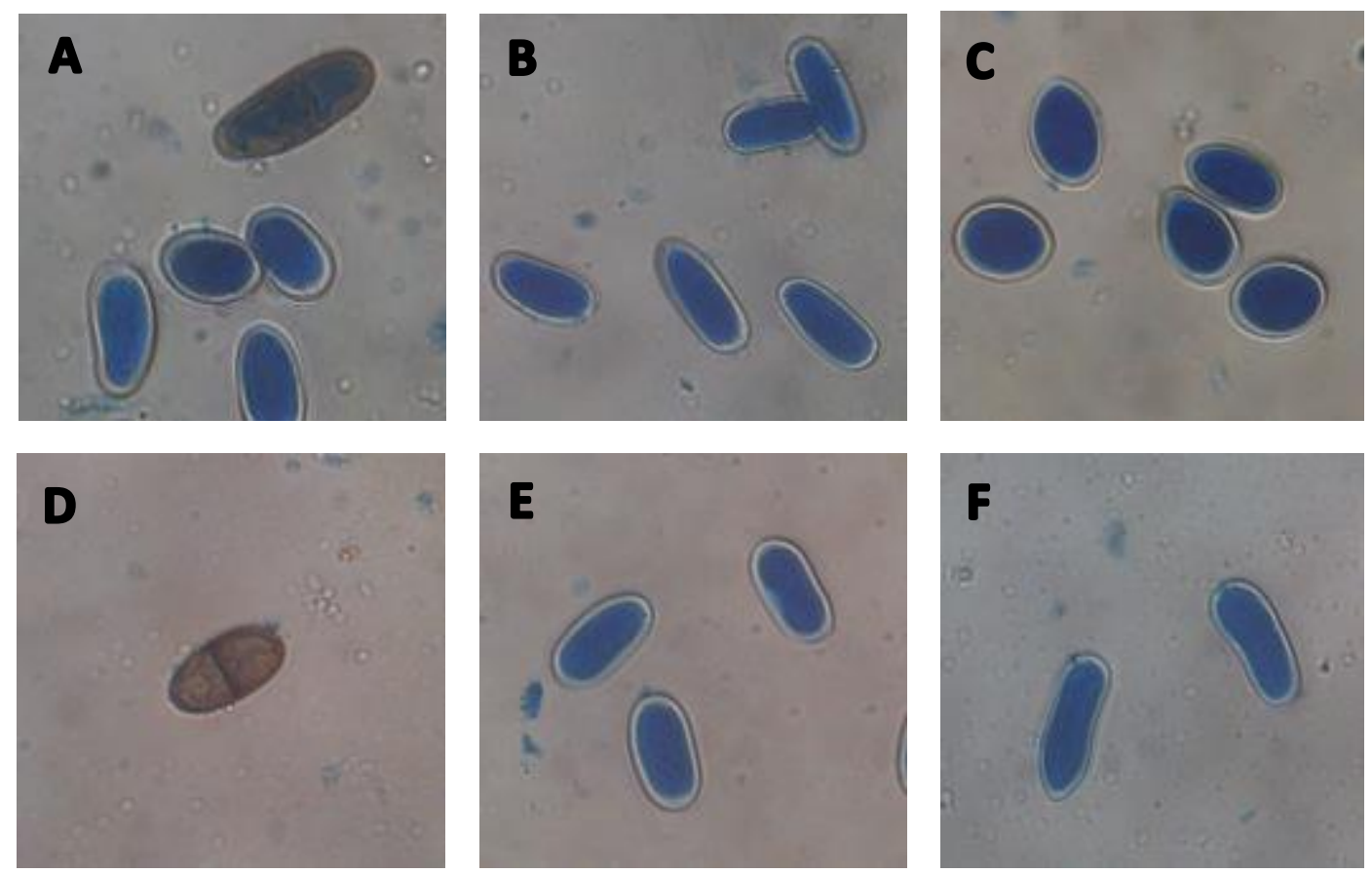

Figure 6: Morphological comparison of spores from $D c$ from A) CA, B) FL, C) WV, D) Italy, E) $D m$ from France; F) $D q$ from MA. Mountant is lactophenol + cotton blue. Spores shown at 40X magnification, not to scale.

Observed spore sizes were significantly different by location (p-value $<0.0001)$. $D c$ mean spore measurements from CA were the largest $(21.02 \pm 0.18 \mu \mathrm{m})$, followed by Spain $(20.38 \pm 0.14 \mu \mathrm{m}), \mathrm{MA}(19.93 \pm 0.22 \mu \mathrm{m}), \mathrm{WV}(19.61 \pm 0.22 \mu \mathrm{m}), \mathrm{FL}(19.42 \pm 0.18 \mu \mathrm{m}), \mathrm{ME}$ $(18.89 \pm 0.22 \mu \mathrm{m})$, Italy $(18.47 \pm 0.31 \mu \mathrm{m})$ and WI $(18.370 .31 \mu \mathrm{m})$, although sample size varied considerably (Figure 7). 


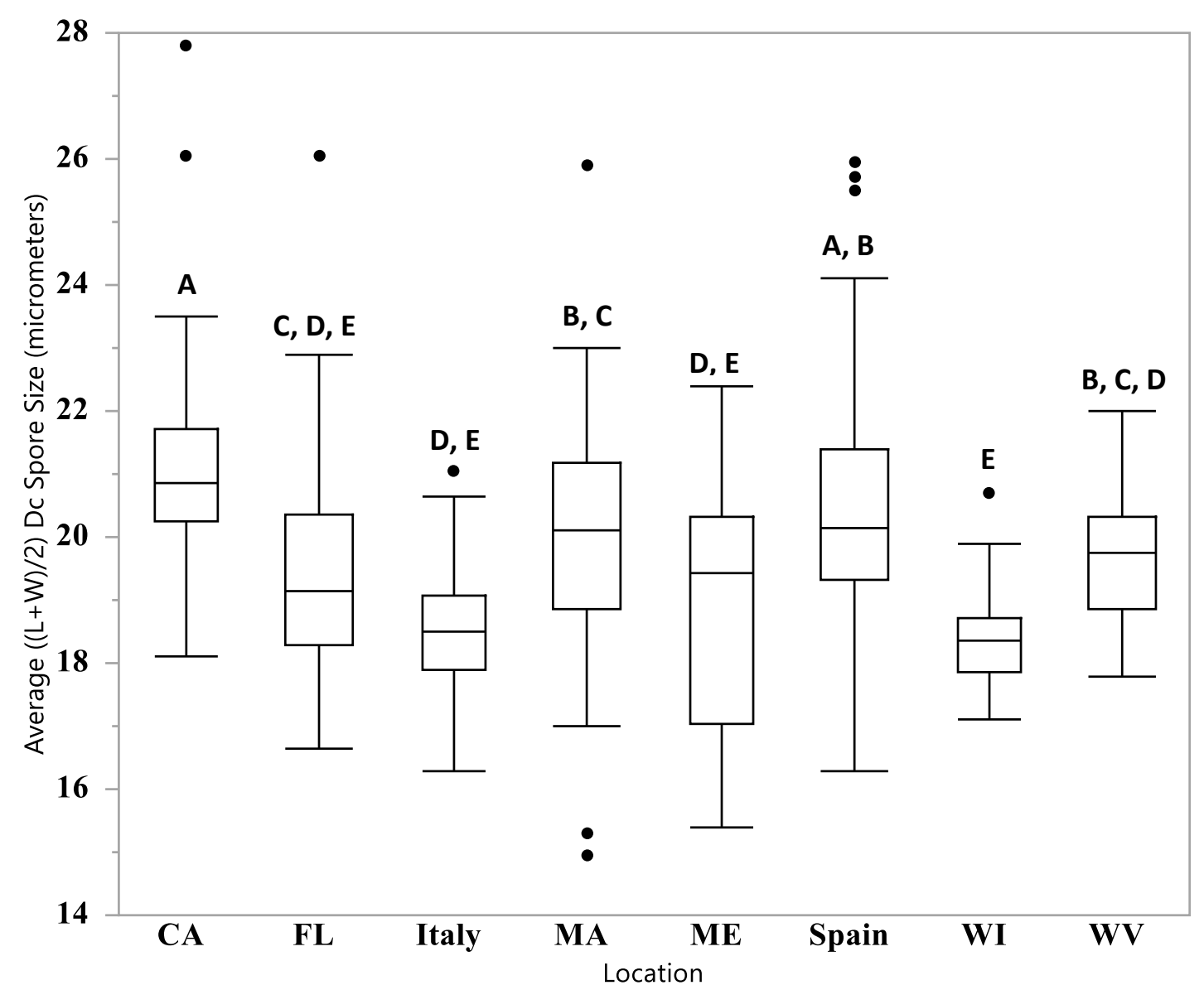

Figure 7: Box plots for average spore size ((Length One + Length Two)/2) of $D c$ isolates $(\mathrm{N}=$ $19)$ by location (state where isolate was retained from: CA $(n=3)$, FL $(n=3)$, Italy $(n=1)$, MA $(n=2)$, ME $(n=2)$, Spain $(n=5)$, WI $(n=1)$, and WV $(n=2)$. Spore sizes compared between species and among geographic location using ANOVA. Letter designation by Tukey Kramer's ordered letter report shows significant differences by location. Single points outside the upper and lower extremes represent outliers and were included in analysis.

Two isolates of $D q$ had spores averaging $19.78 \mu \mathrm{m}$ with a standard deviation of $1.70 \mu \mathrm{m}$. These spores were hyaline in color and elliptical to oblong in shape (Figure 6F). Some spores of $D q$ isolate DC114 were uniseptate but lacked pigment seen in other septate spores. Spores from MA were larger than the MD observed spores which measured $20.82 \pm 0.27 \mu \mathrm{m}$ and 18.73 $\pm 0.27 \mu \mathrm{m}$ respectively (Figure 8$)(\mathrm{p}$-value $<0.0001)$ 


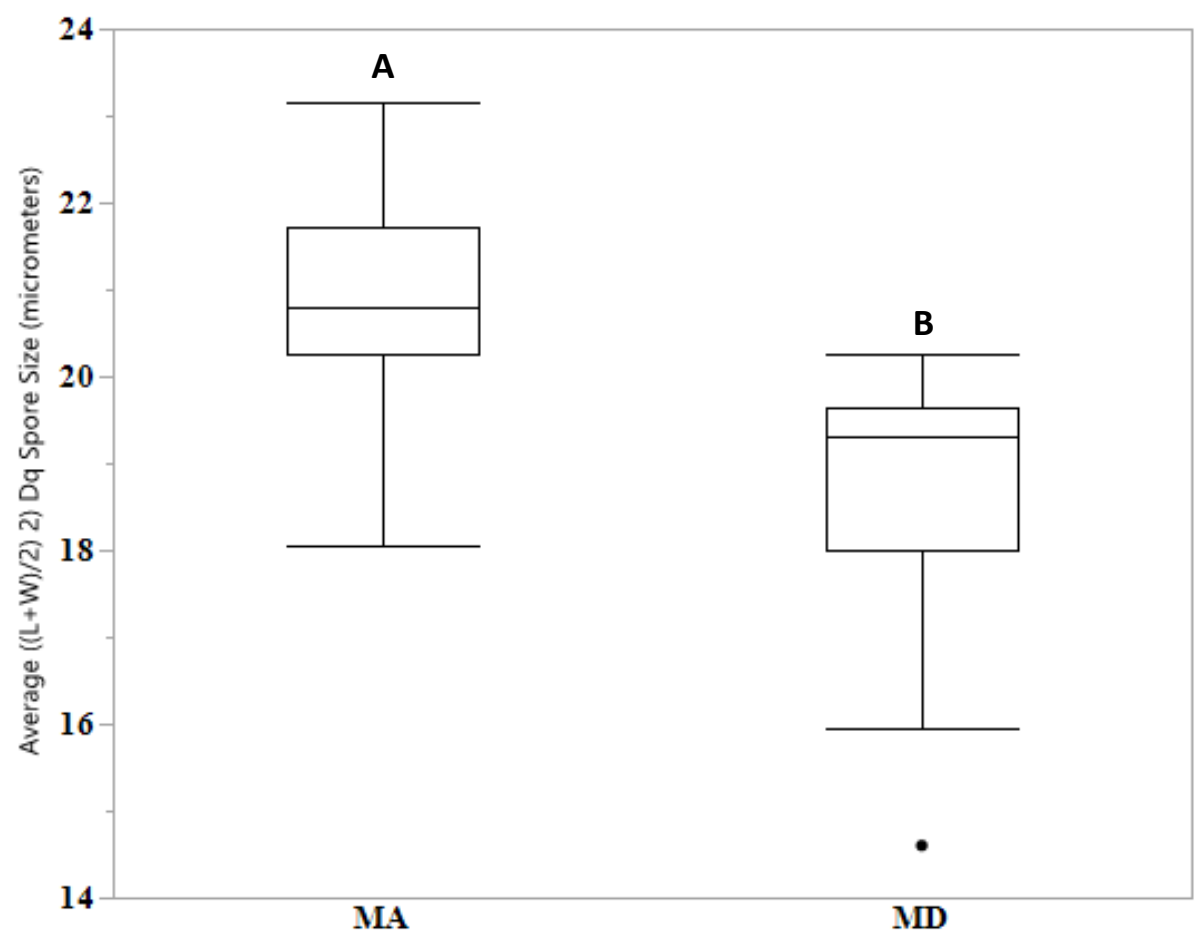

Figure 8: Box plots for average spore size ((Length One + Length Two)/2) of Dq isolates $(\mathrm{N}=2)$ by location (state where isolate was retained from: MA: $(n=1)$ and MD: $(n=1)$. Spore sizes compared between species and geographical location using ANOVA. Letter designation by Tukey Kramer's ordered letter report shows significant differences by location. Single points outside the upper and lower extremes represent outliers and were included in analysis.

Only one isolate of $\mathrm{Dm}$ was included in this study with observed an average spore size of $19.84 \mu \mathrm{m}$ with a standard deviation of $1.07 \mu \mathrm{m}$. These spores were hyaline in color and elliptical to oblong in shape (Figure 6E) and were not observed as being septate or dark in color.

\section{Colony Morphology On Specialized Media}

When grown on modified PNE, Diplodia isolates lost their characteristic fluffy greyishwhite growth with an irregular margin (Figure 5A), and instead grouped into one of several distinctive morphotypes (Figure 9). 


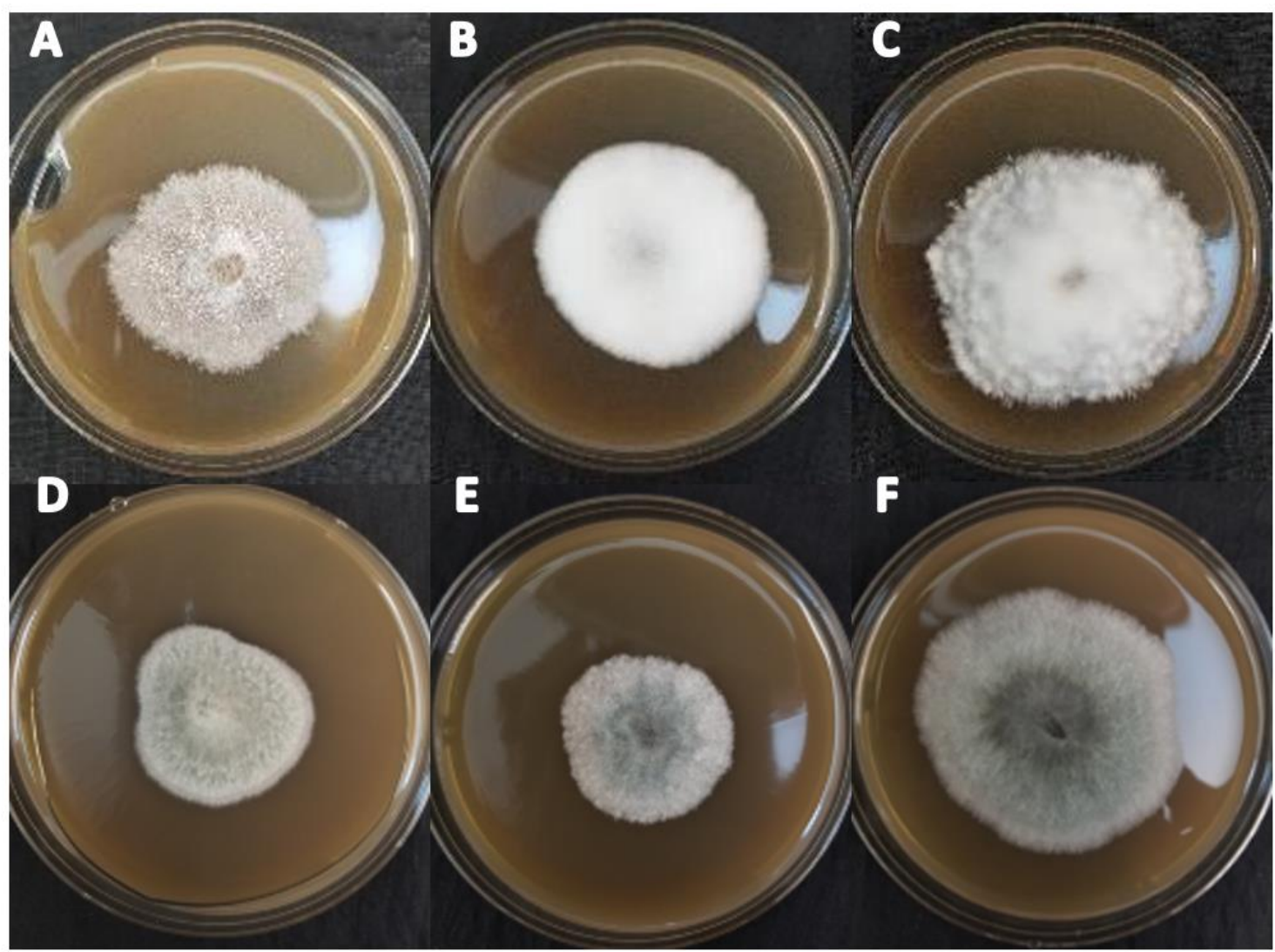

Figure 9: Diplodia spp. isolates grown on pine needle extract agar for two weeks. $D c$ morphology: A) morphotype 1, B) morphotype 2, C) morphotype 3, D) morphotype 4, E) morphotype 5; $D q$ morphology: F) morphotype 1 .

In the initial PNE assay, $D c$ isolates grouped into five morphotypes: 1) pink colonies with smooth margins lacking aerial mycelium (Figure 9A) from five cultures obtained from FL, WI, ME and MA; 2) densely tufted white colonies with a smooth margin (Figure 9B) from two isolates from CA; 3) white colony with rosetted margins (Figure 9C) from one isolate from Italy; 4) densely felty to woolly whitish-green colony with white smooth margins (Figure 9D) from one isolate from Spain; and 5) predominately white colonies with a light green hue (Figure 9E) from two isolates from CA and FL. Both $D q$ isolates from MA and MD formed greenish-gray colonies with irregular white margins and aerial mycelium (Figure 9F). 


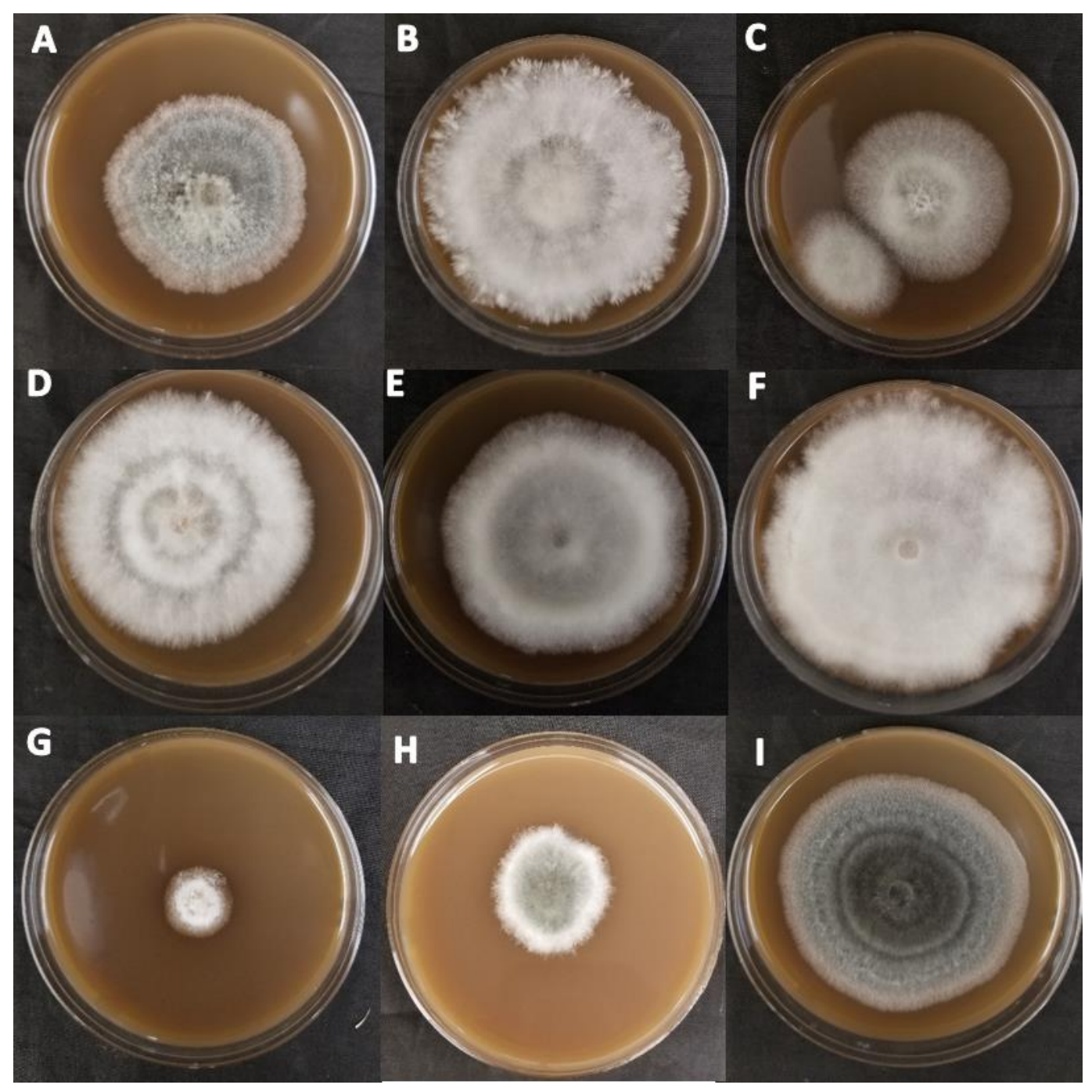

Figure 10: Diplodia spp. isolates grown on pine needle extract agar for two weeks. $D c$ morphology: A) morphotype 6, B) morphotype 7, C) morphotype 8, D) morphotype 9, E) morphotype 10, F) morphotype $11, \mathrm{G}$ ) morphotype 12 ; Dq morphology: H) morphotype 1, I) morphotype 2 .

In the second PNE assay, $14 D c$ isolates separated into 7 morphotypes not observed in the initial pairing: 6) green colonies with defined pink margins with aerial mycelium (Figure 10A) from two isolates from FL and MA; 7) white colony with thick branching marginal hyphae (Figure 10B) from one isolate from Italy; 8) densely felty to woolly whitish-green colony with white smooth margins (Figure 10C) from one isolate from Spain; 9) white colonies with target- 
shaped growth alternating between aerial and non-aerial hyphae (Figure 10D) from three isolates from WV and Spain; 10) predominately white colony with a light green hue (Figure 10E) from one isolate from CA; 11) white colonies with circular to wavy margins and aerial hyphae (Figure 10F) from five isolates from CA and Spain; and 12) small predominantly white colony with flat pink margins and aerial mycelium (Figure 10G) from one isolate from FL. One of the $D q$ isolates observed between MD and MA, differed from the original pairing. The MD isolate grew into a green colony with irregular white margins and aerial mycelium (Figure 10H), while the MA isolate grew into a blueish green colony with defined pink margins with aerial mycelium (Figure 10I).

\section{Discussion:}

Phylogenetic and morphological comparisons were made among $D c$ isolates collected from several countries in Europe, and several U.S. states. The results of this study reveal that many of the $D c$ isolates examined were not phylogenetically distinct (with strong bootstrap support) based on location or the gene regions studied.

Previous studies indicate that $D c$ may have been inadvertently introduced into the U.S. from areas in Europe, where $D c$ has been associated with cork oak decline since the early 2000s (Lynch et al. 2013). The results of our phylogenetic analysis provide strong support for linkages between isolates from CA and Spain based on EF-1 $\alpha$ ( $86 \%$ bootstrap support) and, to a lesser extent, the combined 3-gene dataset (58\%). These two regions are among the world's leading wine producers, both of which have a history of $D c$ causing disease on grapes (Vitis spp.) (Varela et al. 2011, Úrbez-Torres et al. 2010). This observation, along with similar individual spore sizes and morphology on specialized media, supports our hypothesis that $D c$ causing disease in CA 
may have been introduced from Spain. However, the LSU analysis contradicts findings based on EF-1 $\alpha$ in that it provides moderate support for two of Spain isolates grouping with isolates recovered from ME and FL. The addition of sequence data from other protein-coding genes could provide enhanced resolution of strains.

Ultimately, cross-pathogenicity studies are needed to compare isolates from Europe and the U.S. to better understand the host specificity and virulence of strains. Similar studies of oak wilt in European versus American oaks in common orchards in WV revealed high susceptibility of European white oak family members compared to limited susceptibility of U.S. white oak family members (MacDonald et al. 2001).

Morphological studies have also proven useful in describing and comparing species. Although congruence between morphological trends and phylogenetic groupings have been shown for several fungi, the number of isolates used in this study were not sufficient nor consistent enough to make meaningful comparisons between sampled locations. Spain had the most observed isolates $(n=5)$, followed by CA $(n=3)$ and FL $(n=3)$, with fewer counts for the other observed isolates. Spain and CA isolates exhibited the largest spores across all location examined, but larger trends based on these morphological features across $D c$ were not consistent or phylogenetically informative. Previous spore measurements were reported for several European isolates included in this study (Lynch et al. 2013, Alves et al. 2004). However, the quantity of spores measured per isolate, number of isolates observed, and locations of strains used were not reported.

Although the specific strains of $D c$ recovered from CA align with isolates from Spain and may indicate an introduction from Europe, the other states within the U.S. affected by $D c$ are 
more geographically isolated from international ports. However, reported U.S. states are mostly coastal, which could mean that $D c$ is acting opportunistically in areas that are more sensitive to the changing climate, or that $D c$ is being introduced in numerous locations due to imports from Europe. States including FL, MA and WV had overlapping spore and culture morphologies that were supported in the 3-gene concatenated tree, supporting the hypothesis that $D c$ is a native pathogen in the U.S. Spore sizes and comparisons of FL, MA and WV isolates have not been previously compared in literature. Similar European-U.S. groupings are apparent between Italy and WV isolates in both the EF-1 $\alpha$ tree and the 3-gene tree. However, the support for this clade is moderate (58\% bootstrap support) for both trees.

The low incidence of isolation coupled with the geographic overlap of documented declines support the observation that $D c$ is contributing to oak decline in both Mediterranean Europe and the U.S., however, is not likely the inciting agent of widespread mortality. To better understand if all isolates of $D c$ were introduced, or if the U.S. has its own native strains, a broader survey needs to be conducted from both symptomatic and asymptomatic trees and tissues in order to define the true geographic extent of this pathogen.

\section{Conclusion:}

Diplodia corticola has been implicated over the last couple decades in contributing to oak decline in Mediterranean Europe and the U.S. Previous studies indicated that this pathogen, although capable of causing disease in the absence of other pathogens in pathogenicity trials, is an opportunistic pathogen of oak trees, and acting in concert with other biotic and abiotic factors. Through the results of this study, I sought to clarify relationships among isolates from Europe and the U.S. and revealed limited genetic diversity among $D c$ isolates from different geographic 
locations. The intermixing of populations from both U.S. and Europe may indicate $D c$ is a cosmopolitan pathogen, present from oak on both continents. However, secondary introductions are still possible and may reflect some of the fine structure observed in both the EF-1 $\alpha$ tree and the 3-gene phylogeny. The occurrence of Diplodia outbreaks in geographically isolated regions, especially in more vulnerable coastal locations, may indicate that trees in these regions are more predisposed to secondary opportunistic pathogens. Further molecular studies, including more loci and comparative genomics, are needed to fully resolve differences among Diplodia isolates affecting oak worldwide. 


\section{References:}

Aćimović, S.G., Harmon, C.L., Bec, S., Wyka, S., Broders, K. and Doccola, J.J., 2016. First report of Diplodia corticola causing decline of red oak (Quercus rubra) trees in Maine. Plant Disease, 100(3), p.649.

Alves, A., Correia, A., Luque, J. and Phillips, A., 2004. Botryosphaeria corticola, sp. nov. on Quercus species, with notes and description of Botryosphaeria stevensii and its anamorph, Diplodia mutila. Mycologia, 96(3), pp.598-613.

Bragança, H., Neno, J., Henriques, J., Diogo, E. and Alves, A., 2016. First report of Diplodia quercivora causing dieback on Quercus suber and in Europe. Plant Disease, 100(10), pp.21662166.

Brasier, C.M. and Scott, J.K., 1994. European oak declines and global warming: a theoretical assessment with special reference to the activity of Phytophthora cinnamomi.EPPO Bulletin, 24(1), pp.221-232.

da Clara, M.I.E. and de Almeida Ribeiro, N.M.C., 2013. Decline of Mediterranean oak trees and its association with Phytophthora cinnamomi: a review. European Journal of Forest Research, 132(3), pp.411-432.

Corkforest-Blogger. "Harvesting the Cork Oak." Cork Forest Conservation Alliance, 3 May 2015, www.corkforest.org/harvesting-the-cork-oak/.

Dreaden, T.J., Shin, K. and Smith, J.A., 2011. First report of Diplodia corticola causing branch cankers on live oak (Quercus virginiana) in Florida. Plant disease, 95(8), pp.1027-1027.

Dreaden, T.J., Black, A.W., Mullerin, S. and Smith, J.A., 2014. First report of Diplodia quercivora causing shoot dieback and branch cankers on live oak (Quercus virginiana) in the United States. Plant disease, 98(2), pp.282-282.

Haines, S.L., Stauder, C.M., Martin, D.K.H., Thompson, B.A. and Kasson, M.T., 2019. First Report of Diplodia quercivora Causing Stem Cankers on Chestnut Oak (Quercus montana) in Maryland. Plant Disease, 103(6), p.1423.

Jacobi, W.R. and MacDonald, W.L., 1980. Colonization of resistant and susceptible oaks by Ceratocystis fagacearum. Phytopathology, 70(7), pp.618-623.

Keča, N., Koufakis, I., Dietershagen, J., Nowakowska, J.A. and Oszako, T., 2016. European oak decline phenomenon in relation to climatic changes. Folia Forestalia Polonica, 58(3), pp.170177.

Kumar, S., Stecher, G. and Tamura, K., 2016. MEGA7: molecular evolutionary genetics analysis version 7.0 for bigger datasets. Molecular biology and evolution, 33(7), pp.1870-1874. 
Lazzizera, C., Frisullo, S., Alves, A. and Phillips, A.J.L., 2008. Morphology, phylogeny and pathogenicity of Botryosphaeria and Neofusicoccum species associated with drupe rot of olives in southern Italy. Plant Pathology, 57(5), pp.948-956.

Linaldeddu, B.T., Maddau, L. and Franceschini, A., 2017. First Report of Diplodia corticola Causing Canker and Dieback of Quercus ilex, Q. petraea, and Q. suber in Corsica (France). Plant Disease, 101(1), pp.256-256.

Linaldeddu, B.T., Scanu, B., Maddau, L. and Franceschini, A., 2014. Diplodia corticola and Phytophthora cinnamomi: the main pathogens involved in holm oak decline on Caprera Island (Italy). Forest Pathology, 44(3), pp.191-200.

Lynch, S.C., Eskalen, A., Zambino, P.J., Mayorquin, J.S. and Wang, D.H., 2013. Identification and pathogenicity of Botryosphaeriaceae species associated with coast live oak (Quercus agrifolia) decline in southern California. Mycologia, 105(1), pp.125-140.

Lynch, S.C., Eskalen, A., Zambino, P. and Scott, T., 2010. First report of bot canker caused by Diplodia corticola on coast live oak (Quercus agrifolia) in California. Plant disease, 94(12), pp.1510-1510.

MacDonald, W.L., Pinon, J., Tainter, F.H. and Double, M.L., 2001. European oaks-susceptible to oak wilt. Shade Tree Wilt Diseases. APS Press, St. Paul, MN, pp.131-137.

Martin, D.K.H., Turcotte, R.M., Miller, T.M., Munck, I.A., Aćimović, S.G., Macias, A.M., Stauder, C.M. and Kasson, M.T., 2017. First report of Diplodia corticola causing stem cankers and associated vascular occlusion of northern red oak (Quercus rubra) in West Virginia. Plant Disease, 101(2), pp.380-380.

Martin Danielle, K., and Isabel Munck. "Pest Alert Diplodia Corticola "Bot Canker" of Oak" NA-PR-01-17, U.S. Department of Agriculture, Forest Service, Northeastern Area State and Private Forestry, April 2017

Munck, Isabel. 2017 “ Pest Alert Oak Wilt in the Northeastern United States”, NA-PR-02-17, U.S. Department of Agriculture, Forest Service, Northeastern Area State and Private Forestry, July 2017.

Reed, S.E., English, J.T., Lalk, S.R. and Tosie, K.M., 2018. First report of Diplodia corticola causing stem and branch cankers on white oak (Quercus alba) in Missouri, USA. Plant disease, 102(12), p.2657.

Smith, D.R. and Stanosz, G.R., 2018. Occurrence of Diplodia corticola, including new oak host records, in Wisconsin, USA. Forest pathology, 48(4), p.e12427.

Slippers, B., Boissin, E., Phillips, A.J.L., Groenewald, J.Z., Lombard, L., Wingfield, M.J., Postma, A., Burgess, T. and Crous, P.W., 2013. Phylogenetic lineages in the Botryosphaeriales: a systematic and evolutionary framework. Studies in Mycology, 76, pp.31-49. 
Úrbez-Torres, J.R., Peduto, F., Rooney-Latham, S. and Gubler, W.D., 2010. First report of Diplodia corticola causing grapevine (Vitis vinifera) cankers and trunk cankers and dieback of canyon live oak (Quercus chrysolepis) in California. Plant disease, 94(6), pp.785-785.

Varela CP, Fernández VR, Casal OA, Vázquez JM. First report of cankers and dieback caused by Neofusicoccum mediterraneum and Diplodia corticola on grapevine in Spain. Plant disease. 2011 Oct;95(10):1315-.

Villesen, P., 2007. FaBox: an online toolbox for fasta sequences. Molecular ecology notes, 7(6), pp.965-968.

Su, Y.Y., Qi, Y.L. and Cai, L., 2012. Induction of sporulation in plant pathogenic fungi. Mycology, 3(3), pp.195-200. 


\section{Appendix:}

Table 1: Isolate name and associated GenBank gene ID:

\begin{tabular}{|c|c|c|c|c|}
\hline \multicolumn{5}{|c|}{} \\
\hline Isolate & Additional ID & ITS & EF1 & LSU \\
\hline CJL155 & CBS112071 & AY259107 & TBD & TBD \\
\hline CJL245 & CBS112072 & AY259108 & TBD & TBD \\
\hline CJL248 & CBS112073 & TBD & TBD & TBD \\
\hline CJL255 & - & TBD & TBD & TBD \\
\hline CJL338 & CBS112547 & TBD & TBD & TBD \\
\hline CJL364 & - & TBD & TBD & TBD \\
\hline CJL374 & - & TBD & TBD & TBD \\
\hline CJL47 & CBS678.88 & AY259104.1 & GU799459.1 & TBD \\
\hline DC103 & QURU O 10 & KX766145.1 & TBD & TBD \\
\hline DC105 & QURU2 R & TBD & TBD & TBD \\
\hline DC110 & B012 & TBD & TBD & TBD \\
\hline DC113 & HR 25-1-1 & TBD & TBD & TBD \\
\hline DC114 & WHG PRKL-1-5 & TBD & TBD & TBD \\
\hline DC117 & OTL181 & KT427391 & TBD & TBD \\
\hline DC118 & OTCT3-1 & KT427389 & TBD & TBD \\
\hline DQ703 & MK160499 & TBD & TBD & TBD \\
\hline PL1447 & MTF11 AB & TBD & TBD & TBD \\
\hline PL1480 & SVH1 AB & TBD & TBD & TBD \\
\hline PL1518 & OSC3 B1 AB & TBD & TBD & TBD \\
\hline UCR1246 & JN693501 & TBD & JQ512108.1 & TBD \\
\hline UCR1339 & JQ411401 & JQ411401.1 & JQ512110.1 & TBD \\
\hline UCR488 & JN6693501 & TBD & JQ512132.1 & TBD \\
\hline WI 03-35 & - & MG220435.1 & TBD & TBD \\
\hline
\end{tabular}




\title{
Chapter Three: Geographic, Morphological and Phylogenetic Distribution of Diplodia spp. In Oak Forests Across the Mid-Atlantic U.S.
}

\begin{abstract}
:
In the Mid-Atlantic region of the U.S., where mixed hardwoods are the predominant forest cover type, oak species (Quercus spp.) have been in a state of in a state of declining health and vigor for the past several decades. Historically, several pathogens have contributed to this decline to varying degrees including Bretziella fagacearum, the causal agent of oak wilt and Phytophthora cinnamomi, the causal agent of Phytophthora root rot, as well as various insect defoliators and abiotic agents. More recently, Diplodia corticola (Dc) and Diplodia quercivora $(D q)$, both emerging canker pathogens, have been implicated in causing dieback and mortality of red and white oak species in the eastern United States. To determine the range and impact of these two pathogens on forest health, a fungal survey was conducted in 2019 across the MidAtlantic region, including Maryland, Pennsylvania, Virginia and West Virginia. 563 oak trees comprising both red and white oak family members were evaluated across 33 forests spanning 18 counties. A total of 32 Diplodia isolates encompassing three Diplodia spp. were recovered from 13 of the 18 sampled counties from a total of 5,335 sampled bark plugs. Despite the high incidence of Diplodia-positive counties, the overall recovery of Diplodia spp. from sampled plugs was extremely low, possibly due, in part, to the inhibitory effects of commonly recovered Penicillium spp. and Pestalotiopsis spp. on Diplodia growth as was demonstrated via inhibition assays. Diplodia species recovered included $D c, D q$, and $D$. sapinea $(D s)$, as well as Botryosphaeria dothidea $(B d)$, another close relative in the Botryosphaeriaceae family. Both $D c$ and $D s$ were recovered from red and white oak family members, whereas $D q$ was exclusive to
\end{abstract}


white oak family members and $B d$ to red oak family members. Of these species $D c$ was most frequently isolated followed by $D q, D s$, and $B d$. Overall, external symptoms associated with Diplodia canker and mortality were relatively low across all sampled counties, with white oak family members exhibiting more dieback but less outward bole symptoms on average compared to red oak family members. Although previously shown to be associated with severe dieback and mortality events, Diplodia spp. recovered during this survey did not appear to be inciting oak decline across the region during the window in which these surveys were conducted. These results indicate that Diplodia spp. reside in both asymptomatic and symptomatic tissues and may be acting opportunistically in favorable environments.

\section{Introduction:}

In the Mid-Atlantic region, where mixed hardwoods are the predominant forest cover type, oak species (Quercus spp.) have been in a state of declining health and vigor decline for the past several decades, although the distribution of this decline is heterogeneous across the landscape (Oak et al. 2016). Several pathogens have been found to contribute to this decline to varying degrees including Bretziella fagacearum, the causal agent of oak wilt (MacDonald et al. 2001, Jacobi and MacDonald 1980, Amos and True 1967, Shigo, A.L., 1958), Phytophthora cinnamomi, the causal agent of Phytophthora root rot (McConnell and Balci 2014), and various insect defoliators including gypsy moth (Lymantria dispar) (Tiberi et al. 2016, Asaro and Chamberlin 2015). Affected trees show one or a combination of outward symptoms including acute wilt, blighted leaves, external cankers, necrotic lesions, severe dieback, and in advanced stages, mortality. (Reed et al. 2018, Smith and Santosz 2018, Martin et al. 2017, Munck et al. 2017, Martin and Munck 2017, Aćimović et al. 2016, Dreaden et al. 2011, Lynch et al. 2010). Abiotic stresses including drought, flooding, competition, and mechanical damage have also 
attributed to reduced vigor in native oak forests, which likely predisposes trees to infections by various opportunistic fungi and oomycetes (Bostock et al. 2014, Schomaker et al. 2007).

More recently, Diplodia spp., a genus associated with "bot canker" diseases of various angiosperm hosts, have been implicated in causing disease in red and white oak family members in the U.S. This follows closely behind detections of $D c$ across Europe and its association with regional oak decline in Spain, Portugal, France and Italy (Linaldeddu et al. 2017, Lazzizera et al. 2008, Alves et al. 2004). In both the U.S. and Europe, outward symptoms include premature leaf browning, leaf drop, crown dieback and bole and/or branch cankers (Reed et al. 2018, Smith and Santosz 2018, Martin et al. 2017, Munck et al. 2017, Martin and Munck 2017, Aćimović et al. 2016, Dreaden et al. 2011, Lynch et al. 2010). Internally, $D c$ has also been associated with vascular occlusion and cambium streaking (Martin et al. 2017).

Initial detections of $D c$ causing disease on oaks in the U.S. were first reported from California on coastal live oak (Quercus agrifolia) with symptomatic trees dating back to the early 2000s (Lynch et al. 2010). The fungus has since been recovered from both red and white oak family members including red oak (Q. rubra), black oak (Q. velutina), bur oak $(Q$. macrocarpa), southern live oak (Q. virginiana), coast live oak (Q. agrifolia) and white oak $(Q$. alba) beginning in the early 2000s (Reed et al. 2018, Smith and Santosz 2018, Martin et al. 2017, Munck et al. 2017, Martin and Munck 2017, Aćimović et al. 2016, Dreaden et al. 2011, Lynch et al. 2010). As of 2019, Dc has been documented affecting oak trees to varying degrees in Washington D.C. (Smith and Stanosz 2018) and eight U.S. states including California (Lynch et al. 2010), Florida (Dreaden et a. 2011), Maine (Aćimović et al. 2016), Massachusetts (Munck et al. 2017), Missouri (Reed et al. 2018), Pennsylvania (Martin and Munck 2017), West Virginia (Martin et al. 2017) and Wisconsin (Smith and Santosz 2018). Although present in these states, 
$D c$ observations are often isolated reports and have not been implicated in a rise of widespread mortality across the region.

In fall 2018, initial sampling for $D c$ was conducted in WV and MD in areas of reported oak dieback and blight to gather baseline data for 2019 surveys. Areas of reported blight and dieback based on feedback from local state foresters and natural resources personnel included Pen Mar Park in Washington County, MD and Green Ridge State Forest in Allegany County, MD, High Rock Camp and Watoga State Park in Pocahontas County, WV and Coopers Rock State Forest in Monongalia County, WV. Fungal sampling and isolation from destructively sampled cross-sections confirmed $D c$ in High Rock Camp and Coopers Rock State Park, and Diplodia quercivora $(D q)$ in Green Ridge State Forest. This was the first confirmation of $D q$ causing disease on white oak family members in the Mid-Atlantic region (Haines et al. 2019). In addition to being confirmed from $Q$. montana in $\mathrm{MD}$, detections of $D q$ on white oak family members in the U.S. have also been reported for southern live oak (Q. virginiana) in FL (Dreaden et al. 2014). The apparent lack of host specificity and broad geographic distribution of $D c$ on both red and white oak family members informed our initial hypothesis that $D c$ was a generalist cosmopolitan pathogen while $D q$ has a more limited geographic range and is restricted to white oak family members.

These findings also raised important questions about the larger decline patterns across the landscape that had been casually observed but inadequately addressed, prompting a closer look at the USDA Forest Service's Forest Inventory Analysis (FIA) data. Given the higher incidence of $D c$ from targeted sampling locations in 2018 coupled with the high numbers of $D c$ detections on red oak family members in literature, we used the EVALIDator Web application to delimit annual mortality rates of red oaks by county (annual mortality volume/live volume) for the entire 
Mid-Atlantic region (data not shown). The resulting output provided county level resolution of mortality with at least 16 counties across DE, NJ, PA, VA, WV with 5.1-17.4\% annual mortality, the remaining with $<5 \%$ mortality.

To better understand the geographic extent and impact of $D c$ and $D q$ on forest health, a regional survey was conducted in 2019 in four states in Mid-Atlantic region. Sampling was stratified across mortality classes to explore the possible contributions of Diplodia spp. in stands and counties with varying levels of mortality.

\section{Methods:}

\section{$\underline{\text { Site Selection }}$}

Sampled counties were randomly selected based on USDA Forest Service FIA data on red oak mortality generated using the EVALIDator Web application (https://apps.fs.usda.gov/Evalidator/evalidator.jsp). The available FIA data separated countylevel oak mortality into four distinct levels: $<1 \%$ mortality (blue), $1.1-2.5 \%$ mortality (green), 2.6-5\% mortality (yellow) and 5.1-17.4\% mortality (red). Using a random number generator, one county from each mortality level was selected in MD, PA, VA and WV (Figure 1). In MD, these counties included Worcester (blue), Howard (green), Garrett (yellow) and Fredrick (red). In PA, selected counties included Monroe (blue), Bucks (green), Perry (yellow) and Juniata (red). In VA, this included Appomattox (blue), Rockbridge (green), Henrico (yellow) and Prince William (red). In WV, this included Randolph (blue), Braxton (green), Wayne (yellow) and Barbour (red) (Figure 1). 


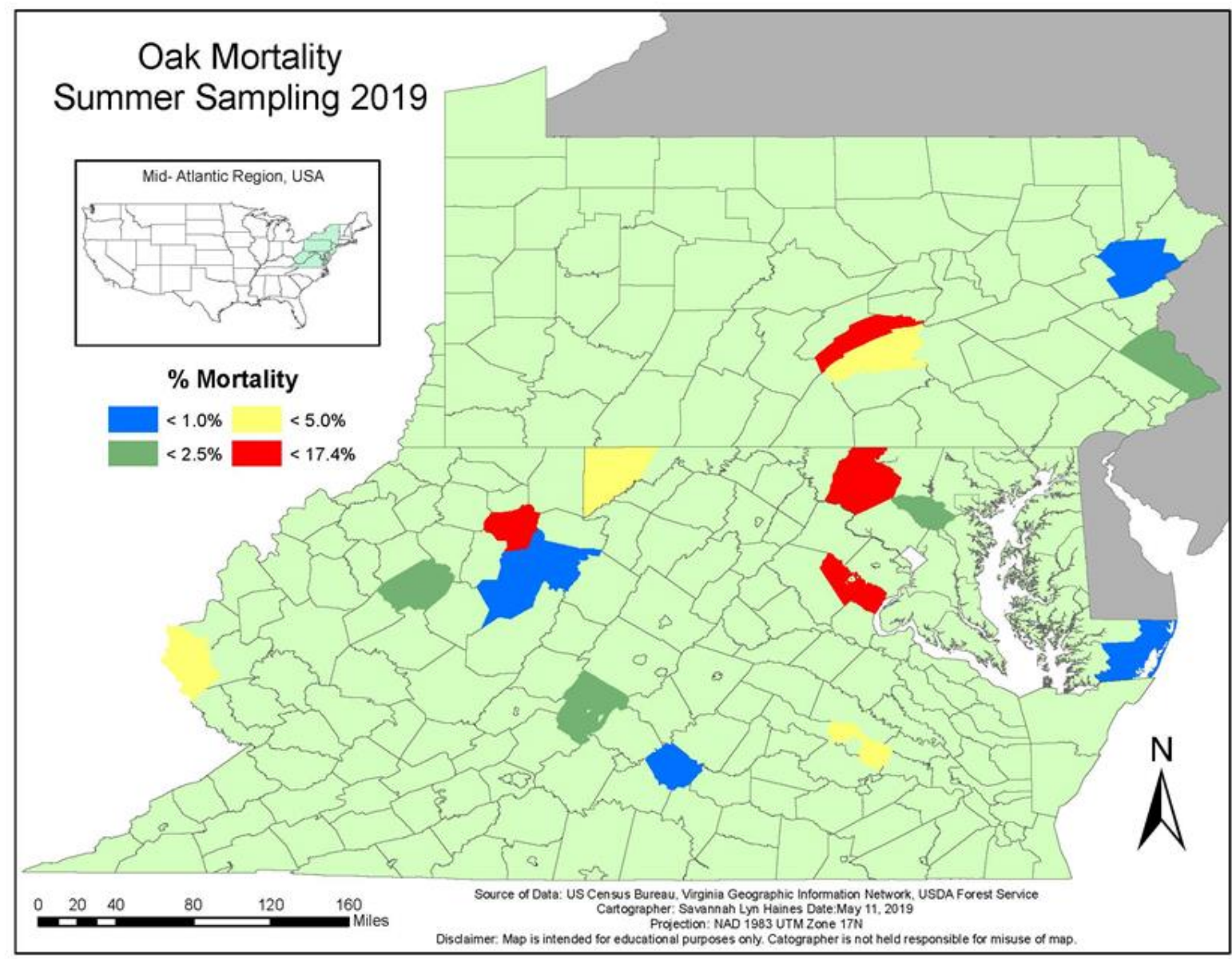

Figure 1: Oak Mortlity Summer Sampling 2019 Map. Colored counties represent each \% Mortality level of intrest (blue: $<1 \%$ mortality, green: $1.1-2.5 \%$ mortality, yellow: $2.6-5 \%$ mortality and red: 5-17.4\% mortality in the four selected states (MD, PA, WV, VA)) in the lower Mid-Atlantic Region.

Two geographically separated forests in each of the selected counties were chosen based on oak presence, permissibility, accessibility and ownership. All privately held lands and predominantly softwood stands were excluded from the forest selection. Counties that did not have two forests that could meet that criteria were still included, but 30 trees were sampled in one forest, instead of the target of 15 trees per forest. For counties where these criteria were lacking a single forest, the next randomly selected county for that specific mortality class was used. 
These efforts resulted in sampling 31 forests in 16 counties. In MD, sampled forests included two state forests, four state parks, and one Environmental Area. In PA, sampled forests included one state forest, four state parks, and two state game lands. In VA, forests included two state forests, three parks and three wildlife management areas. In WV, forests included one state forest, one state park, five wildlife management areas and one national forest. For a detailed list of these locations see Table 1. 
Table 1: Sampled locations per county and mortality level for each state.

\begin{tabular}{|c|c|c|c|}
\hline State & County & $\begin{array}{c}\text { FIA } \\
\text { Mortality }\end{array}$ & Forests Sampled \\
\hline MD & Worcester & $<1 \%$ & Pocomoke State Forest \\
\hline \multirow{2}{*}{ MD } & \multirow{2}{*}{ Howard } & \multirow{2}{*}{$<2.5 \%$} & Patapsco Valley State Park \\
\hline & & & Middle Patuxent Environmental Area \\
\hline \multirow{2}{*}{ MD } & \multirow{2}{*}{ Garrett } & \multirow{2}{*}{$<5 \%$} & Garrett State Forest \\
\hline & & & Deep Creek Lake State Park \\
\hline \multirow{2}{*}{$\mathrm{MD}$} & \multirow{2}{*}{ Fredrick } & \multirow{2}{*}{$<17.4 \%$} & Gambrill State Park \\
\hline & & & South Mountain State Park \\
\hline \multirow{2}{*}{ PA } & \multirow{2}{*}{ Monroe } & \multirow{2}{*}{$<1 \%$} & Big Pocono State Park \\
\hline & & & State Game Lands \#38 \\
\hline \multirow{2}{*}{ PA } & \multirow{2}{*}{ Bucks } & \multirow{2}{*}{$<2.5 \%$} & Tyler State Park \\
\hline & & & Nockamixon State Park \\
\hline \multirow{2}{*}{ PA } & \multirow{2}{*}{ Perry } & \multirow{2}{*}{$<5 \%$} & Tuscarora State Forest \\
\hline & & & Little Buffalo State Park \\
\hline \multirow{2}{*}{ PA } & \multirow{2}{*}{ Juniata } & \multirow{2}{*}{$<17.4 \%$} & State Game Land \#215 \\
\hline & & & Small area of Tuscarora State Forest \\
\hline \multirow{2}{*}{ VA } & \multirow{2}{*}{ Appomattox } & \multirow{2}{*}{$<1 \%$} & Appomattox-Buckingham State Forest \\
\hline & & & Featherfin Wildlife Management Area \\
\hline \multirow{2}{*}{ VA } & \multirow{2}{*}{ Rockbridge } & \multirow{2}{*}{$<2.5 \%$} & Glenn Maury Park \\
\hline & & & Goshen Wildlife Management Area \\
\hline \multirow{2}{*}{ VA } & \multirow{2}{*}{ Henrico } & \multirow{2}{*}{$<5 \%$} & Four Mile Creek Park \\
\hline & & & Deep Bottom Park \\
\hline \multirow{2}{*}{ VA } & Prince & $<174 \%$ & Merrimac Farm Wildlife Management Area \\
\hline & William & $<17.4 \%$ & Conway Robinson State Forest \\
\hline WV & Pandolnh & $<10 \%$ & Monongahela National Forest \\
\hline$w v$ & Kandoıрn & $-1 \%$ & Kumbrabow State Forest \\
\hline WV & Proxton & $250 \%$ & Burnsville Lake Wildlife Management Area \\
\hline$w v$ & Draxion & $2.5 \%$ & Elk River Wildlife Management Area \\
\hline WV & Wayne & $<50$ & East Lynn Wildlife Management Area \\
\hline$w v$ & Wayne & $-5 \%$ & Beech Fork Lake Wildlife Management Area \\
\hline WV & Barbour & $<1740 \%$ & Teter Creek Lake Wildlife Management Area \\
\hline & & & Audra State Park \\
\hline
\end{tabular}


In addition to the 16 randomly selected counties stratified by mortality class, two forests were targeted for fungal isolation to serve as a follow-up to the 2016 and 2018 first reports. These sites included Green Ridge State Forest in Allegany County, MD, and Seneca State Forest in Pocahontas County, WV. Both forests had a history of oak decline and Diplodia presence, with Green Ridge State Forest being the site of the first report of $D q$ in MD (Haines et al. 2019) and Seneca State Forest being the site of the first report of $D c$ in WV (Martin et al. 2017).

Using publicly available forest boundary shapefiles, a random plot generator was used to create 30 labeled geographical coordinates (plots) per forest for each of the 33 forests. For forests that spanned more than one county, the shapefiles were clipped to only include the county of interest before plots were generated (Figure 2). Plots in an individual forest were selected by their assigned number and their accessibility. Lower numbered plots were prioritized however, due to the randomized nature of this design, some lower number plots were not accessible and had to be skipped. 


\section{Beech Fork Wildlife Management Area Field Plots}

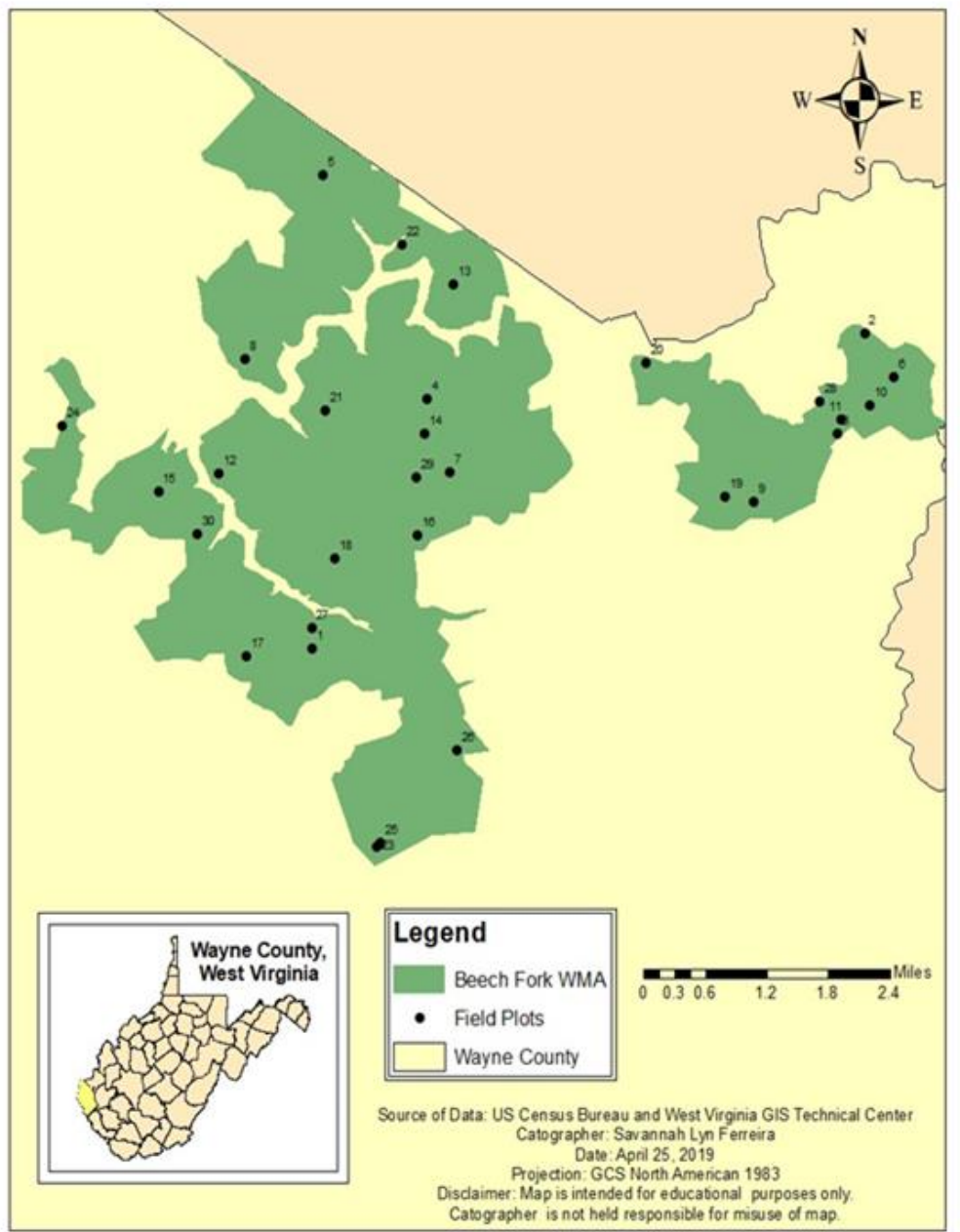

Figure 2: Sample map depicting field plots for Beech Fork Wildlife Management Area in Wayne County, WV.

\section{Field Sampling}

At each of the 33 forests, the randomly generated plots were used to establish plot center for sampling using variable radius plots. Due to inaccessible terrain, plot center was established up to 0.32 kilometers from plot center if the true plot center could not be accessed safely. At plot center, a 10 basal area factor prism was used to identify which trees were categorized as "in trees", then tree species, DBH (diameter at breast height) and crown class were recorded. For all 
recorded oak trees, additional observations were made including the dieback rating (Figure 3) and count of symptomatic tissue (cankers and necrotic "sooty" lesions) present (Figure 4). Crown dieback ratings consisted of 5 categories: 1: 0-24\% dieback, 2: 25-49\% dieback, 3: 5074\% dieback, 4: 75-99\% dieback and 5: 100\% dieback (dead). Symptomatic tissues were counted and categorized into 6 classes: $0=$ no outward symptoms, $1=1-3$ visible cankers, $2=4-6$ visible cankers, $3=7-9$ visible cankers, $4=$ more than 9 visible cankers, $N A=$ not applicable because it is so dead. All observed dieback ratings were compared between oak family, canopy class and outward symptoms classes using chi-square's likelihood-ratio statistic.
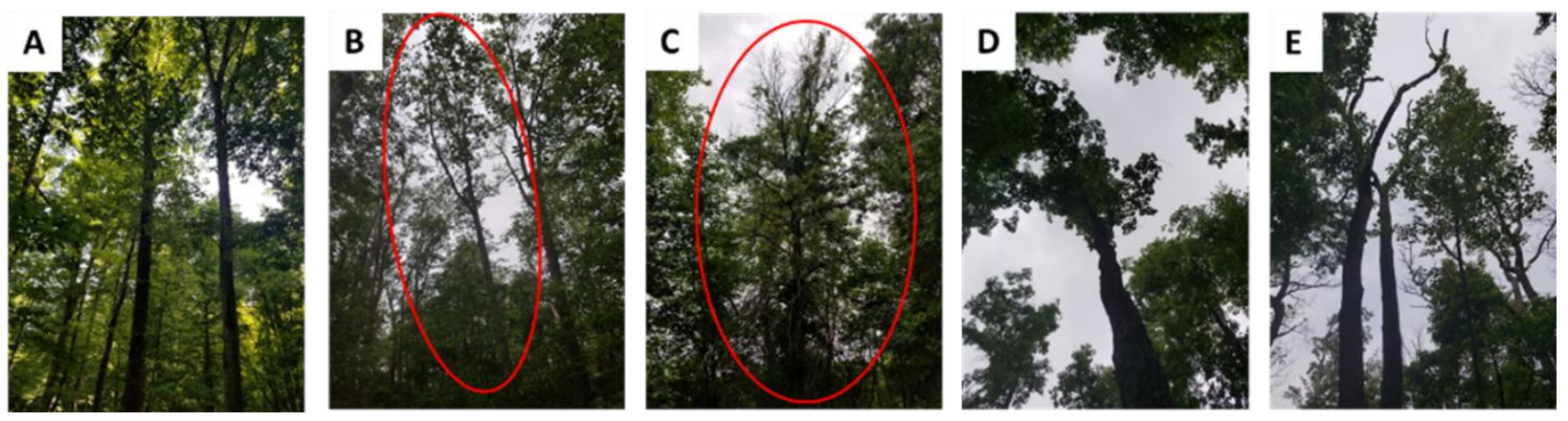

Figure 3: Progression of dieback in sampled oaks: A) 0-24\%, B) 25-49\%, C) 50-74\%, D) 75 $99 \%$, E) $100 \%$.

For the oak trees present within the $10 \mathrm{BAF}$ prism plot, a bone marrow extractor was used to microsample the main bole of the tree for fungal isolation. This extractor penetrates the tree (approx. 1- $2 \mathrm{~mm}$ ) to capture vascular cambium with a small 0.5-1 $\mathrm{mm}$ diameter extractor. A total of eight plugs were sampled per asymptomatic tree and placed in 96-well microtiter plates for subsequent processing; four were taken at DBH in the cardinal directions, and four were taken at approximately soil level in the cardinal directions. If the tree is outwardly symptomatic with necrotic/sooty lesions, and/or cankers (Figure 4A-D), an additional eight bark plugs were taken in and around the symptomatic tissue. The extractor was flame sterilized 
between symptomatic tissue and asymptomatic tissue on a singular tree as well as between trees.

This resulted in a maximum of 16 bark plugs being collected per tree, with 15 trees being sampled per forest. Diplodia presence and Diplodia species obatined were compared to oak family using chi-square's likelihood-ratio statistic.

If the $10 \mathrm{BAF}$ prism plot did not yield 15 oak trees, the next plot that met accessibility and numeric criteria would be sampled, until 15 oak trees in the forest were micro-sampled. In total, 30 oak trees were sampled evenly across two forests per county with two exceptions. Due to access limitations in Beech Fork Wildlife Management Area in Wayne County, WV, and the Monongahela National Forest in Randolph County, WV, 13 trees and seven trees were microsampled respectfully, resulting in Wayne County having 30 total sampled trees and Randolph county having only 27 sampled trees. All observed outward symptoms were compared between oak family and dieback ratings using chi-square's likelihood-ratio statistic.

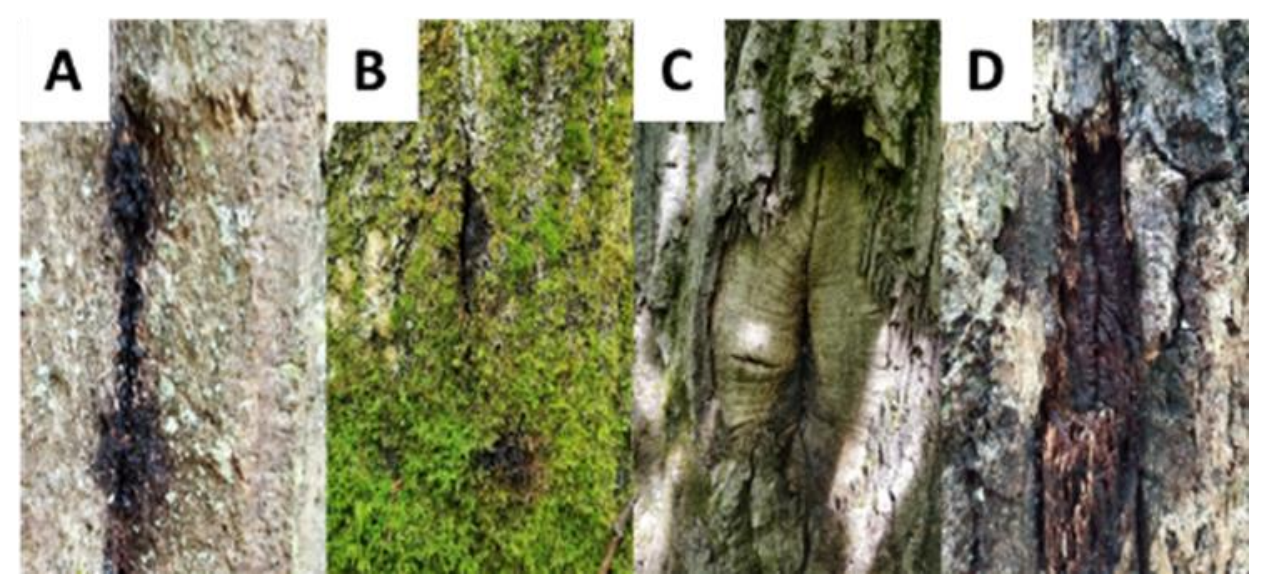

Figure 4: Examples of symptomatic tissue that would be sampled for Diplodia spp. infection. AB) Sooty lesions C-D) External cankers. 


\section{$\underline{\text { Sample Processing and Fungal Isolation }}$}

Bark plugs that were collected from the field were surface disinfested and plated for fungal isolation. The plugs were secured in a 96 well plate in which they were initially collected using a metal screen secured by several rubber bands. Once secured, samples were submerged in a solution of $10 \%$ bleach solution for approximately 14 minutes. After 14 minutes, plates were removed from the solution and any remaining solution in the wells were drained before being plated on glucose yeast extract agar with antibiotics (GYEA) and allowed to grow for one week. Each GYEA plate received a total of four bark plugs from the same tree, resulting in two plates for asymptomatic plugs and two additional plates for symptomatic plugs, when sampled. Plates were inspected daily for fungal growth and transferred to a new plate of GYEA as needed. Fungal isolates growing from the plugs were identified based on morphology, and a subset of each morphotype per site was stored on filter paper in the freezer. These retained morphotypes included isolates of genera such as Penicillium, Trichoderma and Pestalotiopsis. All Diplodia growing from the plugs were sub-cultured and retained as pure cultures. After seven days, any plugs that did not have fungal colonization were counted and classified as "uncolonized". If the percentage of these uncolonized plugs exceeded $40 \%$ of the total plugs, plates were maintained for an additional week and previously uncolonized plugs were reassessed as described above.

\section{$\underline{\text { Isolate Identification and Phylogenetic Analysis }}$}

Diplodia isolates were transferred from stock culture to a GYE agar plate that had a surface layer of sterile cellophane and grew for approximately one week before being used for DNA extraction. After this time, mycelium was scraped from the cellophane into a $1.5 \mathrm{~mL}$ microcentrifuge tubes (Eppendorf, Hamburg, Germany). Sealed tubes were flash frozen for five 
seconds in liquid nitrogen, after which frozen samples were macerated. After maceration, $600 \mu 1$ of Nuclei Lysis Solution (Promega, Madison, WI, USA) was added to each tube and incubated at $65{ }^{\circ} \mathrm{C}$ in at water bath for one-hour, vortexing for 10 seconds after 30 minutes. After one hour, samples were removed from the water bath and allowed to cool at room temperature for five minutes. Cooled samples then received $200 \mu 1$ of Protein Precipitation Solution (Promega, Madison, WI, USA) and were again vortexed for 10 seconds. After, samples were centrifuged for three minutes at 14,000 RMP and the supernatant was removed and transferred into a new sterile $1.5 \mathrm{~mL}$ centrifuge tube containing $600 \mu \mathrm{l}$ of isopropanol. The original tube and pellet were discarded. These newly transferred tubes were gently mixed by pipetting and then was centrifuged for three minutes at 14,000 RPM. The resulting centrifuge tube contained a supernatant which was discarded and a pellet that was retained. Tubes containing pellets received $600 \mu \mathrm{l}$ of $70 \%$ ethanol and were gently inverted before being centrifuged for two minutes at 14,000 RPM. The resulting supernatant was again discarded, and the pellet was retained. Tubes containing pellets were open and inverted for 15 minutes to dry at room temperature. The remaining pellet was then resuspended in $100 \mu 1$ of $65^{\circ} \mathrm{C}$ Elution Buffer (Alfa Aesar, Ward Hill, MA, USA) and stored in a $-20{ }^{\circ} \mathrm{C}$ freezer until PCR.

All collected Diplodia isolates were PCR amplified for the internal transcribed spacer region (ITS) using primers ITS4 and ITS5, the elongation factor gene (EF-1 $\alpha)$ using primers ef11782 and ef1-1567 and the large subunit (LSU) using primers LR5-LROR. To amplify these products, $10 \mu \mathrm{l}$ of molecular-grade water (G-Biosciences, St. Louis, MO, USA), $12.5 \mu$ l of Master Mix (Bioline, London, UK), $1 \mu \mathrm{l}$ of each respective forward and reverse primer (IDT, Coralville, IA, USA), and $1.5 \mu \mathrm{l}$ of template DNA were combined. 
ITS and EF-1 $\alpha$ gene regions were amplified using a three stage PCR reaction: an initial melting stage at $95{ }^{\circ} \mathrm{C}$ for two minutes, followed by 35 cycles of $95{ }^{\circ} \mathrm{C}$ for 30 seconds, $56{ }^{\circ} \mathrm{C}$ for 30 seconds, $72{ }^{\circ} \mathrm{C}$ for 60 seconds, and lastly a final extension at $72{ }^{\circ} \mathrm{C}$ for seven minutes. LSU gene region amplification was as follows: an initial melting at $95{ }^{\circ} \mathrm{C}$ for two minutes; 35 cycles of $95{ }^{\circ} \mathrm{C}$ for 30 seconds, $51.1^{\circ} \mathrm{C}$ for 45 seconds, and $72{ }^{\circ} \mathrm{C}$ for 90 seconds; and lastly, a final extension at $72{ }^{\circ} \mathrm{C}$ for five minutes.

After PCR, $10 \mu \mathrm{l}$ of PCR product were added to $4 \mu \mathrm{l}$ of SYBER Gold (Invitrogen, Grand Island, NY, USA) and $4 \mu \mathrm{l}$ of gel loading dye blue 6X (New England BioLabs Inc., MA, USA) before being pipetted into a $1.5 \%$ w/v agarose (Amresco, Solon, OH, USA) gel with $0.5 \%$ TrisBorate-EDTA buffer (Amresco, Solon, OH, USA). Using electrophoresis, resulting bands were analyzed on a UV transilluminator (Bio-Rad, Hercules, CA, USA) to visually confirm DNA amplification and quality. After analysis, PCR products that were deemed to be of good quality, were purified using ExoSAP-IT (Affymetrix, Santa Clara, CA, USA) in a reaction which consisted of a mixture of $6 \mu 1$ of PCR product, $2.2 \mu 1$ of ExoSAP and $2 \mu 1$ of molecular-grade water (G-Biosciences, St. Louis, MO). After purification, products were Sanger-sequenced (Eurofins, Louisville, KY, USA) using the same primers that were utilized for the respective PCR.

Chromatograms were clipped in CodonCode Aligner v. 5.1 .5 followed by manual screening for missing or miscalled nucleotides. DNA sequences were used as queries in BLASTN searches of the Genbank database. Once IDs were confirmed as either Diplodia or a member of the Botryosphaeriaceae, these isolates were moved forward for additional sequencing (EF-1 $\alpha$ and LSU) and subjected to phylogenetic analysis. Each of the three analyzed gene regions were separately aligned using MEGA v. 7.0.16 (Kumar et al. 2016) and then combined 
into a single aligned gene using FaBox (Villesen 2007). For maximum likelihood analyses, a best fitting model was chosen using Model Selection analysis and 1,000 bootstrap replicates were used with the best tree being identified and bootstrapped in a single run. In the final selected tree, strong boot-strap support was observed and documented if boot-strap values met or exceeded $70 \%$ and marginal support if boot-strap values were between $50 \%$ and $69 \%$. Boot-strap values that were less than $50 \%$ are considered weak support and were not included in the analysis.

\section{Inhibition Assays}

Due to low incidence of recovery of Diplodia spp. from collected bark tissues, we sought to assess inhibition of Diplodia by other fungi recovered regularly from bark tissues across all forests. These environmental fungi, classified as such for their common occurrence across numerous natural and built environments, included Penicillium spp., Trichoderma spp., and Pestalotiopsis spp. Fungal pairings included two randomly chosen isolates for each of the three dominant environmental fungi and were paired against six randomly selected Diplodia spp. This initial pairing preceded species-level identifications using ITS barcoding, so three Diplodia spp. were randomly chosen from being isolated from white oak family members and three Diplodia spp. were randomly chosen from being isolated form red oak family members. ITS barcoding subsequently identified the selected isolates as five $D c$ isolates and one $D q$ isolate. Each pairing consisted of two $0.5 \mathrm{~cm}$ diameter GYEA plugs, one fully colonized by Diplodia, the other fully colonized by the competing fungus. Each competing set of fungal plugs were plated on opposite sides of the petri dish containing GYEA and was repeated in duplicate. Each week, pairings were observed and after a month the experiment was terminated, and co-cultures were discarded. Based off the results of the first pairing assay, a second pairing assay was implemented using 
isolates that had either significantly inhibited Diplodia or that were significantly inhibited by Diplodia.

For the second pairing, two of the six Diplodia isolates were retained from the original pairing, one sequence confirmed $D c$ and one sequence confirmed $D q$, along with a previously used Penicillium, Trichoderma and Pestalotiopsis. In addition to these isolates, four new Diplodia isolates were selected randomly by species post ITS identification so that each recovered species was represented. The newly selected Diplodia isolates were randomly selected from each of three species: $D c, D q, D$. sapinea $(D s)$, and Botryosphaeria dothidea $(B d)$. In addition to the three retained environmental fungi from the original pairing, two newly selected Penicillium, Trichoderma and Pestalotiopsis were randomly selected and included in the assay.

Spore Production and Associated Measurements

All retained Diplodia isolates were plated on $1 / 10^{\text {th }}$ strength GYE agar using a $0.5 \mathrm{~cm}$ diameter plug and left under continuous light to induce sporulation (Ferreira Chapter 2 2019). Isolates were observed weekly for pycnidia and spore production, and after one-month, morphological observations including presence of pycnidia and spore measurements were made. Spores were mounted on slides containing lactophenol to observe spore size and morphology. The length and width of twenty-five randomly selected spores were measured at the longest point using a Nikon Eclipse E600 microscope and NIS-Elements BR 3.2 under 40X magnification. Spore sizes and associated features (i.e. number of septations and spore pigmentation) were compared between species and among geographic location using analysis of variance (ANOVA) and then between locations using Tukey Kramer's post HOC test. 


\section{Colony Morphology using Specialized Media}

All recovered Diplodia isolates were plated from the $1 / 10^{\text {th }}$ GYE media to pine needle extract (PNE) agar (Ferreira Chapter 2 2019) using a fully colonized $0.5 \mathrm{~cm}$ diameter plug and allowed to grow for two weeks. After two weeks, morphology of isolates was observed between species and geographic location.

\section{Results:}

A total of 5,335 bark plugs were processed from 563 oak trees spanning 33 individual forests across the four sampled states. These efforts resulted in the recovery of 32 isolates of Diplodia spp. from 13 out of the 18 (72\%) sampled counties (Figure 5). Six hundred eighty-eight total plugs were uncolonized by fungi $(\sim 13 \%)$, with a $<1 \%$ recovery rate of Diplodia spp. from colonized plugs. 


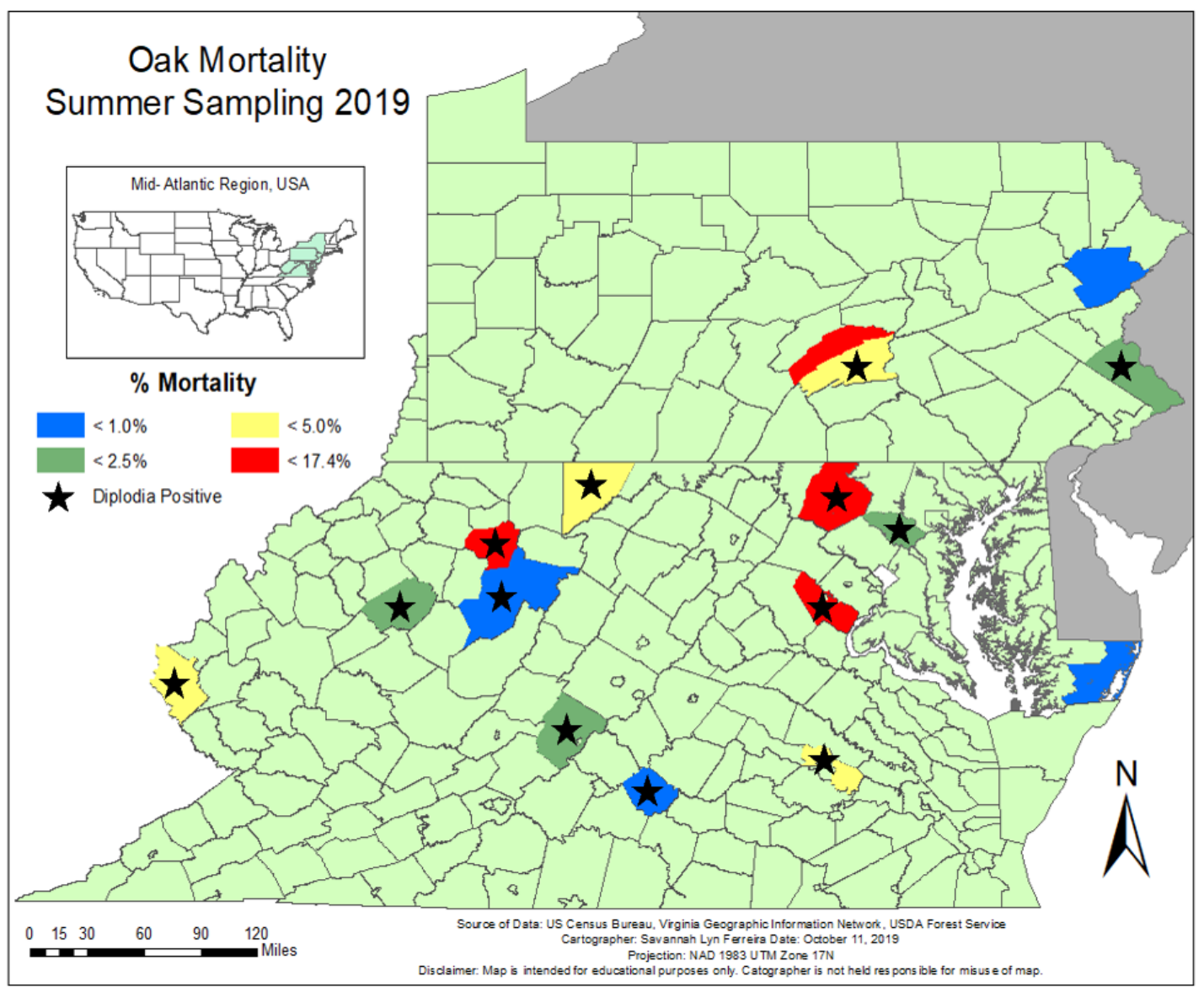

Figure 5: Oak Mortlity Summer Sampling 2019 Map showing Diplodia positive counties ( $\mathrm{n}=$ $13)$.

ITS barcoding confirmed identities of the 32 isolates of Diplodia spp.: 21 most closely matched with $D c$, six with $D q$, three with $D s$, and two with $B d$. In $\mathrm{MD}$, both $D c$ and $D q$ were recovered from a total of four total forests. In PA, $D c$ and $D s$ were recovered from a total of four forests. In VA, $D c$ was recovered from four forests. In WV, $D c, D q, D s$ and $B d$ were recovered from a total six forests. For details of specific locations and isolates recovered see Table 2. 
Table 2: Forests and location of recovered Diplodia spp.

\begin{tabular}{|c|c|c|c|c|c|}
\hline State & County & $\begin{array}{c}\text { FIA } \\
\text { Mortality }\end{array}$ & Forests Sampled & Diplodia Spp. & $\begin{array}{c}\text { Count of } \\
\text { Recovered } \\
\text { Isolates }\end{array}$ \\
\hline MD & Worcester & $<1 \%$ & Pocomoke State Forest & NA & 0 \\
\hline \multirow{2}{*}{ MD } & \multirow{2}{*}{ Howard } & \multirow{2}{*}{$<2.5 \%$} & Patapsco Valley State Park & NA & 0 \\
\hline & & & Middle Patuxent Environmental Area & $D q$ & 3 \\
\hline \multirow{2}{*}{ MD } & \multirow{2}{*}{ Garrett } & \multirow{2}{*}{$<5 \%$} & Garrett State Forest & $D c$ & 2 \\
\hline & & & Deep Creek Lake State Park & $D c$ & 2 \\
\hline \multirow{2}{*}{ MD } & \multirow{2}{*}{ Fredrick } & \multirow{2}{*}{$<17.4 \%$} & Gambrill State Park & $D q$ & 1 \\
\hline & & & South Mountain State Park & NA & 0 \\
\hline \multirow{2}{*}{ PA } & \multirow{2}{*}{ Monroe } & \multirow{2}{*}{$<1 \%$} & Big Pocono State Park & NA & 0 \\
\hline & & & State Game Lands \#38 & NA & 0 \\
\hline \multirow{2}{*}{ PA } & \multirow{2}{*}{ Bucks } & \multirow{2}{*}{$<2.5 \%$} & Tyler State Park & $D c, D s$ & 2 \\
\hline & & & Nockamixon State Park & $D c$ & 6 \\
\hline \multirow{2}{*}{ PA } & \multirow{2}{*}{ Perry } & \multirow{2}{*}{$<5 \%$} & Tuscarora State Forest & $D c$ & 1 \\
\hline & & & Little Buffalo State Park & Ds & 1 \\
\hline \multirow{2}{*}{ PA } & \multirow{2}{*}{ Juniata } & \multirow{2}{*}{$<17.4 \%$} & State Game Land \#215 & NA & 0 \\
\hline & & & Small area of Tuscarora State Forest & NA & 0 \\
\hline \multirow{2}{*}{ VA } & \multirow{2}{*}{ Appomattox } & \multirow{2}{*}{$<1 \%$} & Appomattox-Buckingham State Forest & $D c$ & 1 \\
\hline & & & Featherfin Wildlife Management Area & NA & 0 \\
\hline \multirow{2}{*}{ VA } & \multirow{2}{*}{ Rockbridge } & \multirow{2}{*}{$<2.5 \%$} & Glenn Maury Park & $D c$ & 2 \\
\hline & & & Goshen Wildlife Management Area & NA & 0 \\
\hline \multirow{2}{*}{ VA } & \multirow{2}{*}{ Henrico } & \multirow{2}{*}{$<5 \%$} & Four Mile Creek Park & $D c$ & 1 \\
\hline & & & Deep Bottom Park & $N A$ & 0 \\
\hline so & Drinolllom & 1700 & Merrimac Farm Wildlife Management Area & NA & 0 \\
\hline$V A$ & Promice vomitim & $17.4 \%$ & Conway Robinson State Forest & $D c$ & 2 \\
\hline in & 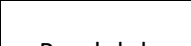 & 10 & Monongahela National Forest & NA & 0 \\
\hline & & & Kumbrabow State Forest & $D c$ & 1 \\
\hline whe & Drastost & -250 & Burnsville Lake Wildlife Management Area & Ds & 1 \\
\hline & & & Elk River Wildlife Management Area & $D q$ & 1 \\
\hline Wu & Whymp & -50 & East Lynn Wildlife Management Area & $D q$ & 1 \\
\hline & & & Beech Fork Lake Wildlife Management Area & $B d$ & 2 \\
\hline ist & B & 70 & Teter Creek Lake Wildlife Management Area & NA & 0 \\
\hline & & & Audra State Park & $D c$ & 2 \\
\hline
\end{tabular}




\section{Field Sampling}

Five hundred sixty-three oak trees were sampled between red $(n=191)$ and white oak $(n$ =372) family members in 33 forests in the Mid-Atlantic region, 507 of which were sampled for fungal colonization. The remaining 56 trees were excluded from fungal sampling due to number of trees in each forest exceeding the allowable sample size based on the landowner's permits. The red oak family members observed included red oak $(\mathrm{n}=146)$, pin oak $(Q$. palustris $)(\mathrm{n}=16)$ and turkey oak $(Q$. laevis $)(\mathrm{n}=29)$, while white oak family members included white oak $(Q$. alba) $(\mathrm{n}=194)$, chestnut oak $(Q \cdot$ montana $)(\mathrm{n}=167)$, southern white oak $(Q$. bicolor $)(\mathrm{n}=10)$ and willow oak $(Q \cdot$ phellos $)(\mathrm{n}=1)($ Figure 6).

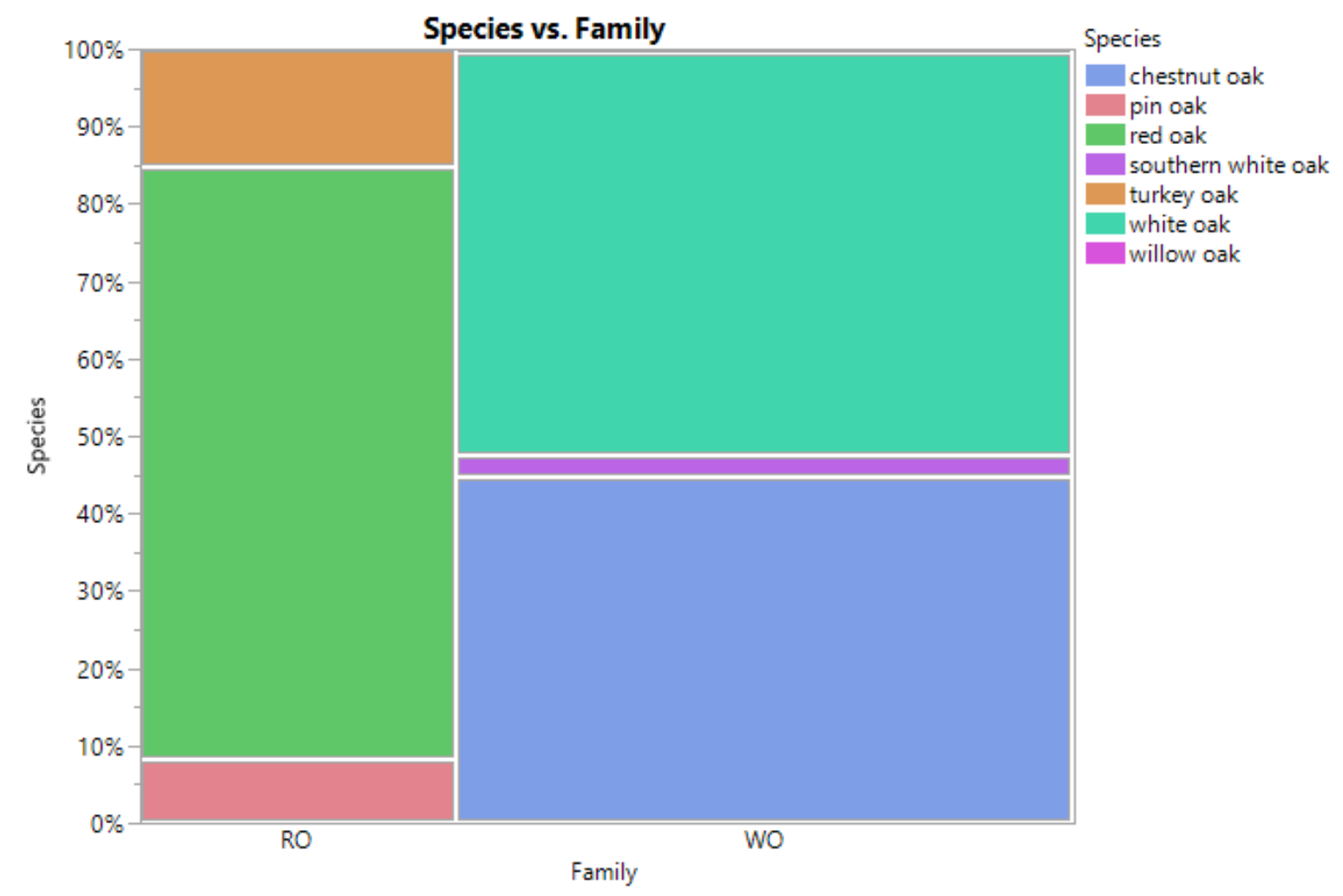

Figure 6: Mosaic plot comparing incidence of red oak family members $(n=191)$ to white oak family members $(n=372)$ observed during this study. 
$\underline{\text { Dieback }}$

Dieback for all oak trees that fell within the 10 basal area factor variable radius plot were evaluated and recorded. This included 191 ratings for red oak family members and 372 ratings for white oak family members. Observations were grouped into 5 discrete categories, 1: 0-24\% dieback, 2: 25-49\% dieback, 3: 50-74\% dieback, 4: 75-99\% dieback and 5: 100\% dieback (dead).

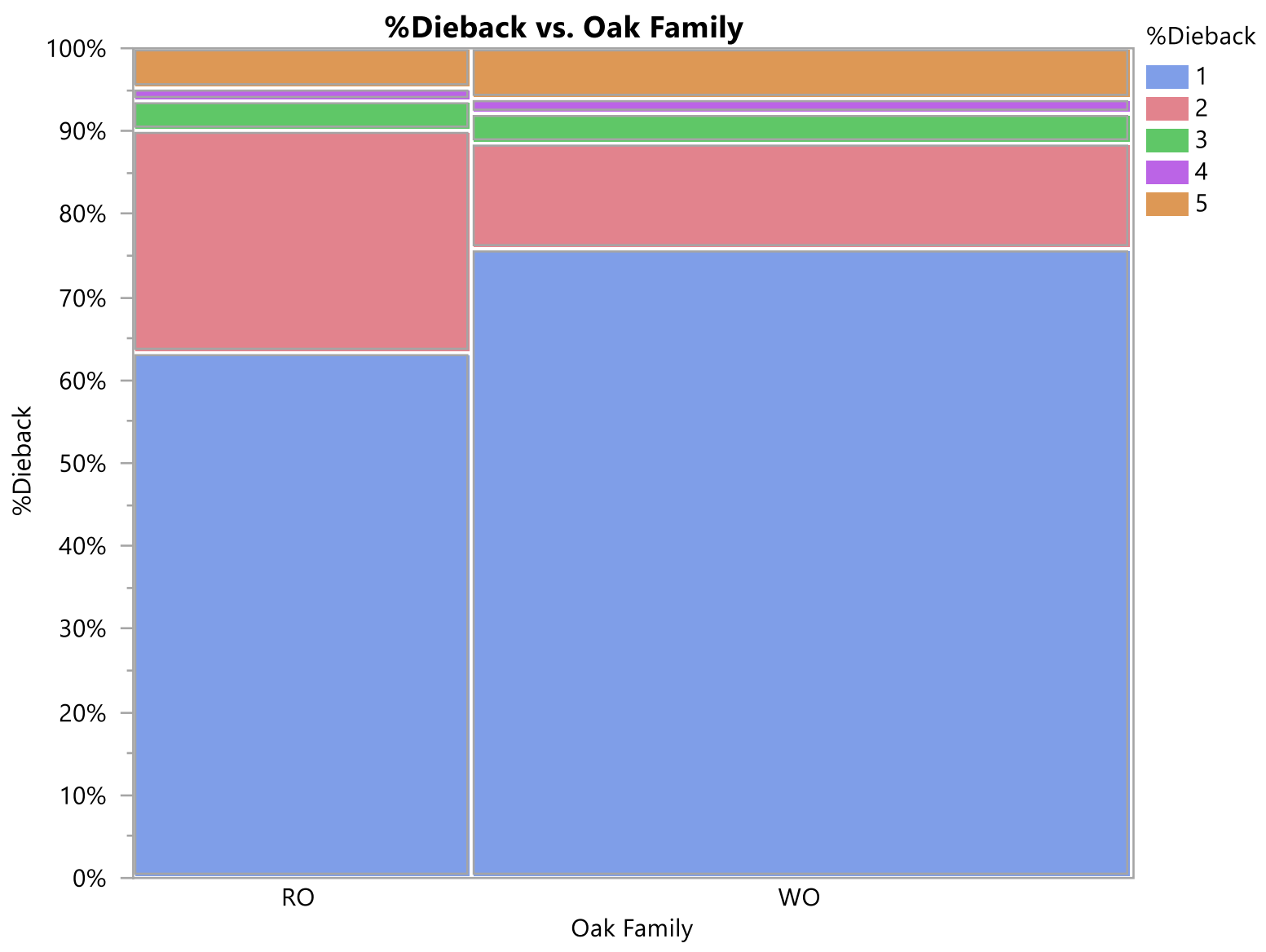

Figure 7: Mosaic plot comparing red oak family dieback to white oak family dieback. Data are separated by \%dieback $(1: 0-24 \%$ dieback $(n=403)), 2: 25-49 \%$ dieback $(n=99), 3: 50-74 \%$ dieback $(n=20), 4: 75-99 \%$ dieback $(n=10)$ and 5: $100 \%$ dieback $($ dead $)(n=31)$ and oak family $(\mathrm{RO}=$ red oak family members $(\mathrm{n}=191), \mathrm{WO}=$ white oak family members $(\mathrm{n}=372)$ ). 
Table 3: Summary statistics for dieback rating by family for all oberved oak trees. Data are separated by \%dieback $(1: 0-24 \%$ dieback $(\mathrm{n}=403)), 2: 25-49 \%$ dieback $(\mathrm{n}=99), 3: 50-74 \%$ dieback $(\mathrm{n}=20), 4: 75-99 \%$ dieback $(\mathrm{n}=10)$ and $5: 100 \%$ dieback $(\mathrm{dead})(\mathrm{n}=31))$ and oak family $(\mathrm{RO}=$ red oak family members $(\mathrm{n}=191), \mathrm{WO}=$ white oak family members $(\mathrm{n}=372))$.

\begin{tabular}{|c|c|c|c|c|c|c|}
\hline \multicolumn{7}{|c|}{$\%$ Dieback } \\
\hline \begin{tabular}{|l} 
Count \\
Total \% \\
Col \% \\
Row $\%$
\end{tabular} & & 2 & 3 & & 5 & Total \\
\hline$\geqslant R O$ & 121 & 51 & 7 & 3 & 9 & 191 \\
\hline & 21.49 & 9.06 & 1.24 & 0.53 & 1.60 & 33.93 \\
\hline & 30.02 & 51.52 & 35.00 & 30.00 & 29.03 & \\
\hline & 63.35 & 26.70 & 3.66 & 1.57 & 4.71 & \\
\hline WO & 282 & 48 & 13 & 7 & 22 & 372 \\
\hline & 50.09 & 8.53 & 2.31 & 1.24 & 3.91 & 66.07 \\
\hline & 69.98 & 48.48 & 65.00 & 70.00 & 70.97 & \\
\hline & 75.81 & 12.90 & 3.49 & 1.88 & 5.91 & \\
\hline Total & 403 & 99 & 20 & 10 & 31 & 563 \\
\hline & 71.58 & 17.58 & 3.55 & 1.78 & 5.51 & \\
\hline
\end{tabular}

Oak family was a significant predictor of percent dieback (chi-square $=16.10, \mathrm{p}$-value $=$ 0.0029), with white oak family members having higher counts for more severe dieback ratings than red oak family members (Figure 7). Four hundred and three of the total observed trees had a dieback rating of 1 , with 282 being white oak family members and 121 were red oak family members (Figure 8). The remaining 160 total red and white oak trees measured had dieback ratings of $2-5$, with the majority (17.58\%) with a rating of 2 . This included 48 trees belonging to white oak family members and 51 trees belonging to red oak family members. Twenty total trees (3.55\%) were observed to be in dieback category 3 and consisted of 13 white oak family members and seven red oak family members. The least represented category was for trees with a dieback rating 4 , which was only comprised of 10 trees (1.78\%); seven from white oak family members and three from red oak family members. Thirty-one trees (5.51\%) were standing dead 
with a dieback rating of $100 \%$. This included 22 trees belonging to white oak family members and nine trees belonging to red oak family members (Table 3).

Tree branch dieback is a normal process that occurs as trees mature and are recruited into higher canopy classes but can also be a predictor of biotic stressors (Bostock et al. 2014, Schomaker et al. 2007). In this study, canopy position was a significant predictor of percent dieback (chi-square 117.95, p-value <0.0001).

Most observed canopy classes had category 1 dieback $(n=403)$ followed by a category 2 dieback $(n=99)$ (Table 4). Dominant trees had the most dieback by canopy class, followed by intermediate and understory trees (Figure 8). Out of the 563 observed oak trees, 79 had a dominant canopy class, with $36.71 \%$ of trees having dieback exceeding category 1 dieback. Three hundred and seventy-three total trees were positioned in a co-dominant canopy class with $23.06 \%$ of trees having a dieback rating of 2 or higher. Intermediate trees had 72 observations with $30.56 \%$ of trees having a dieback rating 2-5. Understory trees were the least frequent, with 23 observations and only $30.43 \%$ of trees exceeding dieback rating of 1 . Out of all observed oak trees, 16 were too advanced in decay to determine where their position in the canopy would reside (Table 4). 


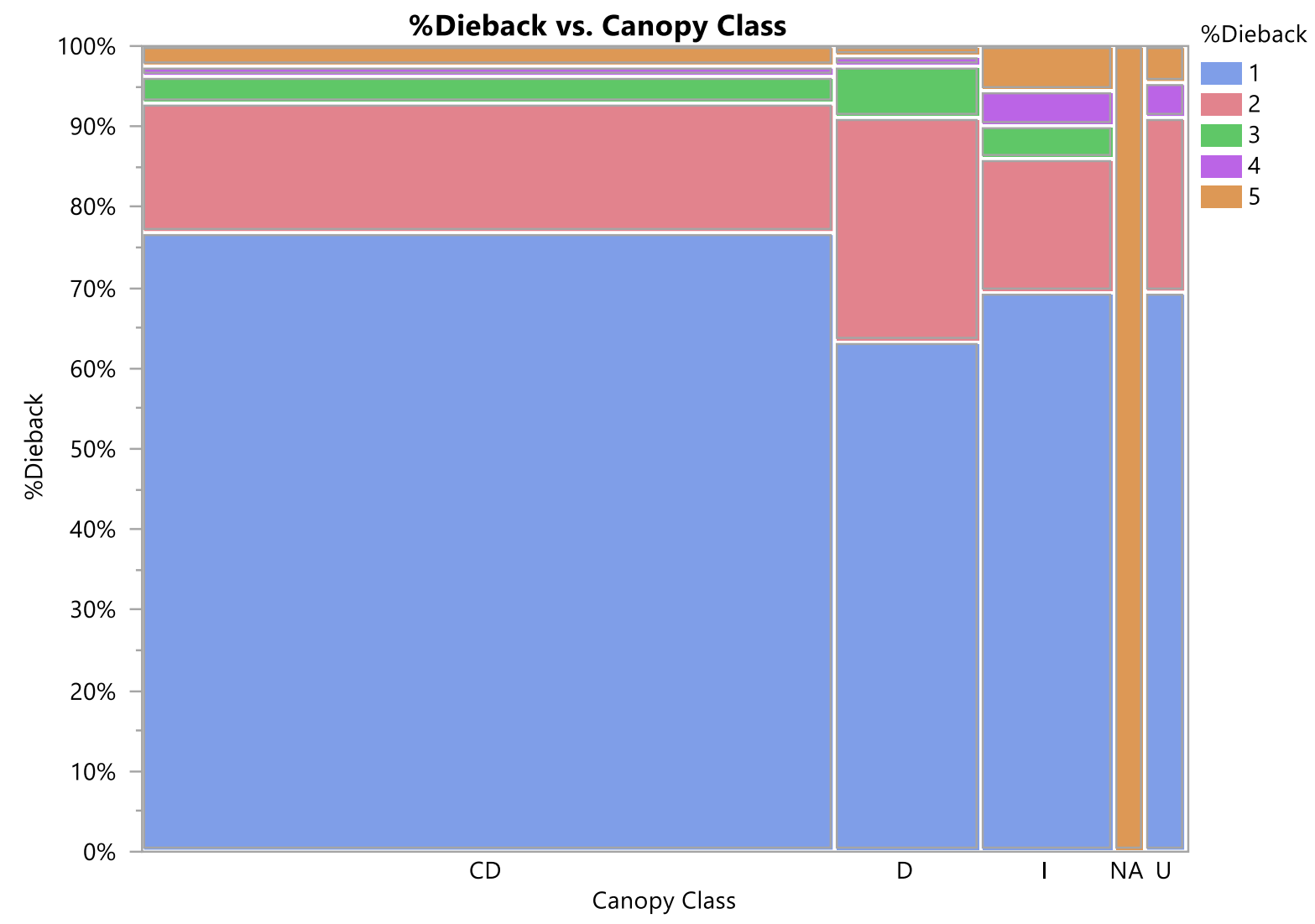

Figure 8: Mosaic plot showing \%dieback vs. canopy class. Data are separated by \%dieback (1: 0$24 \%$ dieback $(n=403)), 2: 25-49 \%$ dieback $(n=99), 3: 50-74 \%$ dieback $(n=20), 4: 75-99 \%$ dieback $(\mathrm{n}=10)$ and $5: 100 \%$ dieback $($ dead $)(\mathrm{n}=31))$ and canopy class $(\mathrm{CD}=$ codominant $(\mathrm{n}=$ 373), $\mathrm{D}=$ dominant $(\mathrm{n}=79), \mathrm{I}=$ intermediate $(\mathrm{n}=72), \mathrm{NA}=$ not applicable because it is so dead $(\mathrm{n}=16), \mathrm{U}=$ understory $(\mathrm{n}=23))$. 
Table 4: Summary statistics for dieback rating by canopy class for all oberved oak trees. Data are separated by \%dieback $(1: 0-24 \%$ dieback $(n=403)), 2: 25-49 \%$ dieback $(n=99), 3: 50-74 \%$ dieback $(n=20), 4: 75-99 \%$ dieback $(n=10)$ and 5: $100 \%$ dieback $($ dead $)(n=31))$ and canopy class $(C D=$ codominant $(n=373), D=$ dominant $(n=79), I=$ intermediate $(n=72), N A=$ not applicable because it is so dead $(n=16), U=$ understory $(n=23))$.

\begin{tabular}{|c|c|c|c|c|c|c|}
\hline \multicolumn{7}{|c|}{ \%Dieback } \\
\hline $\begin{array}{l}\text { Count } \\
\text { Total } \% \\
\text { Col } \% \\
\text { Row } \%\end{array}$ & 1 & 2 & 3 & 4 & 5 & Total \\
\hline \multirow[t]{4}{*}{$C D$} & 287 & 60 & 12 & 5 & 9 & 373 \\
\hline & 50.98 & 10.66 & 2.13 & 0.89 & 1.60 & 66.25 \\
\hline & 71.22 & 60.61 & 60.00 & 50.00 & 29.03 & \\
\hline & 76.94 & 16.09 & 3.22 & 1.34 & 2.41 & \\
\hline \multirow[t]{8}{*}{ D } & 50 & 22 & 5 & 1 & 1 & 79 \\
\hline & 8.88 & 3.91 & 0.89 & 0.18 & 0.18 & 14.03 \\
\hline & 12.41 & 22.22 & 25.00 & 10.00 & 3.23 & \\
\hline & 63.29 & 27.85 & 6.33 & 1.27 & 1.27 & \\
\hline & 50 & 12 & 3 & 3 & 4 & 72 \\
\hline & 8.88 & 2.13 & 0.53 & 0.53 & 0.71 & 12.79 \\
\hline & 12.41 & 12.12 & 15.00 & 30.00 & 12.90 & \\
\hline & 69,44 & 16.67 & 4.17 & 4.17 & 5.56 & \\
\hline \multirow[t]{4}{*}{ NA } & 0 & 0 & 0 & 0 & 16 & 16 \\
\hline & 0.00 & 0.00 & 0.00 & 0.00 & 2.84 & 2.84 \\
\hline & 0.00 & 0.00 & 0.00 & 0.00 & 51.61 & \\
\hline & 0.00 & 0.00 & 0.00 & 0.00 & 100.00 & \\
\hline \multirow[t]{4}{*}{ U } & 16 & 5 & 0 & 1 & 1 & 23 \\
\hline & 2.84 & 0.89 & 0.00 & 0.18 & 0.18 & 4.09 \\
\hline & 3.97 & 5.05 & 0.00 & 10.00 & 3.23 & \\
\hline & 69.57 & 21.74 & 0.00 & 4.35 & 4.35 & \\
\hline \multirow[t]{2}{*}{ Total } & 403 & 99 & 20 & 10 & 31 & 563 \\
\hline & 71.58 & 17.58 & 3.55 & 1.78 & 5.51 & \\
\hline
\end{tabular}

\section{$\underline{\text { Outward Symptoms }}$}

Outward symptoms including sooty lesions and dieback have been reported being associated with Diplodia (Aćimović et al. 2016, Martin et al. 2017, Dreaden et a. 2011) and in this study, served as a significant predictor of dieback (chi-square $=91.78$, p-value $<0.0001$ ).

Excluding dieback as an outward symptom, 160 observed trees had at least one discrete symptom while 403 were outwardly asymptomatic. An additional 12 trees were dead and in an 
advanced state of decay and therefore bole symptoms could not be assessed (Table 5). For symptomatic trees, the majority of observations across all symptom classes had a dieback rating of 1 , following by a dieback rating of 2 for symptom classes 1-3 (Figure 9). A majority of trees in symptom class 4 , excluding dieback category 1 , had a dieback rating of 5 (Table 5).

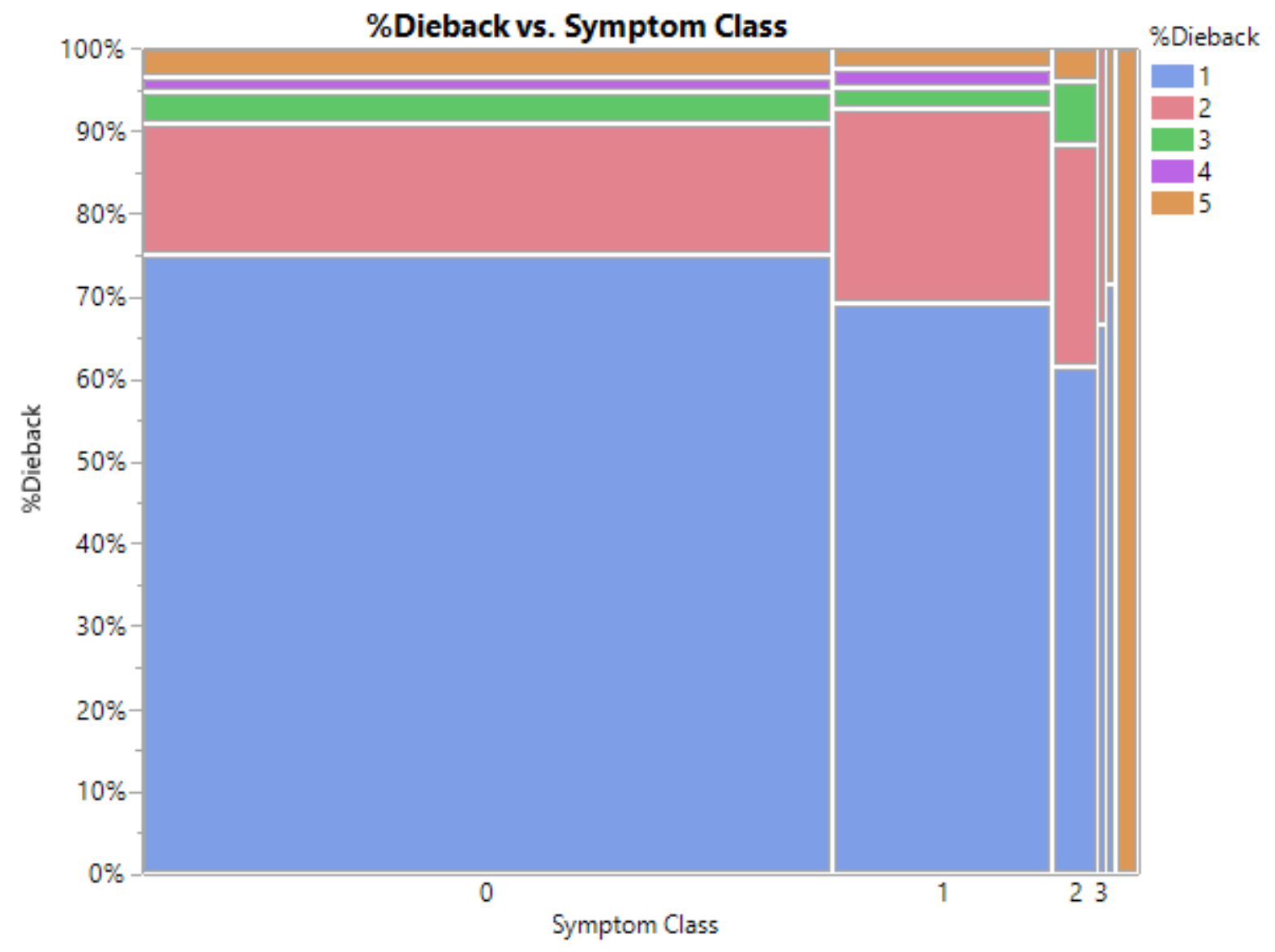

Figure 9: Mosaic plot showing \%dieback vs. symptom class. Data are separated by \%dieback (1: 0-24\% dieback $(\mathrm{n}=403)), 2: 25-49 \%$ dieback $(\mathrm{n}=99), 3: 50-74 \%$ dieback $(\mathrm{n}=20), 4: 75-99 \%$ dieback $(\mathrm{n}=10)$ and 5: $100 \%$ dieback $($ dead $)(\mathrm{n}=31))$ and symptom class $(0=$ no outward symptoms $(n=391), 1=1-3$ visible cankers $(n=124), 2=4-6$ visible cankers $(n=26), 3=7-9$ visible cankers $(n=3), 4=$ more than 9 visible cankers $(n=7), N A=$ not applicable because it is so dead $(n=12))$.

Table 5: Summary statistics for dieback rating by symptom class for all observed oak trees. Data are separated by \%dieback $(1: 0-24 \%$ dieback $(\mathrm{n}=403)), 2: 25-49 \%$ dieback $(\mathrm{n}=99), 3: 50-74 \%$ dieback $(n=20), 4: 75-99 \%$ dieback $(n=10)$ and 5: 100\% dieback $($ dead $)(n=31))$ and 
symptom class $(0=$ no outward symptoms $(n=391), 1=1-3$ visible cankers $(n=124), 2=4-6$ visible cankers $(n=26), 3=7-9$ visible cankers $(n=3), 4=$ more than 9 visible cankers $(n=7)$, $\mathrm{NA}=$ not applicable because it is so dead $(\mathrm{n}=12))$.

\begin{tabular}{|c|c|c|c|c|c|c|}
\hline \multicolumn{7}{|c|}{$\%$ Dieback } \\
\hline \begin{tabular}{|l|} 
Count \\
Total \% \\
Col \% \\
Row \% \\
\end{tabular} & 1 & 2 & 3 & 4 & 5 & Total \\
\hline \multirow[t]{4}{*}{0} & 294 & 62 & 15 & 7 & 13 & 391 \\
\hline & 52.22 & 11.01 & 2.66 & 1.24 & 2.31 & 69,45 \\
\hline & 72.95 & 62.63 & 75.00 & 70.00 & 41.94 & \\
\hline & 75.19 & 15.86 & 3.84 & 1.79 & 3.32 & \\
\hline \multirow[t]{4}{*}{1} & 86 & 29 & 3 & 3 & 3 & 124 \\
\hline & 15.28 & 5.15 & 0.53 & 0.53 & 0.53 & 22.02 \\
\hline & 21.34 & 29.29 & 15.00 & 30.00 & 9.68 & \\
\hline & 69.35 & 23.39 & 2.42 & 2.42 & 2.42 & \\
\hline & 16 & 7 & 2 & 0 & 1 & 26 \\
\hline & 2.84 & 1.24 & 0.36 & 0.00 & 0.18 & 4.62 \\
\hline & 3.97 & 7.07 & 10.00 & 0.00 & 3.23 & \\
\hline & 61.54 & 26.92 & 7.69 & 0.00 & 3.85 & \\
\hline \multirow[t]{4}{*}{3} & 2 & 1 & 0 & 0 & 0 & 3 \\
\hline & 0.36 & 0.18 & 0.00 & 0.00 & 0.00 & 0.53 \\
\hline & 0.50 & 1.01 & 0.00 & 0.00 & 0.00 & \\
\hline & 66.67 & 33.33 & 0.00 & 0.00 & 0.00 & \\
\hline \multirow[t]{4}{*}{4} & 5 & 0 & 0 & 0 & 2 & 7 \\
\hline & 0.89 & 0.00 & 0.00 & 0.00 & 0.36 & 1.24 \\
\hline & 1.24 & 0.00 & 0.00 & 0.00 & 6.45 & \\
\hline & 71,43 & 0.00 & 0.00 & 0.00 & 28.57 & \\
\hline \multirow[t]{4}{*}{ NA } & 0 & 0 & 0 & 0 & 12 & 12 \\
\hline & 0.00 & 0.00 & 0.00 & 0.00 & 2.13 & 2.13 \\
\hline & 0.00 & 0.00 & 0.00 & 0.00 & 38.71 & \\
\hline & 0.00 & 0.00 & 0.00 & 0.00 & 100.00 & \\
\hline \multirow[t]{2}{*}{ Total } & 403 & 99 & 20 & 10 & 31 & 563 \\
\hline & 71.58 & 17.58 & 3.55 & 1.78 & 5.51 & \\
\hline
\end{tabular}

Family was also a significant predictor of symptom class (chi-square 31.72, p-value < 0.0001) with white oak family members being less likely to show conspicuous and discrete symptoms including cankers and sooty lesions than red oak family members. 


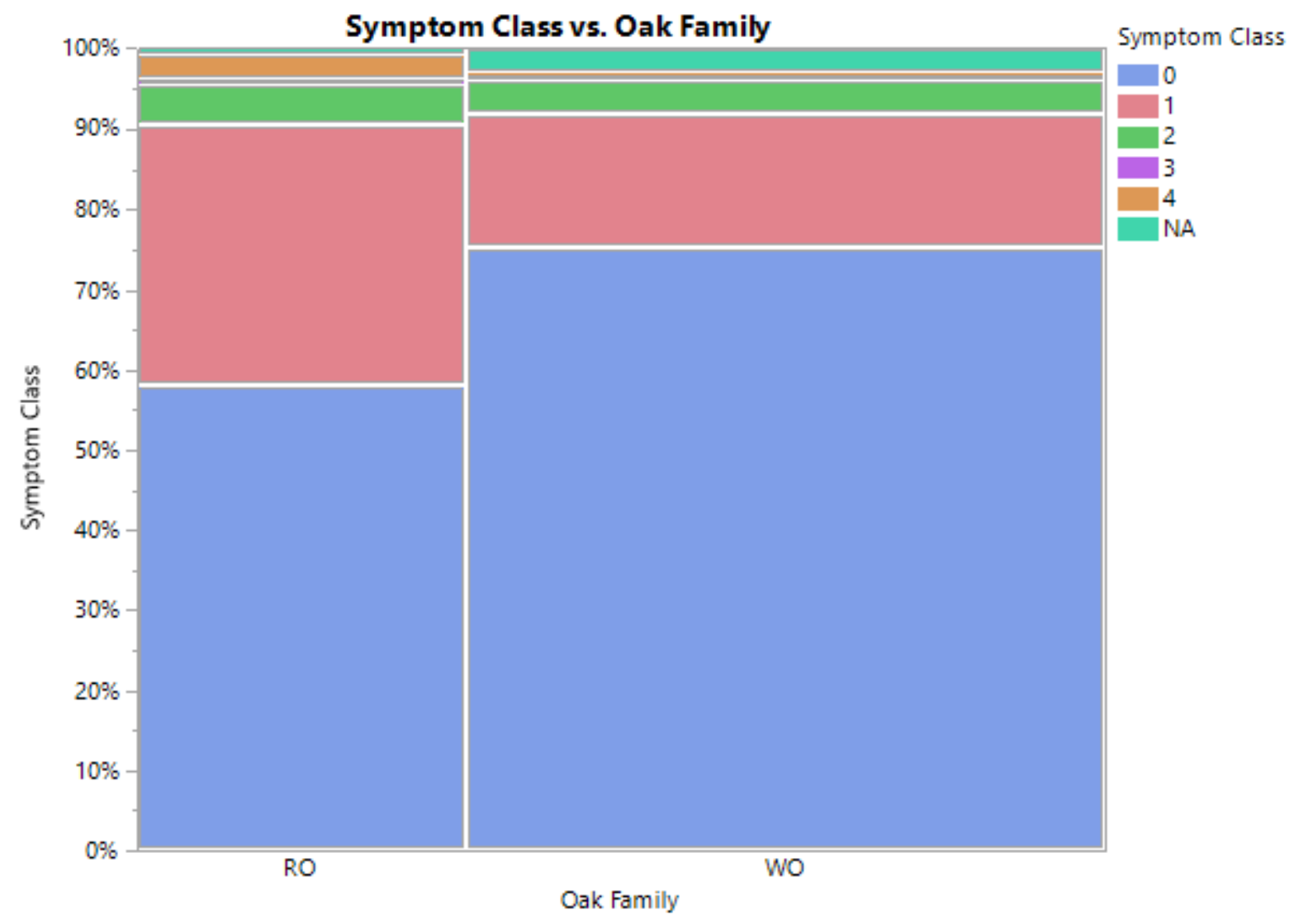

Figure 10: Mosaic plot showing symptom class vs. oak family. Data are separated by symptom class $(0=$ no outward symptoms $(n=391), 1=1-3$ visible cankers $(n=124), 2=4-6$ visible cankers $(n=26), 3=7-9$ visible cankers $(n=3), 4=$ more than 9 visible cankers $(n=7), N A=$ not applicable because it is so dead $(\mathrm{n}=12)$ and oak family $(\mathrm{RO}=$ red oak family members $(\mathrm{n}=$ $191), \mathrm{WO}=$ white oak family members $(\mathrm{n}=372)$ ). 
Table 6: Summary statistics for symptom class by oak family. Data are separated by symptom class $(0=$ no outward symptoms $(\mathrm{n}=391), 1=1-3$ visible cankers $(\mathrm{n}=124), 2=4-6$ visible cankers $(n=26), 3=7-9$ visible cankers $(n=3), 4=$ more than 9 visible cankers $(n=7), N A=$ not applicable because it is so dead $(\mathrm{n}=12)$ and oak family $(\mathrm{RO}=$ red oak family members $(\mathrm{n}=$ 191), $\mathrm{WO}=$ white oak family members $(\mathrm{n}=372))$.

\begin{tabular}{|c|c|c|c|c|c|c|c|}
\hline \multicolumn{8}{|c|}{ Symptom Class } \\
\hline \begin{tabular}{|l|} 
Count \\
Total \% \\
Col \% \\
Row \% \\
\end{tabular} & 0 & 1 & 2 & 3 & 4 & NA & Total \\
\hline \multirow{4}{*}{ 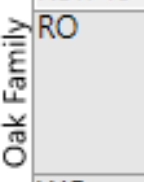 } & 111 & 62 & 10 & 1 & 6 & 1 & 191 \\
\hline & 19.72 & 11.01 & 1.78 & 0.18 & 1.07 & 0.18 & 33.93 \\
\hline & 28.39 & 50.00 & 38.46 & 33.33 & 85.71 & 8.33 & \\
\hline & 58.12 & 32.46 & 5.24 & 0.52 & 3.14 & 0.52 & \\
\hline \multirow[t]{4}{*}{ WO } & 280 & 62 & 16 & 2 & 1 & 11 & 372 \\
\hline & 49.73 & 11.01 & 2.84 & 0.36 & 0.18 & 1.95 & 66.07 \\
\hline & 71.61 & 50.00 & 61.54 & 66.67 & 14.29 & 91.67 & \\
\hline & 75.27 & 16.67 & 4.30 & 0.54 & 0.27 & 2.96 & \\
\hline \multirow[t]{2}{*}{ Total } & 391 & 124 & 26 & 3 & 7 & 12 & 563 \\
\hline & 69.45 & 22.02 & 4.62 & 0.53 & 1.24 & 2.13 & \\
\hline
\end{tabular}

The majority of oaks observed in this survey were white oak family members $(n=372)$ (Table 6). Although fewer in counts, $41.36 \%$ of observed red oak family members had at least one conspicuous and discrete symptom, compared to white oak family members that only had $21.77 \%$ (Figure 10, Table 6). Between both families, the majority of symptomatic trees fell into symptom class $1(\mathrm{n}=124)($ Table 6$)$.

\section{Diplodia presence}

Five hundred and seven trees were micro-sampled for Diplodia spp. presence, which included 347 trees without any conspicuous and discrete symptoms and 160 with conspicuous and discrete symptoms (Table 8). Thirty-two isolates of Diplodia were isolated and retained from 27 trees (Table 7). From these trees, 13 Diplodia isolates were recovered from symptomatic bole tissues and 19 from outwardly asymptomatic bole tissues. Four trees had multiple isolates in 
either symptomatic or asymptomatic tissue, so only 28 isolates of Diplodia were used in the analysis.

Table 7: Forests locations and host data for recovered Diplodia spp.

\begin{tabular}{|c|c|c|c|c|c|c|c|c|}
\hline State & Site & Isolate & Host & $\mathrm{CC}$ & Dieback & $\begin{array}{c}\text { Symptom } \\
\text { Class }\end{array}$ & Tissue & $\begin{array}{c}\text { Diplodia } \\
\text { Spp. }\end{array}$ \\
\hline MD & Deep Creek Lake State Park & DC2-3C & $\mathrm{RO}$ & $\mathrm{CD}$ & 1 & 4 & Symptomatic & $D c$ \\
\hline MD & Deep Creek Lake State Park & $\mathrm{DC} 2-3 \mathrm{H}$ & RO & $\mathrm{CD}$ & 1 & 4 & Symptomatic & $D c$ \\
\hline MD & Gambrill State Park & GM4-7D & $\mathrm{CO}$ & $\mathrm{CD}$ & 1 & 0 & Asymptomatic & $D q$ \\
\hline MD & Garrett State Forest & GT5-11E & RO & $\mathrm{D}$ & 2 & 2 & \begin{tabular}{|l|} 
Symptomatic \\
\end{tabular} & $D c$ \\
\hline MD & Garrett State Forest & GT5-3H & RO & $\mathrm{CD}$ & 2 & 0 & Asymptomatic & $D c$ \\
\hline MD & Patapsco Valley State Park & PR11-19H & $\mathrm{CO}$ & NA & 5 & 4 & Symptomatic & $D q$ \\
\hline MD & Patapsco Valley State Park & PR11-1A & $\mathrm{CO}$ & $\mathrm{CD}$ & 1 & 0 & Asymptomatic & $D q$ \\
\hline MD & Patapsco Valley State Park & PR11-5F & $\mathrm{CO}$ & $\mathrm{CD}$ & 1 & 0 & Asymptomatic & $D q$ \\
\hline $\mathrm{PA}$ & Little Buffalo State Park & LB5-4B & $\mathrm{CO}$ & $\mathrm{CD}$ & 1 & 0 & Asymptomatic & $D s$ \\
\hline PA & Nockamixon State Park & N1-1GR & $\mathrm{PO}$ & $\mathrm{D}$ & 1 & 1 & Asymptomatic & $D c$ \\
\hline $\mathrm{PA}$ & Nockamixon State Park & N1-1GS & $\mathrm{PO}$ & $\mathrm{D}$ & 1 & 1 & Symptomatic & $D c$ \\
\hline PA & Nockamixon State Park & N1-7D & $\mathrm{PO}$ & $\mathrm{CD}$ & 1 & 1 & Symptomatic & $D c$ \\
\hline $\mathrm{PA}$ & Nockamixon State Park & $\mathrm{N} 18-11 \mathrm{H}$ & $\mathrm{PO}$ & $\mathrm{CD}$ & 1 & 1 & Asymptomatic & $D c$ \\
\hline PA & Nockamixon State Park & N19-6F & $\mathrm{PO}$ & $\mathrm{CD}$ & 1 & 4 & Asymptomatic & $D c$ \\
\hline PA & Tuscarora State Forest & TP24-12B & RO & I & 1 & 1 & Symptomatic & $D c$ \\
\hline PA & Tyler State Park & $\mathrm{T} 17-5 \mathrm{~A}$ & RO & $\mathrm{D}$ & 1 & 1 & Asymptomatic & $D s$ \\
\hline PA & Tyler State Park & T5-11F & RO & $\mathrm{D}$ & 1 & 0 & Asymptomatic & $D c$ \\
\hline PA & Nockamixon State Park & N1-1E & $\mathrm{PO}$ & $\mathrm{D}$ & 1 & 1 & Asymptomatic & $D c$ \\
\hline $\mathrm{VA}$ & Appomattox-Buckingham State Forest & $\mathrm{AB} 7-1 \mathrm{E}$ & RO & $\mathrm{U}$ & 5 & 1 & Asymptomatic & $D c$ \\
\hline VA & Conway Robinson State Forest & CR2-8B & RO & $\mathrm{U}$ & 1 & 1 & Symptomatic & $D c$ \\
\hline VA & Four Mile Creek Park & FM10-10D & TO & $\mathrm{CD}$ & 1 & 0 & Asymptomatic & $D c$ \\
\hline VA & Glenn Maury Park & FMB17-140 & TO & $\mathrm{CD}$ & 2 & 1 & Asymptomatic & $D c$ \\
\hline VA & Glenn Maury Park & GMB26-2d & RO & $\mathrm{CD}$ & 2 & 1 & Symptomatic & $D c$ \\
\hline WV & Audra State Park & $\mathrm{A} 10-11 \mathrm{E}$ & $\mathrm{CO}$ & $\mathrm{I}$ & 4 & 0 & Asymptomatic & $D c$ \\
\hline WV & \begin{tabular}{|l} 
Audra State Park \\
\end{tabular} & $\mathrm{A} 10-16 \mathrm{C}$ & WO & $\mathrm{D}$ & 2 & 1 & Asymptomatic & $D c$ \\
\hline WV & Beech Fork Lake Wildlife Management Area & BF16-12C & RO & $\mathrm{I}$ & 5 & 4 & Symptomatic & $B d$ \\
\hline WV & Beech Fork Lake Wildlife Management Area & BF16-12E & RO & $\mathrm{I}$ & 5 & 4 & \begin{tabular}{|l|} 
Symptomatic \\
\end{tabular} & $B d$ \\
\hline WV & Burnsville Lake Wildlife Management Area & B5-5E & WO & $\mathrm{D}$ & 2 & 0 & Asymptomatic & $D s$ \\
\hline WV & Conway Robinson State Forest & CR2-8G & RO & $\mathrm{U}$ & 1 & 1 & Symptomatic & $D c$ \\
\hline WV & East Lynn Wildlife Management Area & EL2-11A & $\mathrm{CO}$ & $\mathrm{CD}$ & 1 & 1 & Asymptomatic & $D q$ \\
\hline
\end{tabular}




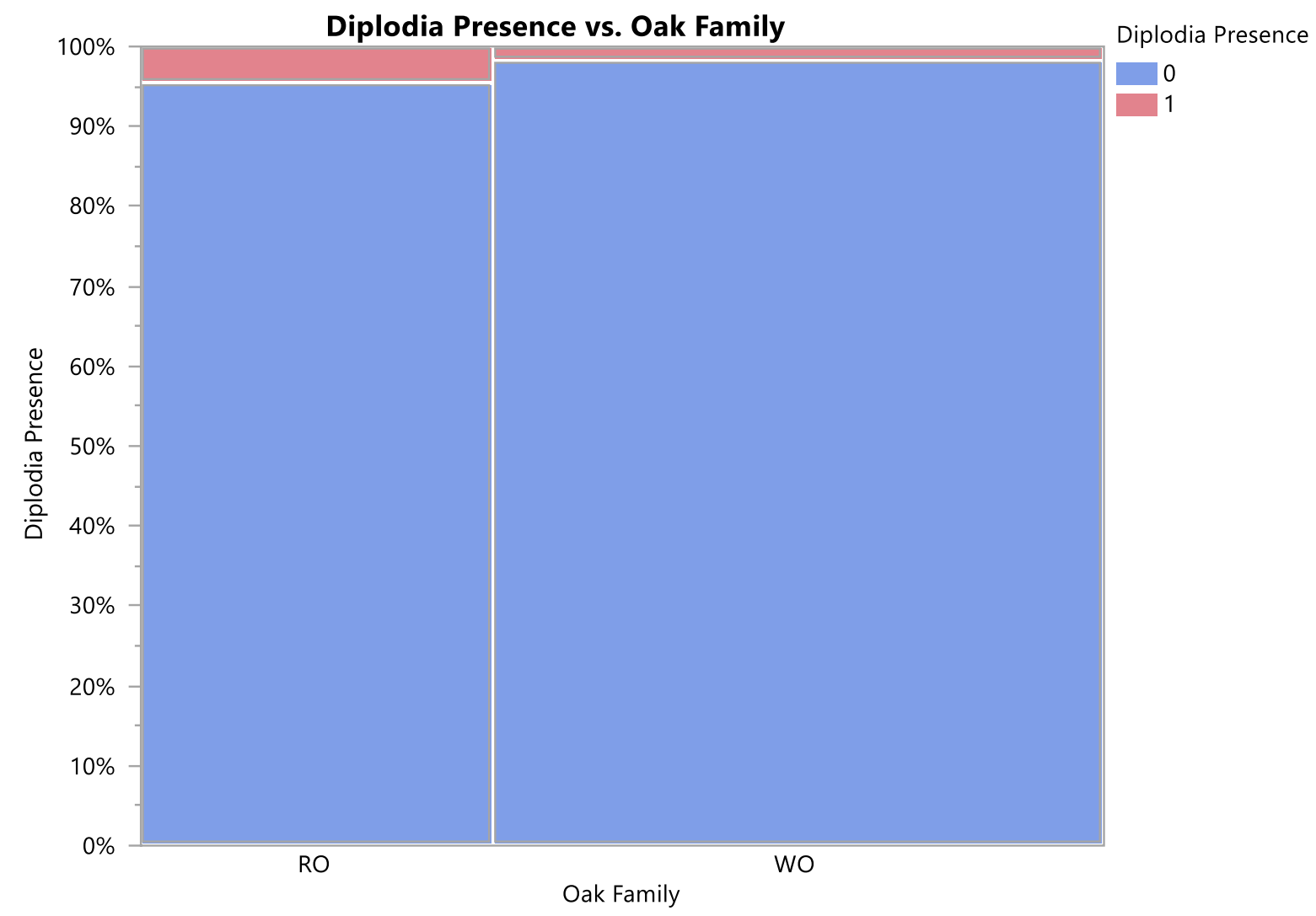

Figure 11: Mosaic plot showing Diplodia presence vs. oak family. Data are separated by symptom class $(0=$ Diplodia negative $(\mathrm{n}=986), 1=$ Diplodia positive $(\mathrm{n}=28))$ and oak family $(\mathrm{RO}=$ red oak family members $(\mathrm{n}=191), \mathrm{WO}=$ white oak family members $(\mathrm{n}=372))$. 
Table 8: Summary statistics for Diplodia presence by oak family. Data are separated by symptom class $(0=$ Diplodia negative $(\mathrm{n}=986), 1=$ Diplodia positive $(\mathrm{n}=28))$ and oak family $(\mathrm{RO}=$ red oak family members $(\mathrm{n}=191), \mathrm{WO}=$ white oak family members $(\mathrm{n}=372))$.

\begin{tabular}{|c|c|c|c|}
\hline \multicolumn{4}{|c|}{ Diplodia Presence } \\
\hline \begin{tabular}{|l|} 
Count \\
Total $\%$ \\
Col $\%$ \\
Row $\%$ \\
\end{tabular} & 0 & 1 & Total \\
\hline $\mathrm{RO}$ & 355 & 17 & 372 \\
\hline & 35.01 & 1.68 & 36.69 \\
\hline & 36.00 & 60.71 & \\
\hline & 95,43 & 4.57 & \\
\hline WO & 631 & 11 & 642 \\
\hline & 62.23 & 1.08 & 63.31 \\
\hline & 64.00 & 39.29 & \\
\hline & 98.29 & 1.71 & \\
\hline Total & 986 & 28 & 1014 \\
\hline & 97.24 & 2.76 & \\
\hline
\end{tabular}

Family is a significant predictor of Diplodia presence (chi-square $=6.827, \mathrm{p}$-value $=$ 0.0090), with red oak family members being more likely to have a Diplodia infection than white oak family members ( $\mathrm{p}$-value $=0.0076)$. Out of the 507 micro-sampled trees, 186 were red oak family members while 312 were white oak family members (Figure 11). Regardless of family, 493 of the sampled trees did not yield Diplodia spp. (Table 8). 


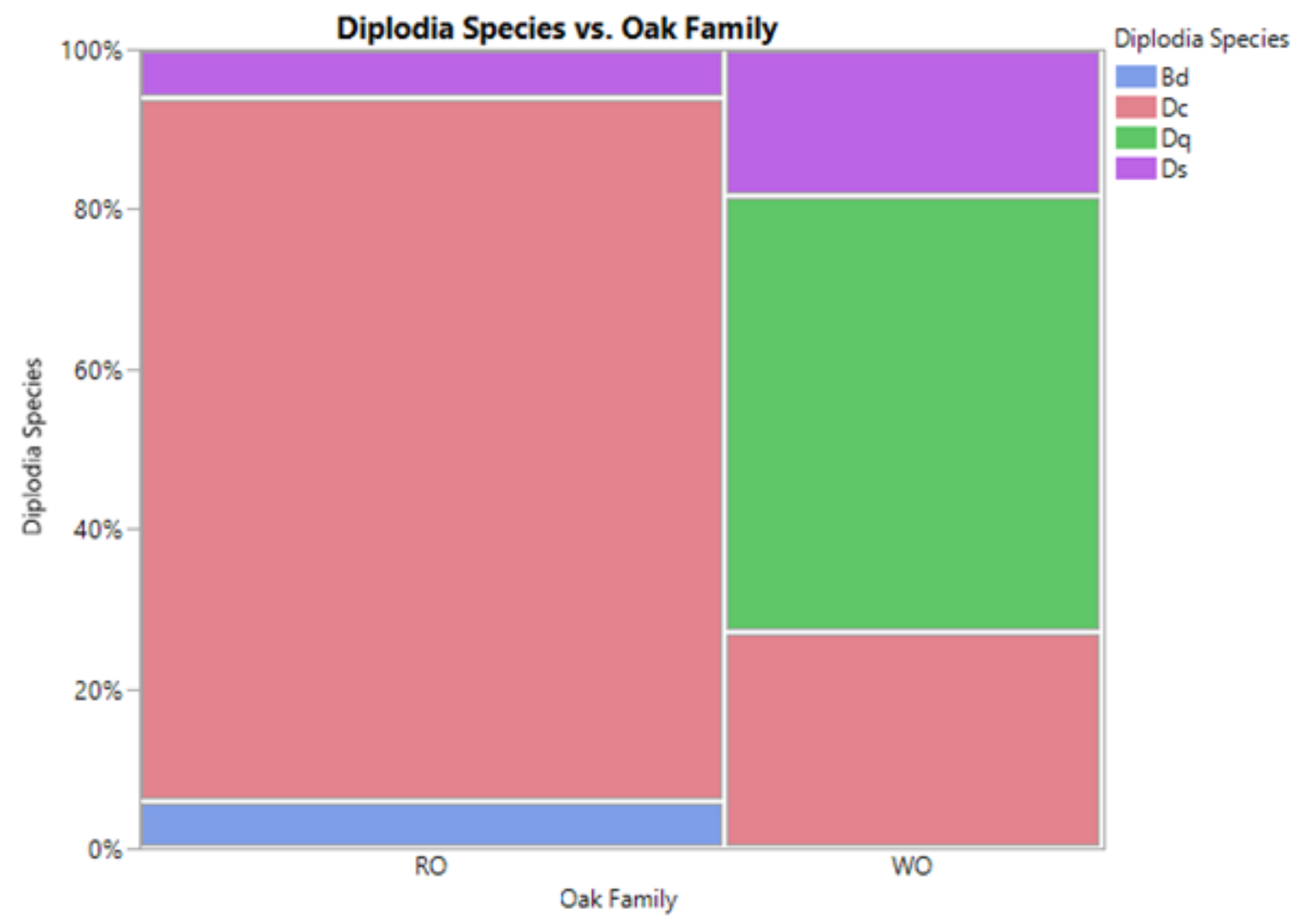

Figure 12: Mosaic plot showing Diplodia species vs. oak family. Data are separated by Diplodia species $(B d=$ Botryosphaeria dothidea $(\mathrm{n}=1)$, Dc $=$ Diplodia corticola $(\mathrm{n}=18)$, D $q=$ Diplodia quercivora $(\mathrm{n}=6)$, Ds = Diplodia sapinea $(\mathrm{n}=3))$ oak family $(\mathrm{RO}=$ red oak family members $(\mathrm{n}$ $=191)$, WO = white oak family members $(n=372)$ ).

Table 9: Summary statistics for Diplodia species by family for all Diplodia positive oak trees. Data are separated by Diplodia species $(B d=$ Botryosphaeria dothidea $(\mathrm{n}=1)$, Dc $=$ Diplodia corticola $(\mathrm{n}=18), D q=$ Diplodia quercivora $(\mathrm{n}=6)$, Ds = Diplodia sapinea $(\mathrm{n}=3))$ oak family $(\mathrm{RO}=$ red oak family members $(\mathrm{n}=191), \mathrm{WO}=$ white oak family members $(\mathrm{n}=372))$. 


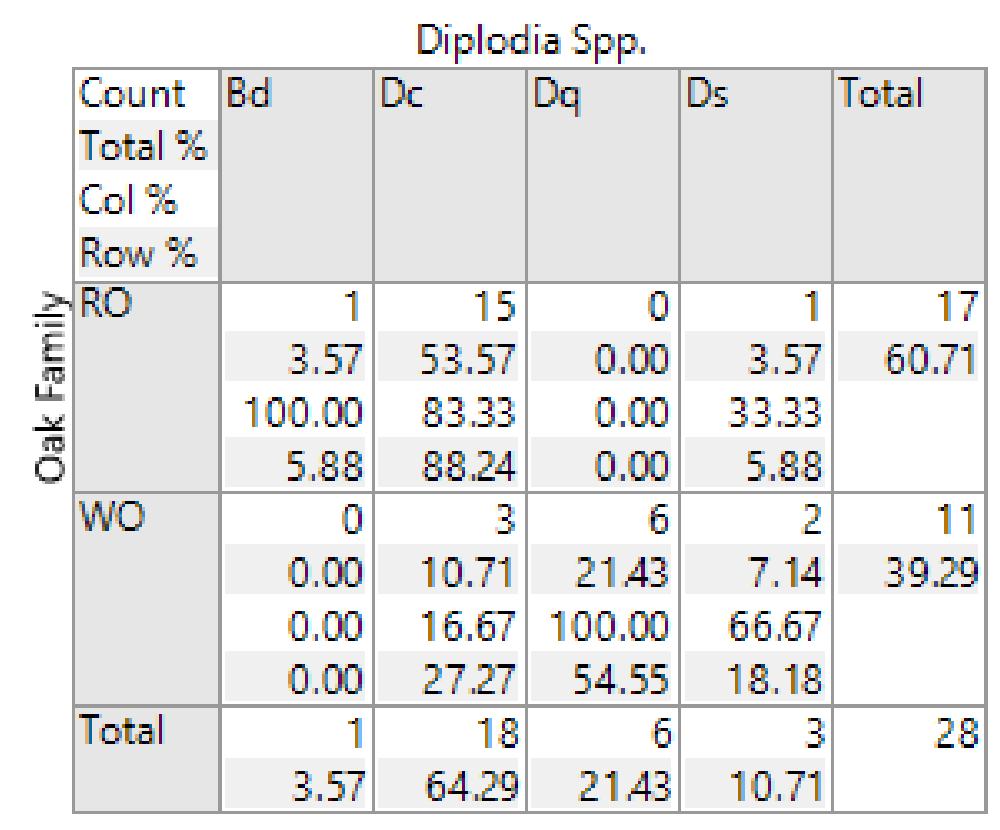

Oak family is a significant predictor of Diplodia species $($ chi-squared $=17.48, \mathrm{p}$-value $=$ 0.0006). Sampled red oak family members yielded 17 isolates $(60.71 \%)$ of Diplodia while white oak family members yielded 11 isolates (39.29\%) (Table 9). The highest recovered isolate was $D c(\mathrm{n}=18)$ with red oak family members having 15 isolates and white oak family members having three isolates. The second highest recovered species was $D q(\mathrm{n}=6)$ with all isolates recovered from white oak family members and no isolates recovered from red oak family members. The third most common isolate was $D s$ with three total isolates between both families, two from white oak and one from red oak family members. $B d$ was the least recovered species, with only one isolate from a red oak family member (Figure 12). Pathogenicity tests performed on 15 red oak seedlings failed to confirm $B d$ as a standalone pathogen of red oak, despite its recovery from symptomatic tissue (data not shown). 


\section{$\underline{\text { Inhibition Assay }}$}

The initial inhibition assay was assessed after one month. In the initial assay, radial growth of Diplodia was inhibited by both isolates of Penicillium (Figure 13A\&D) and one isolate of Pestalotiopsis (Figure 13F). Zone of inhibition was neither measured nor quantified however both fungi seemed to produce a notable inhibition zone ahead of the advancing margin. Diplodia inhibited the growth of both selected isolates of Trichoderma (Figure 13B\&E). The other isolate of Pestalotiopsis (Figure 13C) had no notable interaction with Diplodia.

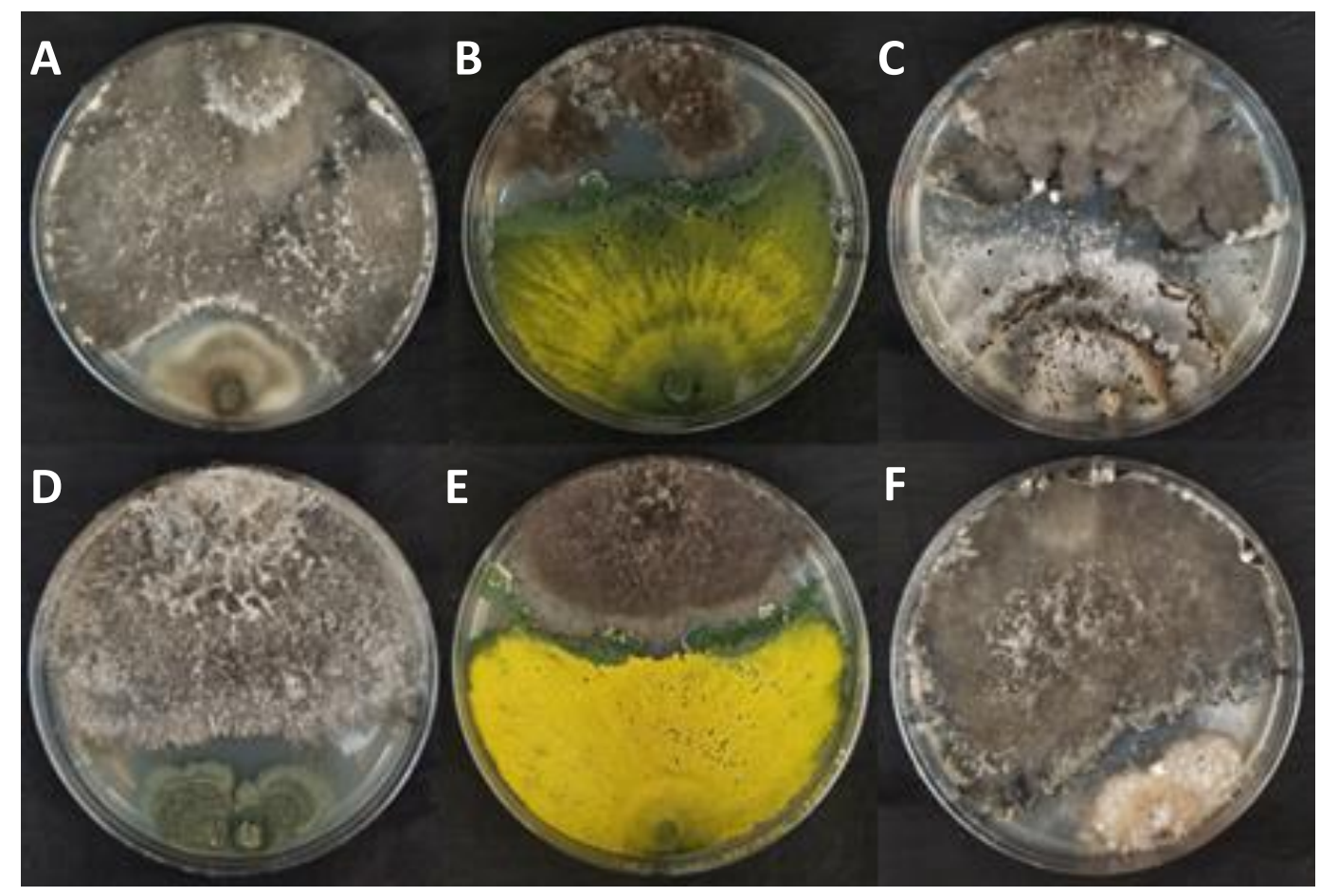

Figure 13: Initial fungal inhibition assay. A) Inhibition of $D q$ by Penicillium, B \&E ) Inhibition of Trichoderma by $D c$, C) Tie between $D c$ and Pestalotiopsis, D) Inhibition of Dc by Penicillium, F) Inhibition of Dc by Pestalotiopsis.

In the second inhibition assay, paired isolates were permitted to grow for one month, after which they were assessed. At one-week post pairing, all paired Diplodia spp. were able to inhibit 
the growth of all Trichoderma. At two weeks, all isolates of Diplodia were inhibited by all isolates of Penicillium (Figure 14D-F) and Pestalotiopsis (Figure 14A-C).

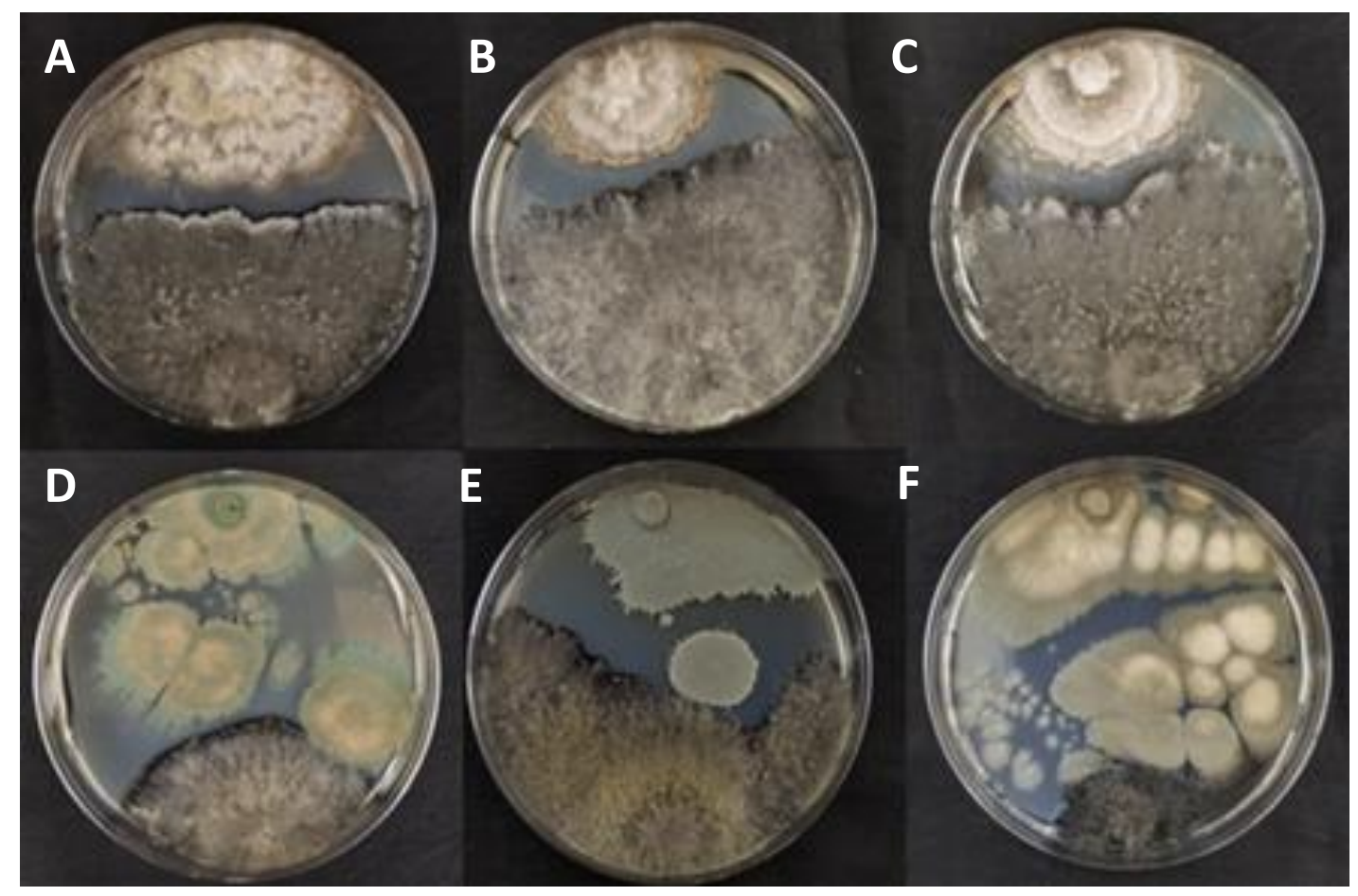

Figure 14: Follow-up fungal inhabition assay. A - C) Inhibition of Dc by Pestalotiopsis, D \&E) Inhibition of $D q$ by Penicillium, F) Inhibition of $B d$ by Penicillium.

\section{$\underline{\text { Phylogenetics }}$}

A total of 35 isolates were included in the single-gene and concatenated datasets subjected to phylogenetic analysis. Three isolates were served as either ingroup or outgroup reference strains including Dq isolate DQ703 (Haines et al. 2019), Dc isolate DC103 (Martin et al. 2017) and Botryosphaeria fusispora (Slippers et al. 2013). The three-gene concatenated dataset resolved all Diplodia species recovered, except for $B d$, into a monophyletic group with two major clades, one including $D c$ and $D q$ with a $73 \%$ bootstrap support and a second clade containing $D s$ with a $90 \%$ bootstrap support (Figure 15). The larger clade strongly supported $D q$ as a genealogically exclusive species with a 97\% bootstrap support. Among three single gene 
trees, three of the four Diplodia species, $D q, D s$, and $B d$ were genealogically exclusive in both ITS (Figure 16) and EF-1 $\alpha$ (Figure 17) trees. 


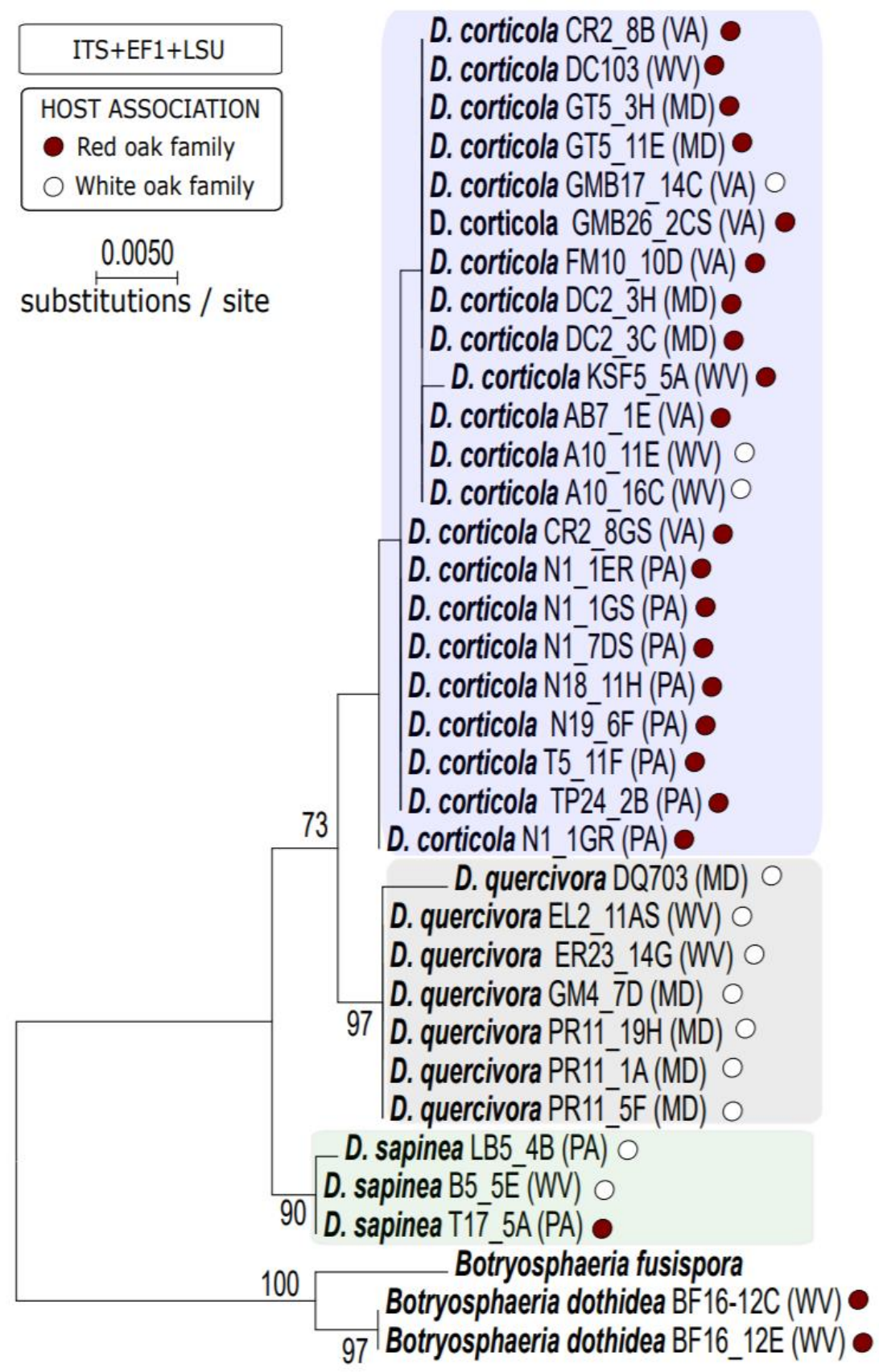

Figure 15: Phylogenetic tree showing ITS, EF-1 $\alpha$ and LSU gene regions for 35 analyzed isolates. For maximum likelihood analyses, a best fitting model was chosen using Model Selection analysis and 1,000 bootstrap replicates were used with the best tree being identified and bootstrapped in a single run. 


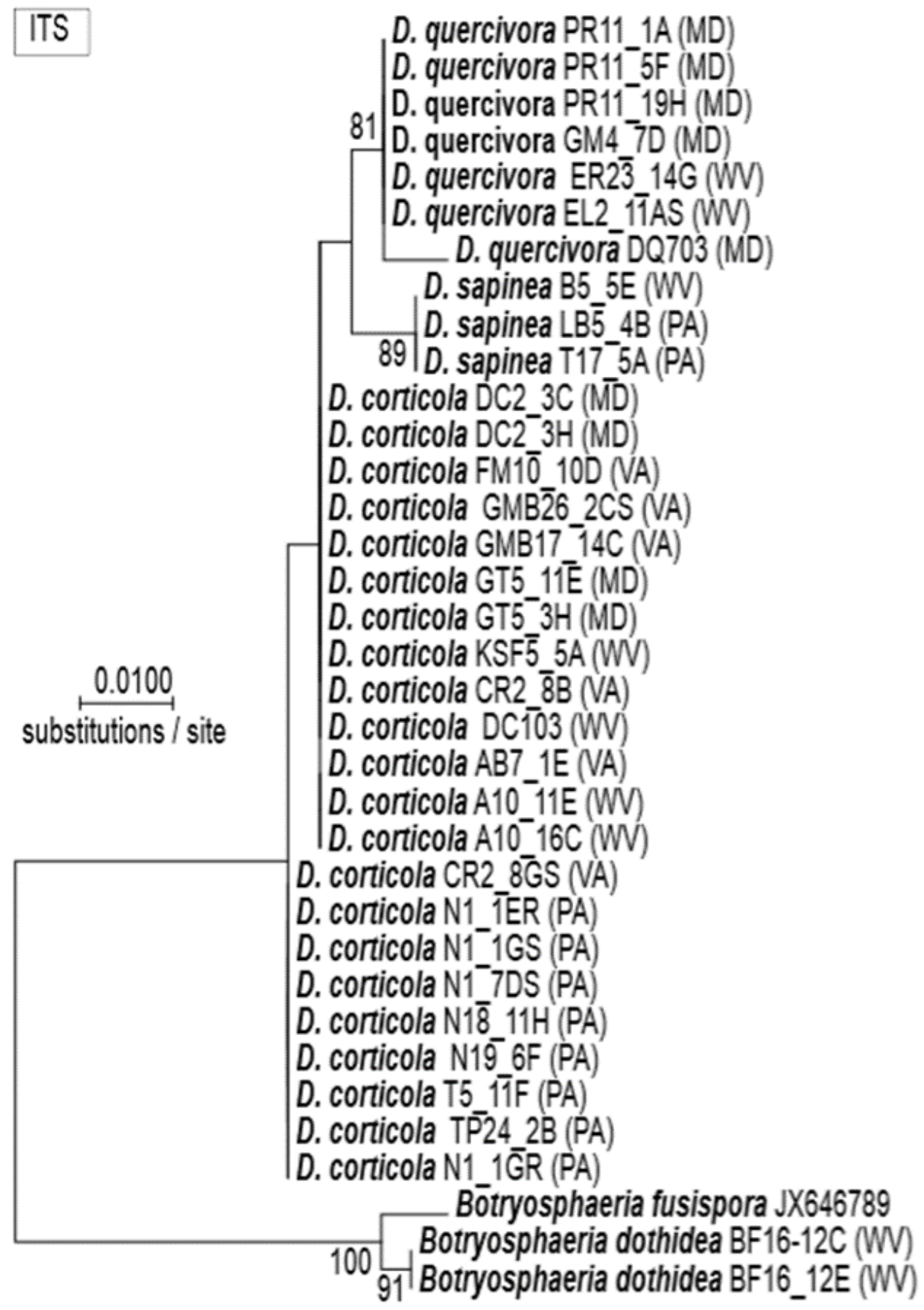

Figure 16: Phylogenetic tree showing ITS gene region for 35 analyzed isolates. For maximum likelihood analyses, a best fitting model was chosen using Model Selection analysis and 1,000 bootstrap replicates were used with the best tree being identified and bootstrapped in a single run. 


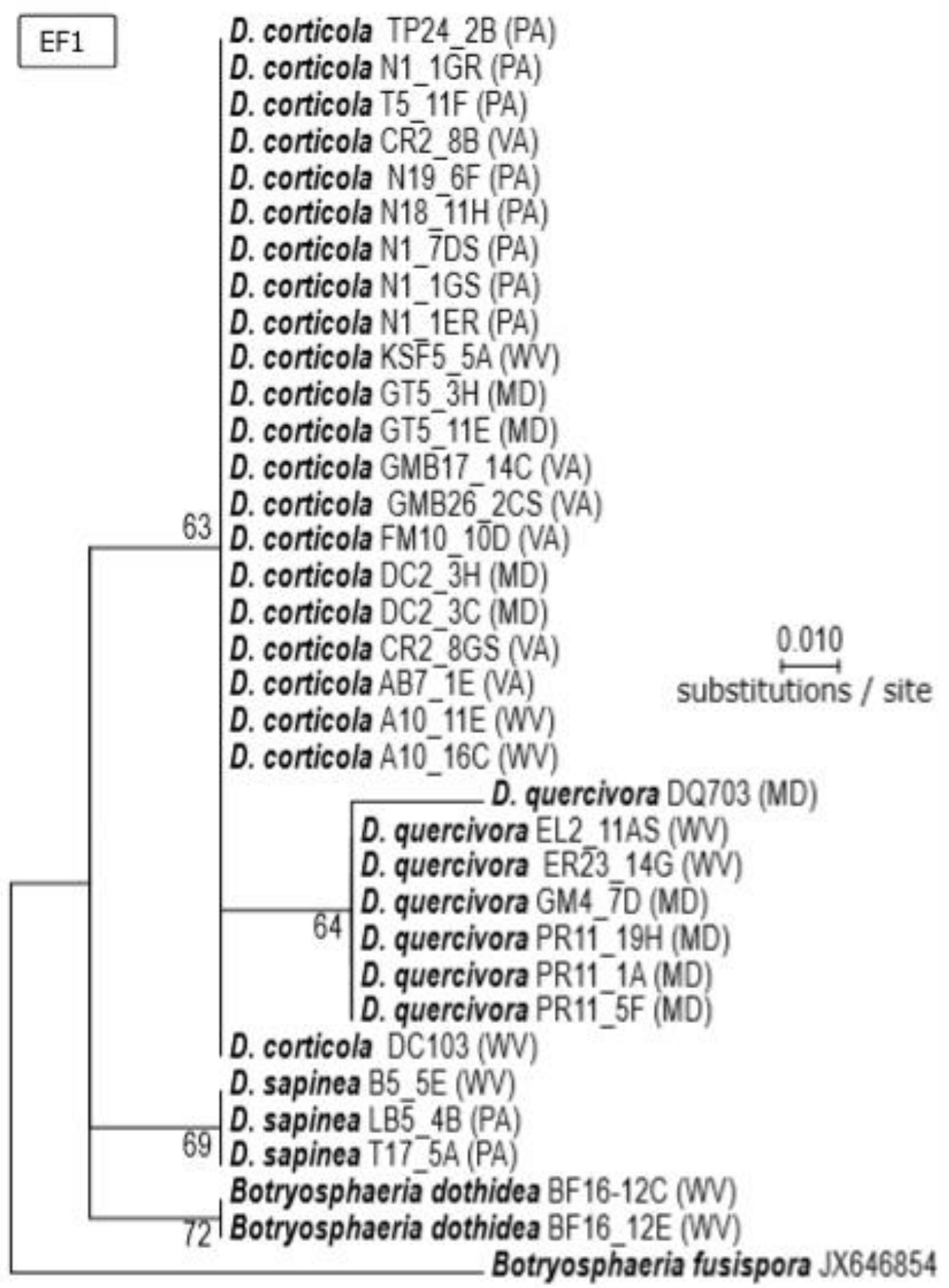

Figure 17: Phylogenetic tree showing EF-1 $\alpha$ gene region for 35 analyzed isolates. For maximum likelihood analyses, a best fitting model was chosen using Model Selection analysis and 1,000 bootstrap replicates were used with the best tree being identified and bootstrapped in a single run. 


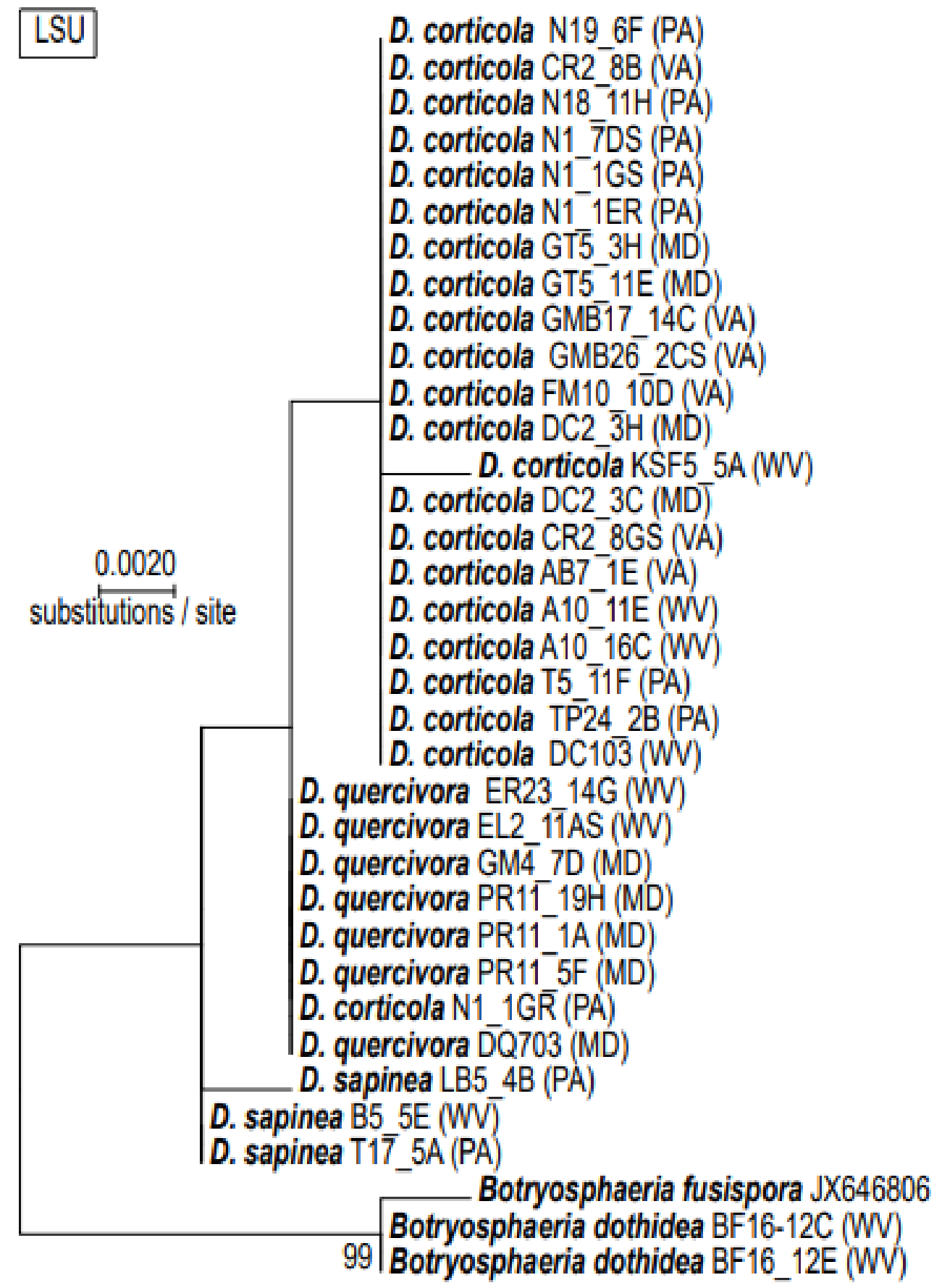

Figure 18: Phylogenetic tree showing LSU gene region for 35 analyzed isolates. For maximum likelihood analyses, a best fitting model was chosen using Model Selection analysis and 1,000 bootstrap replicates were used with the best tree being identified and bootstrapped in a single run. 


\section{$\underline{\text { Spore Production and Associated Measurements }}$}

Thirty isolates were plated on $1 / 10^{\text {th }}$ GYE under continuous light to induce sporulation. After four weeks, conidia were observed from 26 out of 30 Diplodia spp. isolates. Four isolates of $D q$ did not sporulate on this medium. Pycnidia were typically visible within two weeks of plating, with spores becoming visible within the following week. Observed spore sizes were significantly different by species ( $\mathrm{p}$-value $<0.0001$ ) and location ( $\mathrm{p}$-value $<0.0001)$.
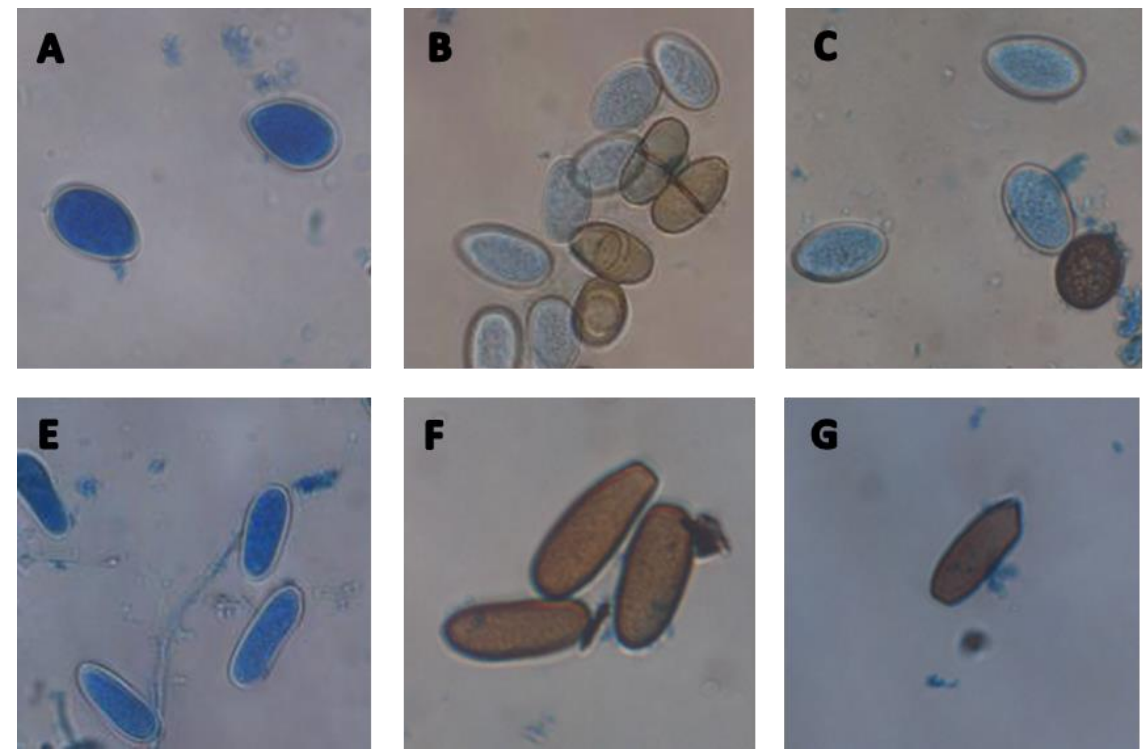
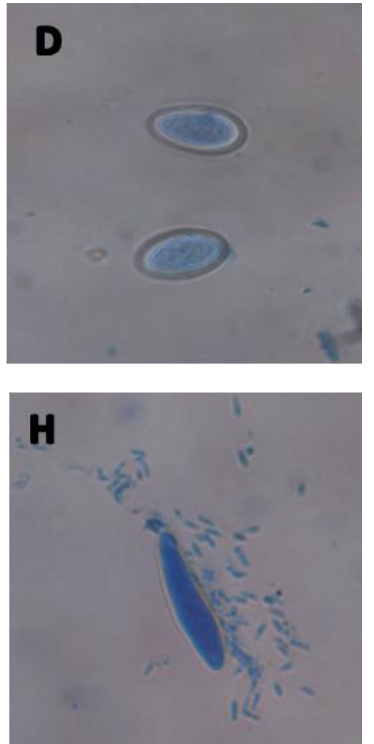

Figure 19: Morphological comparison of spores from $D c$ from A) MD, B) PA, C) VA and D) $\mathrm{WV} ; D q$ from E) MD; $D s$ from F) PA and G) WV; $B d$ from H) WV. Mountant is lactophenol + cotton blue. Spores shown at 40X magnification, not to scale.

Ds isolates had the smallest spore size across all observed Diplodia species, averaging $17.81 \mu \mathrm{m}$ with a standard deviation of $1.38 \mu \mathrm{m}$. These spores were observed as elliptical to oblong in shape and brown in color with no observed septations (Figure 19F\&G). For this species, spores from the WV were significantly larger $(\mathrm{p}$-value $<0.0002)$ than the spores 
observed from PA which measured 18.61 $\pm 0.25 \mu \mathrm{m}$ and $17.41 \pm 0.18 \mu \mathrm{m}$, respectively (Figure 20).

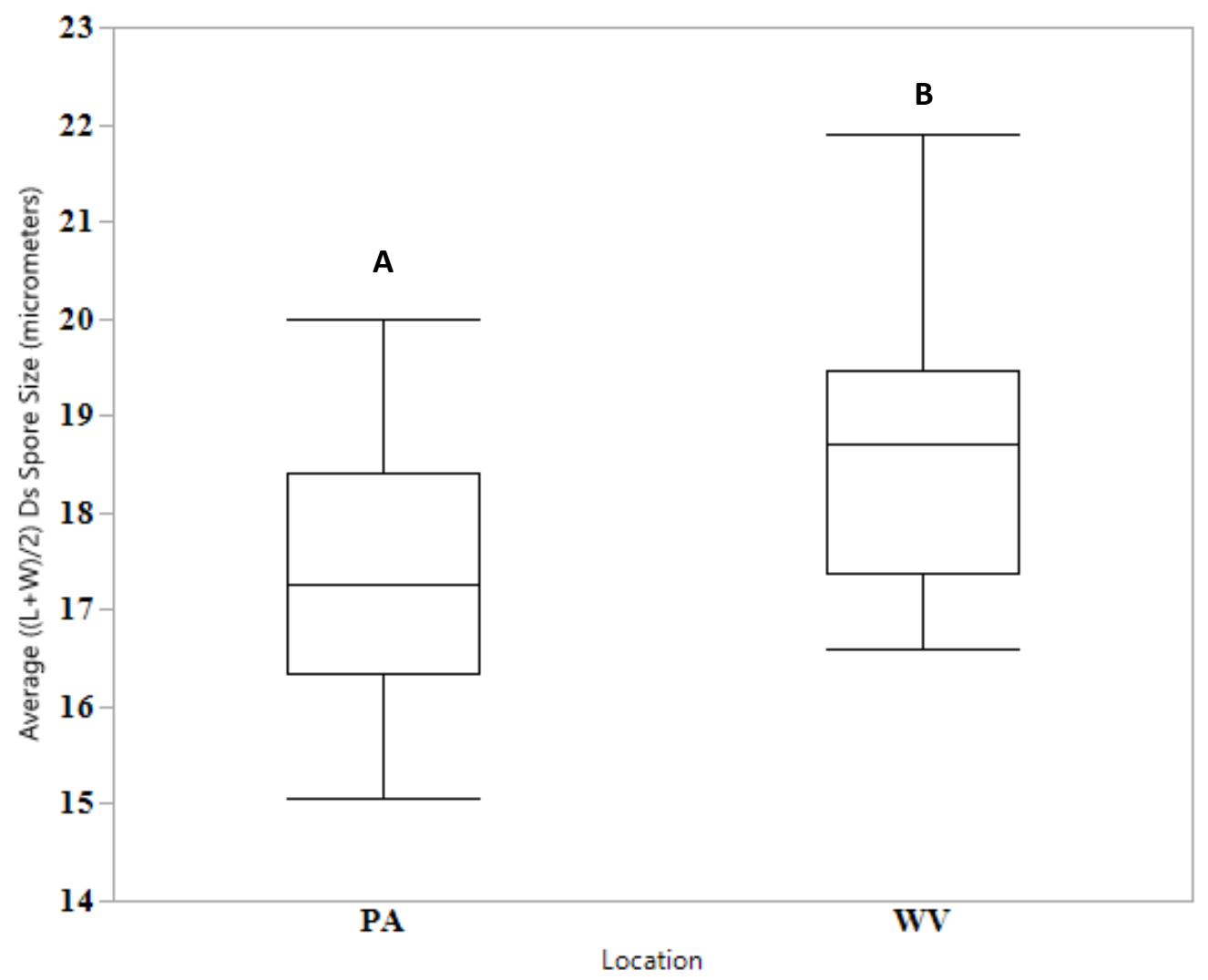

Figure 20: Box plots for average spore size ((Length One + Length Two $) / 2)$ of $D s$ isolates $(\mathrm{N}=$ $75)$ by location (state where isolate was obtained from PA $(n=2)$ and WV $(n=1))$. Spore sizes compared between species and among geographic location using ANOVA. Letter designation by Tukey Kramer's ordered letter report shows significant differences by location.

$D c$ isolates had the second smallest spore size among Diplodia spp. observed, averaging $19.33 \mu \mathrm{m}$ with a standard deviation of $1.65 \mu \mathrm{m}$. Among all isolates, $D c$ conidia were typically spherical to elliptical in shape and hyaline in color (Figure 19A-D). Frequently, spores were observed as a light to medium brown with a single septation (Figure 16B). Dc analyzed spores from VA were the largest $(20.18 \pm 0.12 \mu \mathrm{m})$, followed by WV $(19.73 \pm 0.17 \mu \mathrm{m}), \mathrm{MD}(19.47 \pm$ $0.15 \mu \mathrm{m})$ and PA $(18.34 \pm 0.11 \mu \mathrm{m})(\mathrm{p}$-value $<0.0001)($ Figure 21$)$. 


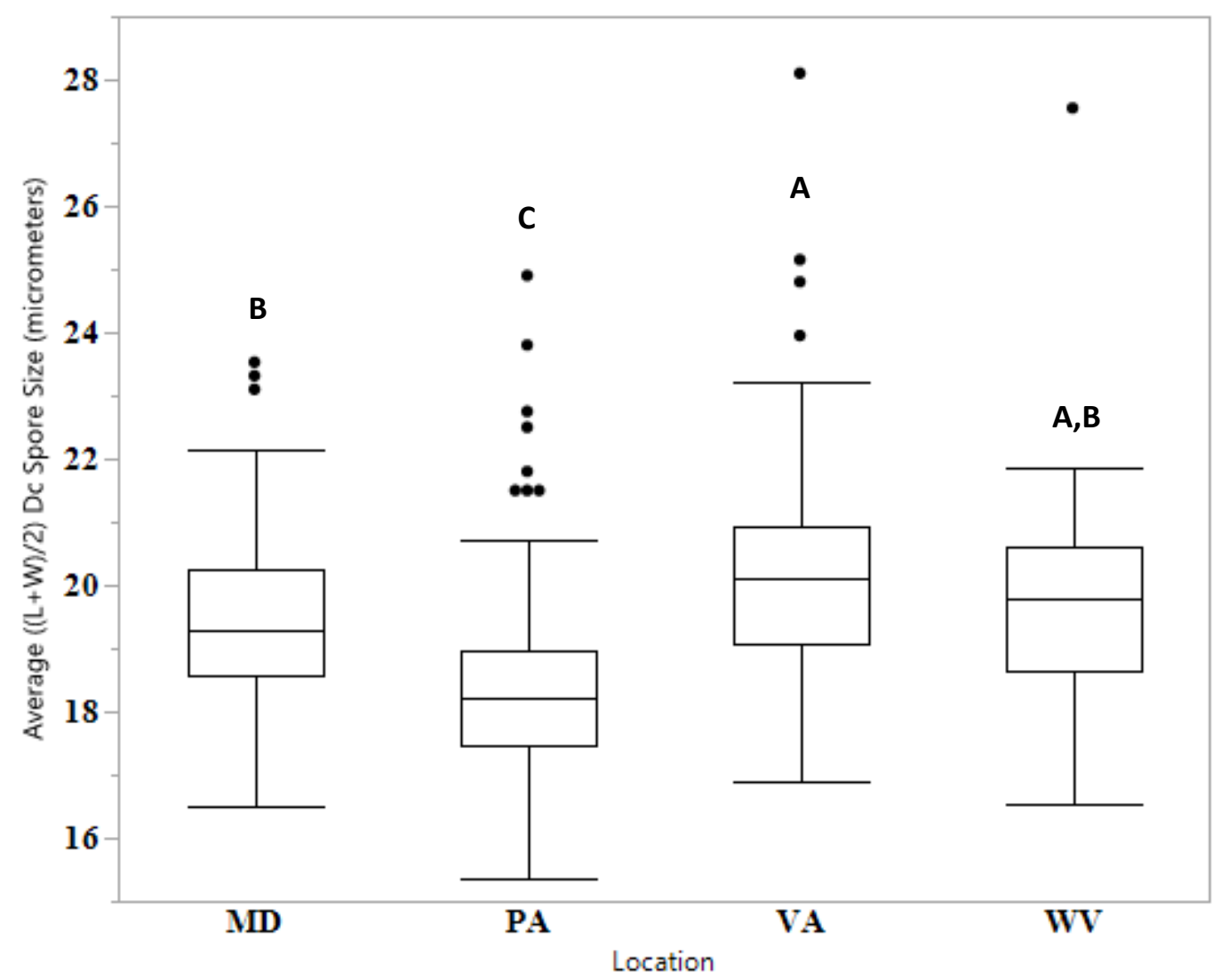

Figure 21: Box plots for average spore size ((Length One + Length Two)/2) of Dc $(\mathrm{N}=500)$ isolates by location (state where isolate was retained from MD $(n=4)$, PA $(n=7)$, VA $(n=6)$ and WV $(\mathrm{n}=3)$. Spore sizes compared between species and among geographic location using ANOVA. Letter designation by Tukey Kramer's ordered letter report shows significant differences by location. Single points outside the upper and lower extremes represent outliers and were included in analysis.

$D q$ had the second largest observed spores (Figure 19E), however due to $D q$ rarely producing pycnidia on $1 / 10^{\text {th }}$ agar, only two out of $\operatorname{six} D q$ isolates recovered during this study were analyzed. Both spore producing isolates were retained from $\mathrm{MD}$, so an analysis of spore size by location was not conducted. $D q$ spores averaged $19.81 \mu \mathrm{m}$ with a standard deviation of $1.29 \mu \mathrm{m}$. These spores were hyaline in color and elliptical to oblong in shape (Figure 19E).

These spores were not observed as being septate or pigmented. 
The largest observed conidia were from the single observed $B d$ isolate. This isolate also produced microconidia, but they were not measured in this study. The observed macroconidia averaged $25.69 \mu \mathrm{m}$ with a standard deviation of $3.68 \mu \mathrm{m}$. The macroconidia were long elliptical in shape and hyaline to brown in color (Figure 19H). Microconidia were also elliptical in shape and hyaline in color. No septations were observed in either micro or macroconidia. Due to the observation of a single $D d$ isolate, spore sizes were not compared by location.

\section{Colony Morphology Using Specialized Media}

When grown on modified pine needle extract agar, the previously identified Diplodia isolates lost their characteristic fluffy and irregular greyish-white growth and separated into several other distinctive morphotypes.

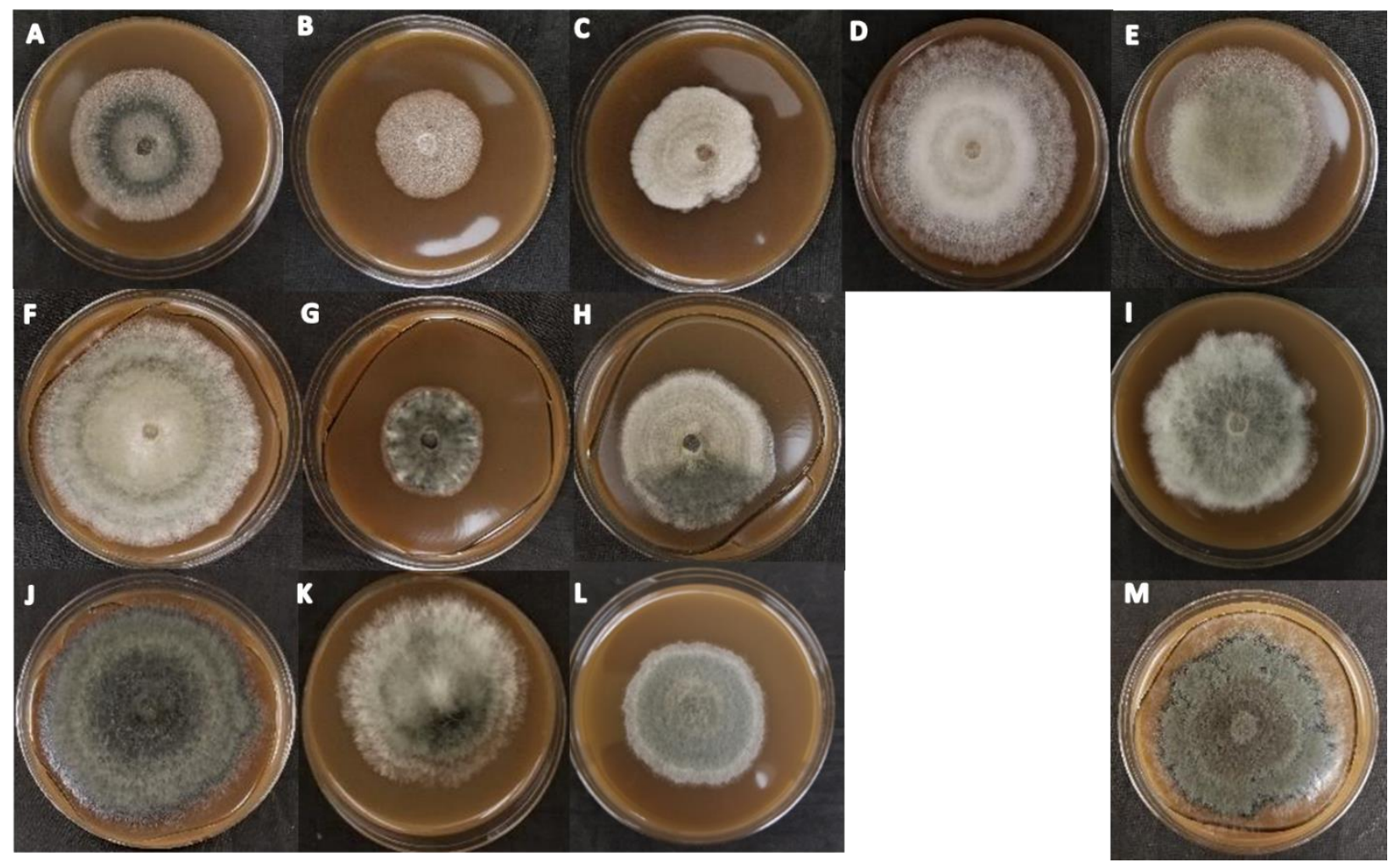

Figure 22: Representative Diplodia spp. isolates grown on pine needle extract agar for two weeks. Dc morphology A) morphotype 1, B) morphotype 2, C) morphotype 3, D) morphotype 4, E) morphotype 5, F) morphotype 6, G) morphotype 7, H) morphotype 8; Dq morphology I) 
morphotype 1; Ds morphology J) morphotype 1, K) morphotype 2, L) morphotype 3; $B d$ morphology M) morphotype 1.

$D c$ isolates separated into eight morphotypes: 1) green colonies with defined pink margins with aerial mycelium (Figure 22A) from eight isolates from all states; 2) pink colonies with smooth margins lacking aerial mycelium (Figure 22B) from two isolates obtained from VA; 3) predominately white colony with a light green hue with rosetted margins (Figure 22C) from one isolate from MD; 4) entirely white colony that has targeted growth and aerial mycelium (Figure 22D) from one isolate obtained from WV; 5) tufted green colony with white margins (Figure 22E) from three isolates obtained from PA, MD and WV; 6) green colonies with white margins and aerial mycelium throughout colony (Figure 22F) from three isolates obtained from PA; 7) small, dark blue and green colony with irregular margins (Figure 22G) from three isolates obtained from WV and VA; and 8) mostly pink colony with smooth margins lacking aerial mycelium with a darkened green septation (Figure $22 \mathrm{H}$ ) from one isolate obtained from VA.

$D q$ isolates had a single morphotype between the seven $D q$ isolates observed in MD and WV. These isolates had green colonies with irregular white margins and aerial mycelium (Figure 18I). Ds isolates had three different morphotypes: 1) green colony with a blue margin and aerial mycelium (Figure 18J) from one isolate from PA; 2) white and green colony with aerial mycelium and targeted growth (Figure 18K) from one isolate from WV; and 3) densely growing green colony with a defined white margin (Figure 18L) from one isolate from PA. Only one $B d$ isolate from WV was grown on PNE agar in this study, which resulted in a green colony with a blue margin and aerial mycelium (Figure 18M) from one isolate from WV. 


\section{Discussion:}

A regional survey was conducted in four states in the Mid-Atlantic region to observe the geographic distribution and level of damage caused by Diplodia spp. and explore their possible contributions to regional oak decline. The survey was overlaid across existing red oak mortality classes based upon regional USDA Forest Service FIA data, which provided a framework to capture the incidence and regional distribution of Diplodia across both red and white oak family members. The results of this study revealed that several species of Diplodia are present in the region, however their individual presence and damage varies by location and hosts.

In MD and VA, Dc was recovered for the first time from red oaks with several isolates of $D c$ recovered from turkey oaks in VA. In WV and PA, although already present, $D c$ was recovered for the first time on white and chestnut oak in WV, and for the first time on pin oak in PA. Although typically a fungal pathogen of two- or three-needled pines (Brodde et al. 2018, Rajotte 2017), Ds was recovered in this study from both chestnut and red oaks in PA and represents the first occurrence in WV on a white oak. Another fungal pathogen of numerous woody ornamental hosts (Turco et al. 2006, Sánchez et al. 2003), Bd was recovered for the first time from symptomatic red oak trees in WV. Isolates of $D q$, which had been only recently confirmed from MD, were recovered for the first time on chestnut oaks in WV.

The low numbers of Diplodia obtained from this survey may not accurately portray the incidence or impact this fungal canker pathogen is having in the region. This low recovery could be the result of sub-optimal sampling weather, inefficient sampling methods, and/or due to the randomized nature of field locations. In addition, heavy rain tends to mask the outward appearance of sooty lesions, which may have been overlooked due to the significant rainfall experienced in the 2019 sampling season. Regardless of weather conditions, Diplodia may have 
also been underrepresented due to heterogeneous distribution of fungal mycelium within asymptomatic host tissues, and/or extracting plugs that were colonized by Diplodia-inhibiting fungi. Using randomized sampling locations may have had the most drastic effect on recovered Diplodia spp. by potentially missing Diplodia positive trees. In both Seneca State Forest and Green Ridge State Forest, Diplodia was isolated and reported as being the causal agent of the observed decline (Haines et al. 2019, Martin et al. 2017). Upon resampling of those forests using the methods described in this paper, trees observed were in a separate geographic location in the forest and were Diplodia negative. Had the randomized locations been in the same proximity of the initial sampling, there may have been different results. Follow-up studies may provide insights into the size of outbreaks and abiotic and biotic factors that influence them.

Diplodia-positive trees were both outwardly asymptomatic and symptomatic, with symptomatic trees having dieback and/or bole symptoms. From the observations made in the field, symptomatic tissue was a significant predictor of dieback, however, they were not observed as large or frequent enough in this survey to cause large scale dieback or mortality. Based off our observations, white oak family members had fewer outward symptoms and had less isolated Diplodia spp. than the red oak family members.

Due to oak decline's history of other biotic complexes in addition to white oak family members' symptom development, it is possible that Diplodia spp. have been overlooked as causal agents of other recent declines including Rapid White Oak Mortality in states including Illinois, Iowa and Missouri (Reed et al. 2017).

When Diplodia penetrates the vascular cambium, tree response occurs in three tandem directions, vertically, radially and tangentially to wall off and stop the spread of the pathogen 
(Shortle 1979). White oak family members may be responding faster to Diplodia infections due to the utilization of tyloses in compartmentalization, which act as an additional response to wall off the vascular tissue (De Micco et al 2016, Meier 2008). This leads to the observation that when Diplodia is present, dieback is a better indicator of colonization in white oak family members, while outward symptom presence is a better indicator of colonization in red oak family members.

Diplodia spp. have been found in comparable numbers across 13 out of 18 counties and is present in all FIA mortality classes sampled. Although observed in a wide range of locations, this pathogen had low recovery across the region. Areas of high FIA reported mortality and observed dieback such a Gambrill State Park in Fredrick County (red), MD, had the same incidence of Diplodia as low FIA reported mortality stands such as Kumbrabow State Forest in Randolph County (blue), WV, based on culture-based approaches.

Although low in counts, Diplodia retained during this study are phylogenetically similar, although their geographic locations differ. These observations support the hypothesis that $D c$ is a native pathogen in the region and may be acting opportunistically in these sites. If this was an introduced or invasive pathogen, this survey should have resulted in higher associated mortality and retention of Diplodia spp.

\section{Conclusion:}

Diplodia corticola and Diplodia quercivora are opportunistic pathogens of oak trees and are likely contributing to broad scale oak decline in the Mid-Atlantic region, although their individual contributions remain unresolved. This survey showed that Diplodia spp. are more 
geographically widespread and associated with more oak hosts than previously reported.

Although capable of causing disease, Diplodia spp. were not observed as the inciting agent of ongoing large-scale mortality events in the sampled areas, although their role in previous mortality events at these sites could not be assessed. This study broadens the understanding of Diplodia distribution and its ecology, with evidence supporting $D c$ as native pathogen to this region. 


\section{References:}

Aćimović, S.G., Harmon, C.L., Bec, S., Wyka, S., Broders, K. and Doccola, J.J., 2016. First report of Diplodia corticola causing decline of red oak (Quercus rubra) trees in Maine. Plant Disease, $100(3)$, p.649.

Alves, A., Correia, A., Luque, J. and Phillips, A., 2004. Botryosphaeria corticola, sp. nov. on Quercus species, with notes and description of Botryosphaeria stevensii and its anamorph, Diplodia mutila. Mycologia, 96(3), pp.598-613.

Amos, R.E. and True, R.P., 1967. Longevity of Ceratocystis fagacearum in roots of deep-girdled oak-wilt trees in West Virginia. Phytopathology, 57(10), pp.1012-+.

Asaro, C. and Chamberlin, L.A., 2015. Outbreak history (1953-2014) of spring defoliators impacting oak-dominated forests in Virginia, with emphasis on gypsy moth (Lymantria dispar L.) and fall cankerworm (Alsophila pometaria Harris). American Entomologist, 61(3), pp.174185.

Bostock, R.M., Pye, M.F. and Roubtsova, T.V., 2014. Predisposition in plant disease: exploiting the nexus in abiotic and biotic stress perception and response. Annual review of phytopathology, 52, pp.517-549.

Brodde, L., Adamson, K., Julio Camarero, J., Castaño, C., Drenkhan, R., Lehtijärvi, A., Luchi, N., Migliorini, D., Sánchez-Miranda, Á., Stenlid, J. and Özdağ, Ş., 2019. Diplodia tip blight on its way to the north: drivers of disease emergence in Northern Europe. Frontiers in plant science, 9 , p.1818.

Dreaden, T.J., Shin, K. and Smith, J.A., 2011. First report of Diplodia corticola causing branch cankers on live oak (Quercus virginiana) in Florida. Plant disease, 95(8), pp.1027-1027.

Haines, S.L., Stauder, C.M., Martin, D.K.H., Thompson, B.A. and Kasson, M.T., 2019. First Report of Diplodia quercivora Causing Stem Cankers on Chestnut Oak (Quercus montana) in Maryland. Plant Disease, 103(6), p.1423.

Jacobi, W.R. and MacDonald, W.L., 1980. Colonization of resistant and susceptible oaks by Ceratocystis fagacearum. Phytopathology, 70(7), pp.618-623.

Kumar, S., Stecher, G. and Tamura, K., 2016. MEGA7: molecular evolutionary genetics analysis version 7.0 for bigger datasets. Molecular biology and evolution, 33(7), pp.1870-1874.

Lazzizera, C., Frisullo, S., Alves, A. and Phillips, A.J.L., 2008. Morphology, phylogeny and pathogenicity of Botryosphaeria and Neofusicoccum species associated with drupe rot of olives in southern Italy. Plant Pathology, 57(5), pp.948-956.

Linaldeddu, B.T., Maddau, L. and Franceschini, A., 2017. First Report of Diplodia corticola Causing Canker and Dieback of Quercus ilex, Q. petraea, and Q. suber in Corsica (France). Plant Disease, 101(1), pp.256-256. 
Lynch, S.C., Eskalen, A., Zambino, P. and Scott, T., 2010. First report of bot canker caused by Diplodia corticola on coast live oak (Quercus agrifolia) in California. Plant disease, 94(12), pp.1510-1510.

Martin, D.K.H., Turcotte, R.M., Miller, T.M., Munck, I.A., Aćimović, S.G., Macias, A.M., Stauder, C.M. and Kasson, M.T., 2017. First report of Diplodia corticola causing stem cankers and associated vascular occlusion of northern red oak (Quercus rubra) in West Virginia. Plant Disease, 101(2), pp.380-380.

Martin Danielle, K., and Isabel Munck. "Northeastern Area State and Private Forestry." Pest Alert Diplodia Corticola "Bot Canker" of Oak NA-PR-01-17 | Northeastern Area State and Private Forestry, Apr. 2017, www.fs.usda.gov/naspf/publications/pest-alert-diplodia-corticola$\%$ E2\%80\%9Cbot-canker\%E2\%80\%9D-oak-na-pr-01-17.

McConnell, M.E. and Balci, Y., 2014. Phytophthora cinnamomi as a contributor to white oak decline in Mid-Atlantic United States forests. Plant disease, 98(3), pp.319-327.De Micco, V., Balzano, A., Wheeler, E.A. and Baas, P., 2016. Tyloses and gums: a review of structure, function and occurrence of vessel occlusions. IAWA journal, 37(2), pp.186-205.

Meier, Eric. "Holm Oak.” The Wood Database, 2008, www.wood-database.com/holm-oak/.

De Micco, V., Balzano, A., Wheeler, E.A. and Baas, P., 2016. Tyloses and gums: a review of structure, function and occurrence of vessel occlusions. IAWA journal, 37(2), pp.186-205.

Munck, I.A., Wyka, S.A., Bohne, M.J., Green, W.J. and Siegert, N.W., 2017. First report of Diplodia corticola causing bleeding cankers on black oak (Quercus velutina). Plant Disease, 101(1), p.257.

Oak, S.W., Spetich, M.A. and Morin, R.S., 2016. Oak decline in central hardwood forests: frequency, spatial extent, and scale. In Natural Disturbances and Historic Range of Variation (pp. 49-71). Springer, Cham.

Rajotte, Ed. “Diplodia (Sphaeropsis) Tip Blight.” Penn State Extension, 21 Nov. 2017, extension.psu.edu/diplodia-sphaeropsis-tip-blight.

Reed, S.E., English, J.T., Muzika, R.M., Kabrick, J.M. and Wright, S., 2017. Characteristics of sites and trees affected by rapid white oak mortality as reported by forestry professionals in Missouri. In In: Kabrick, John M.; Dey, Daniel C.; Knapp, Benjamin O.; Larsen, David R.; Shifley, Stephen R.; Stelzer, Henry E., eds. Proceedings of the 20th Central Hardwood Forest Conference; 2016 March 28-April 1; Columbia, MO. General Technical Report NRS-P-167. Newtown Square, PA: US Department of Agriculture, Forest Service, Northern Research Station: 240-247. (pp. 240-247).

Reed, S.E., English, J.T., Lalk, S.R. and Tosie, K.M., 2018. First report of Diplodia corticola causing stem and branch cankers on white oak (Quercus alba) in Missouri, USA. Plant disease, 102(12), p.2657. 
Sánchez, M.E., Venegas, J., Romero, M.A., Phillips, A.J.L. and Trapero, A., 2003. Botryosphaeria and related taxa causing oak canker in southwestern Spain. Plant disease, 87(12), pp.1515-1521.

Schomaker, M.E., Zarnoch, S.J., Bechtold, W.A., Latelle, D.J., Burkman, W.G. and Cox, S.M., 2007. Crown-condition classification: a guide to data collection and analysis. Gen. Tech. Rep. SRS-102. Asheville, NC: US Department of Agriculture, Forest Service, Southern Research Station. 78 p., 102.

Shigo, A.L., 1958. Fungi isolated from oak-wilt trees and their effects on Ceratocystis fagacearum. Mycologia, 50(5), pp.757-769.

Shortle, W.C., 1979. Mechanisms of compartmentalization of decay in living trees. Phytopathology, 69(10), pp.1147-1151.

Slippers, B., Boissin, E., Phillips, A.J.L., Groenewald, J.Z., Lombard, L., Wingfield, M.J., Postma, A., Burgess, T. and Crous, P.W., 2013. Phylogenetic lineages in the Botryosphaeriales: a systematic and evolutionary framework. Studies in Mycology, 76, pp.31-49.

Smith, D.R. and Stanosz, G.R., 2018. Occurrence of Diplodia corticola, including new oak host records, in Wisconsin, USA. Forest pathology, 48(4), p.e12427.

Tiberi, R., Branco, M., Bracalini, M., Croci, F. and Panzavolta, T., 2016. Cork oak pests: a review of insect damage and management. Annals of forest science, 73(2), pp.219-232.

Turco, E., Marianelli, L., Vizzuso, C., Ragazzi, A., Gini, R., Selleri, B. and Tucci, R., 2006. First report of Botryosphaeria dothidea on sycamore, red oak, and English oak in northwestern Italy. Plant disease, 90(8), pp.1106-1106.

Villesen, P., 2007. FaBox: an online toolbox for fasta sequences. Molecular ecology notes, 7(6), pp.965-968. 